\title{
تأثيز استخدام المهارات اليدوية الزخرفية والبنائية علي الإمكانات الجمالية لتصميم ملابس الأطفال
}

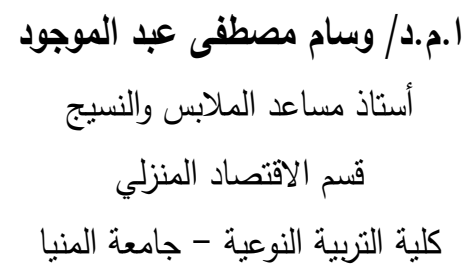

\author{
| ا.م.د/ سوزان على عبد الحميد علي \\ أسناذ مساعد الملابس والنسيج \\ قسم الاقتصاد المنزلي \\ كلية التربية النوعية - جامعة الفيوم
}

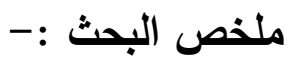

يهدف هذا البحث بصفة أساسية إلى التعرف على المهارات البدوبة المختلفة التي يمكن أن تُشتخدم لزخرفة ملابس الأطفال في مرحلة الطفولة المبكرة (س-0)، وتوضيح تأثير استخدام المهارات اليدوية المنفذة فى التصميم البنائي والزخرفي على كل من الجانب الجمالي والجانب الـوظيفي لملابـس الأطفال.كذلك مـن ضــن أهدافـه الوصـول بالدراسـة إلـى الأسـلوب الأمثنل

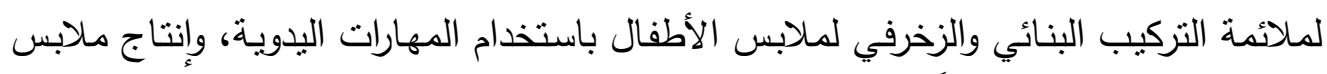
أطفال أقل تكلفة وأكثر تميزاً وقيمة جمالية عالية.

$$
\text { وكانت أدوات البحث عبارة عن :- }
$$

ا-ستمارة استبيان لأراء المحكمين نحو ملابس الأطفال المنفذة ومزخرفة بالمهارات اليدوية المختلفة، من إعداد الباحثنان.

ץ-استمارة استبيان لأراء المستهكات نحو ملابس الأطفال المنفذة ومزخرفة بالمهارات البدوية المختلفة، من إعداد الباحثثان.

واستخدمت البحث الحالي المنهج الوصفي التجريبي.فالمنهج الوصفي في وصف كل أسلوب من المهارات البدوية التي تم استخدامها للتصميم البنائي أو الزخرفي لملابس أطفال المرحلة المبكرة. أمـا المنهج التجريبي فتمثل في اختيار المهارات اليدوبية لإجراء تجارب لتتفيذ التهيذ ملابس أطفال المرحلة المبكرة لتحديد إمكانيـة استخدامها فى رفع الجانب الجمالي والوظيفي للقطع المنفذة.

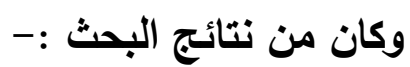
ا-توجد فروق ذات دلالـة إحصـائية بين المهارات الزخرفية للتصميمات الخمس في تحقيق القيم الجمالية وفقا لأراء المتخصصين. ץ-توجد فروق ذات دلالـة إحصـائية بين المهارات الزخرفيـة للتصميمات الخمس في تحقيق وفين القيم الوظيفية وفقا لأراء المتخصصين. 
ب-توجد فروق ذات دلالة إحصائية بين المهارات الزخرفية للتصميمات الخمس في ملاءمـة

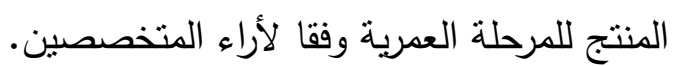

ع-توجد فروق ذات دلالة إحصائية بين المهارات الزخرفيـة للتصميمات الخمس وفقا لأراء

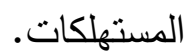

ه-توجد فروق ذات دلالة إحصائية بين المهارات البنائية للتصميمات الخمس في تحقيق القيم الجمالية وفقا لأراء المتخصصين.

צ-توجد فروق ذات دلالة إحصائية بين المهارات البنائية للتصميمات الخمس في تحقيق القيم الوظلفية وفقا لأراء المتخصصين.

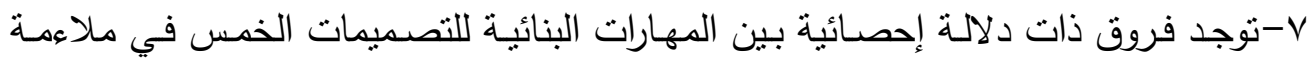

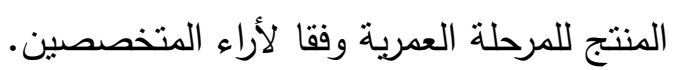

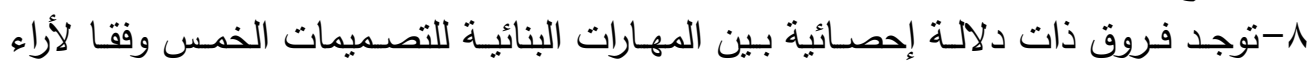
المستهكات.

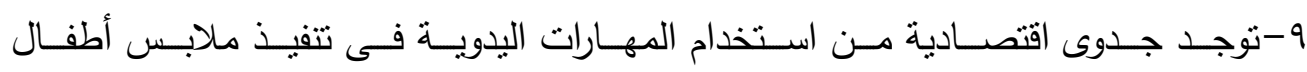
المرحلة المبكرة.

\section{The effect of the use of decorative and structural handicrafts on the aesthetic potential of children's clothing design}

\section{A.P.D}

Sozan Aly Abdulhameed Aly Assistant professor of clothing and textile department of Home Economics Faculty of Specific Education Faiuom Universit

\section{A.P.D}

Wessam Moustafa Abd El Mougoud

Assistant professor of clothing and textile department of Home Economics Faculty of Specific Education Minia University

\section{Research outline:-}

This research aims mainly at identifying the various handicraft skills that can be used to decorate children's clothing in early childhood (3-5), and to clarify the effect of the use of manual skills implemented in structural and decorative design on both aesthetic and functional aspects of children's clothing. The aim of this course is to study the best way to adapt the structural and decorative structure of children's clothing using manual skills, and to produce children's clothing that is less expensive, more distinguished and highly aesthetic.

The search tools were: -

1- A questionnaire for the referees' opinions about the children's clothing executed and decorated with different manual skills, prepared by the researchers. 
2- A questionnaire for the views of consumers towards children's clothing executed and decorated with different hand skills, prepared by the researchers.

The current research used descriptive descriptive method. The descriptive approach in describing each style of manual skills used for the structural or decorative design of early stage clothes. The experimental approach is the selection of manual skills to conduct experiments for the implementation of early stage clothes to determine the possibility of using them in raising the aesthetic and functional aspect of the executed pieces.

\section{The results of the research include:}

1- There are differences of statistical significance between the decorative skills of the five designs in the achievement of aesthetic values according to the views of specialists.

2- There are differences of statistical significance between the decorative skills of the five designs in the achievement of functional values according to the views of specialists.

3- There are differences of statistical significance between the decorative skills of the five designs in the suitability of the product for the age group according to the opinions of specialists.

4- There are differences of statistical significance between the decorative skills of the five designs according to the views of consumers.

5- There are differences of statistical significance between the structural skills of the five designs in the achievement of aesthetic values according to the views of specialists.

6- There are differences of statistical significance between the structural skills of the five designs in the achievement of functional values according to the views of specialists.

7- There are differences of statistical significance between the structural skills of the five designs in the suitability of the product for the age group according to the opinions of specialists.

8- There are differences of statistical significance between the structural skills of the five designs according to the views of consumers.

9- There is an economic feasibility of using manual skills in the implementation of early-stage clothing. 


\section{المقدمة والمشكلة البحثية:}

تعتبـر القيمـة الجماليـة مـن القيم الكبـرى التـي يسـعي المصـمم لتحقيقهـا مـن خــل

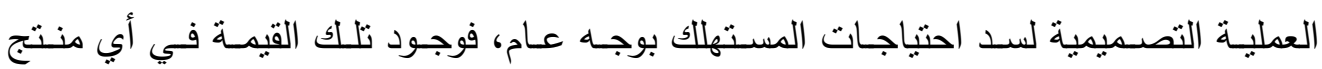

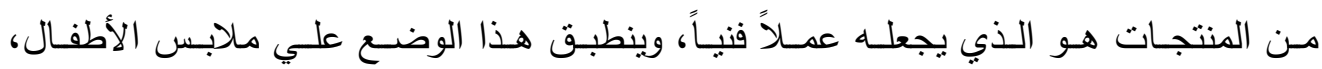

$$
\text { (بارق مصطفي، .... (ب). }
$$

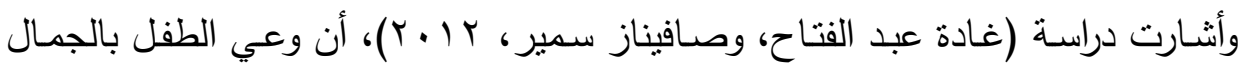

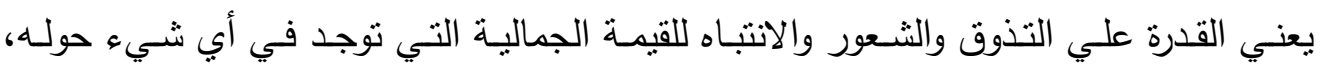
وتتاولت الدراسـة فن الكروشيه اليدوي والتريكو الآلكي والتطريز الآلكي لإثراء القيمـة الجماليـة لملابس الأطفال خلال مرحلة الطفولة المتوسطة، لتفعيل دور الصناعات الصغيرة باستخدام التقنيات المختلفة بهدف الإفادة منها في مجال سوق العمل، فمن الضروري الارتقاء بالقيمة

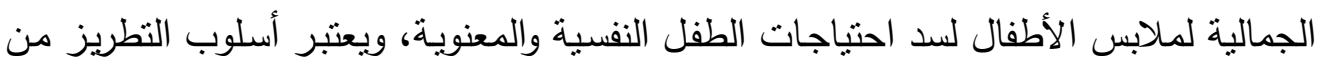

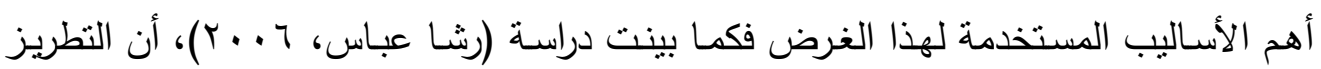

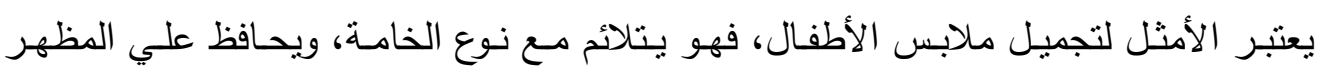

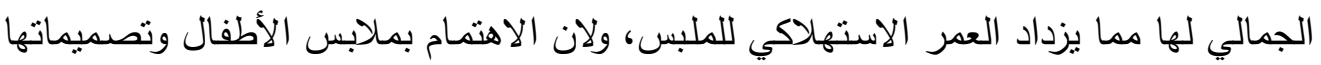

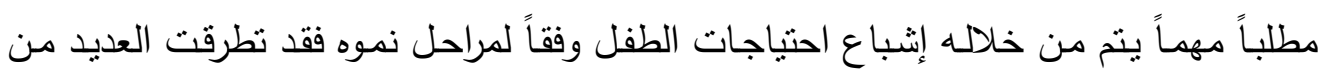

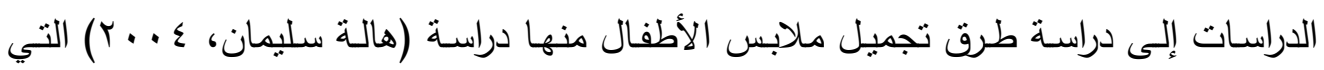
تتاولت أسـاليب التطريز المستخدمة في ملابس الأطفال، والطرق المختلفة لتنفيذها، وكـان

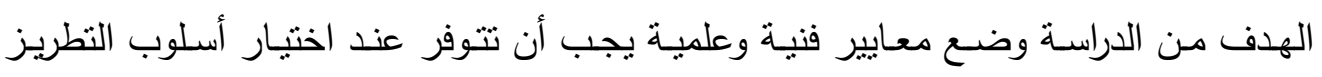

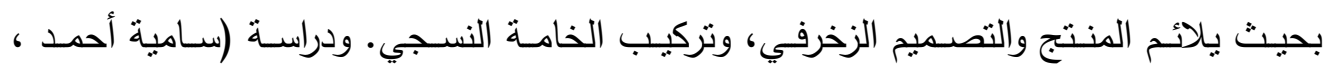

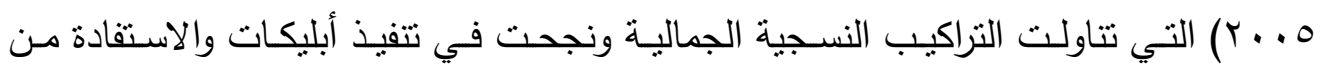
تأثيراتها في إضافات ملمسيه على سطح ملابس الأطفال، وتوصلت بالنتائج إلي أن التراكيب النسجية تتميز بملامس وألوان متتوعة تتاسب خصائص نمو الطفل، كما تثري القيم التشكيلية

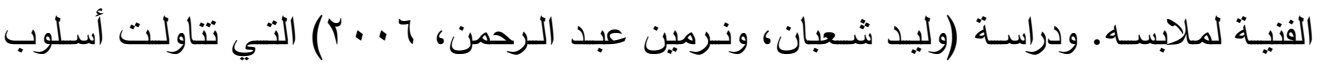

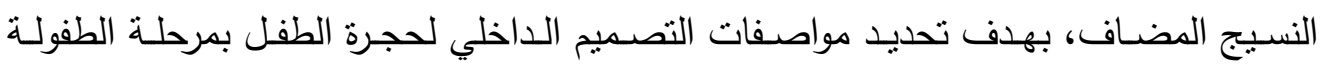

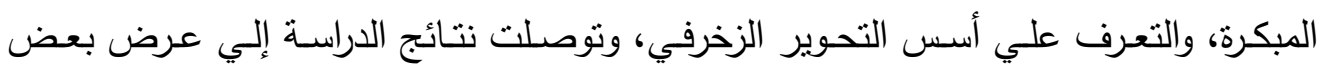

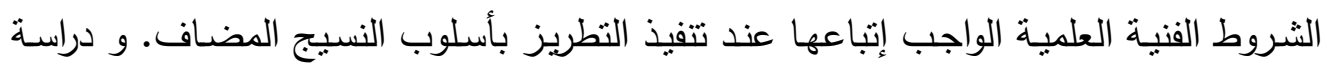

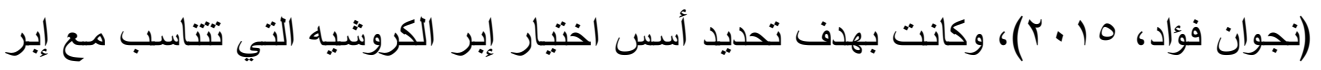


التريكو وأنـواع الخيوط المتاحـة في السـوق المصـري، وقد تـم تصـميم وتتفيـذ مجموعـة مـن الملابس ومكملاتها للأطفال تجمع بين الكروشيه والتريكو اليدوي، وتوصلت نتائج الدراسة إلي وفي

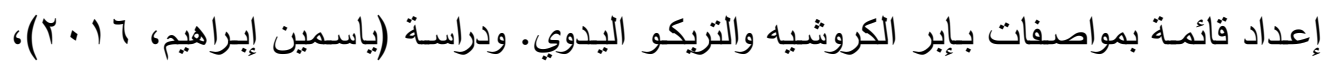

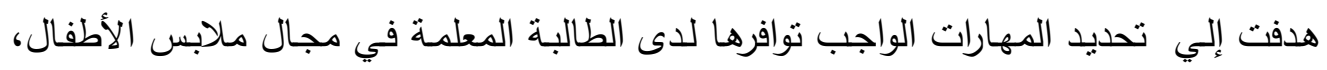

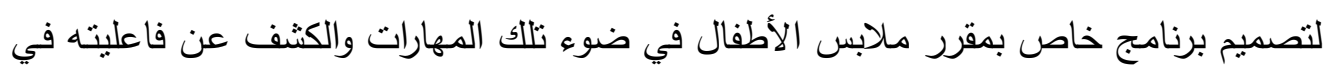
زيادة معدلات تحقق الجانب الجمالي والوظيفي لملابس الأطفال.

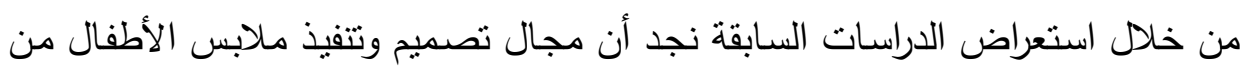

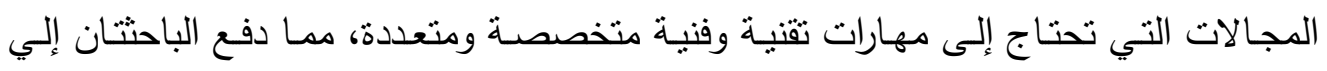

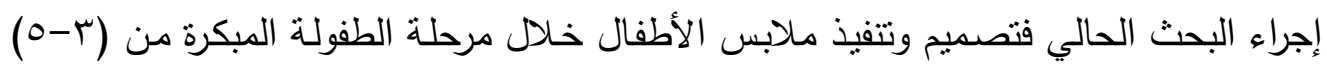

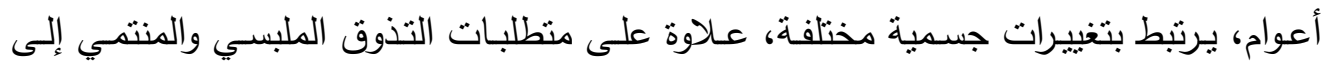

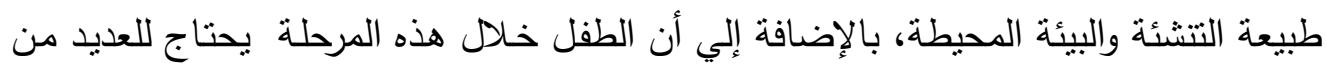

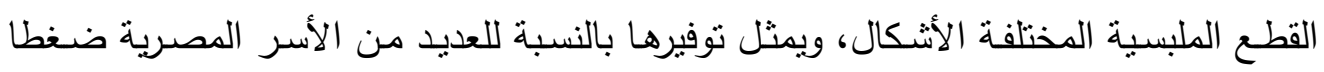

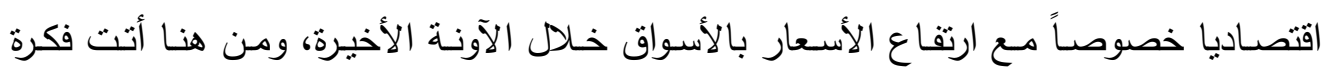

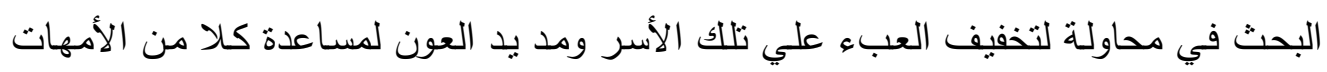

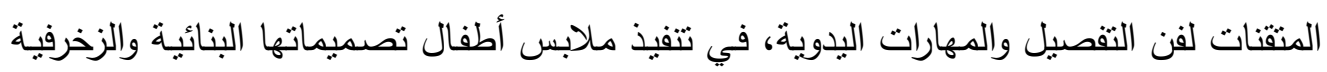
بسيطة وسهلة والارتقاء بالقيمة الجمالية لها بتطويع المهارات اليدوية المختلفة بطرق متعددة فالأساليب الفنية المستخدمة لإحداث الزخرفة على الملابس ينشأ عنها اختلاف المنتج وتعدد

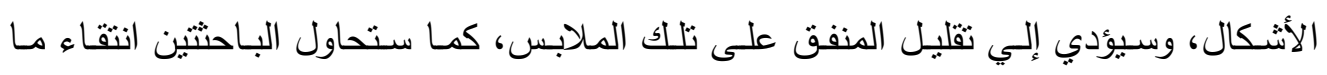

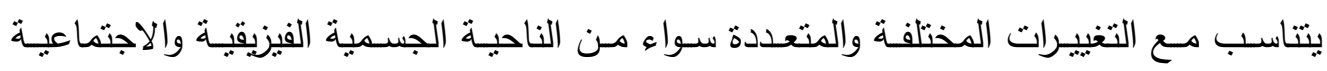
والنفسية، ومتطلباتها خـلال هذه المرحلة، لنحصل علي منتج ملبسي مميز ، وكذلك مساندة

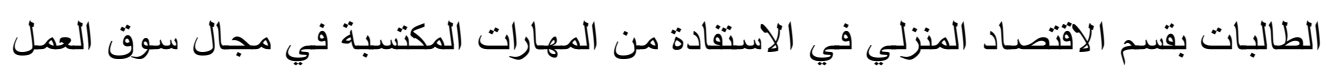

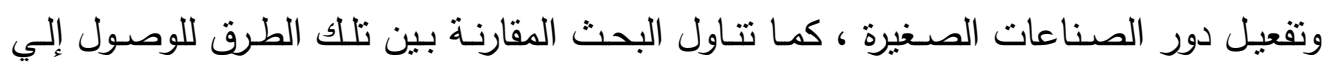

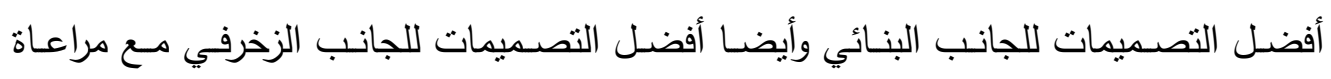
تتاسب الثكل العام الجمالي والثكل الوظيفي ومدى الملائمة للمرحلة العمرية للطفولة المبكرة، ويمكن تلخيص مشكلة البحث الحالي في التساؤلات التالية :-

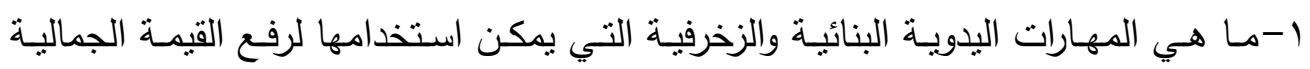
لملابس الأطفال في مرحلة الطفولة المبكرة (r-0) ؟ 
ץ-ما هو تأثير استخدام المهارات اليدوية فى التصميم البنائي والزخرفي على الجانب الوظيفي

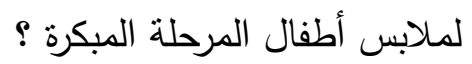
r-ما إمكانية تطويع المهارات اليدوية البنائية والزخرفية في زخرفة ملابس الأطفال في مرحلة الطفولة المبكرة (ب-0)، لرفع قيمتها الجمالية ؟ البهابه

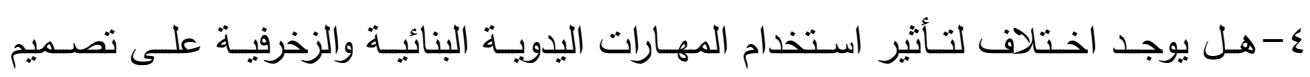

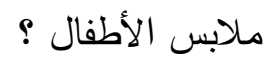

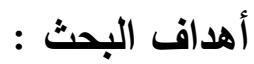
ا-التعرف على المهارات اليدوية المختلفة التي يمكن أن تُستخدم لزخرفة ملابس الأطفال في مرحلة الطفولة المبكرة (ب-O). ץ-توضيح تأثثر استخدام المهارات اليدوية المنفذة فى التصميم البنائي والزخرفي على الجانب الجمالي لملابس الأطفال.

ب-توضيح تـأثير استخدام المهارات اليدويـة فـى التصـيم البنـائي والزخرفي على الجانب الوظيفي لملابس الأطفال.

ع-الوصول بالدراسة إلى الأسلوب الأمثل لملائمة التركيب البنائي والزخرفي لملابس الأطفال باستخدام المهارات البدوية. ه-إنتاج ملابس أطفال أقل تكلفة وأكثر تميزاً وقيمة جمالية عالية.

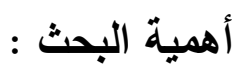

1- محاولـة الارتقاء بالجانب الجمـالي لملابس الأطفال خـال مرحلـة الطفولــة المبكرة بمـا يتتاسب مع نموه الجسمي والنفسي ومتطلباتهما خلال هذه المرحلة.

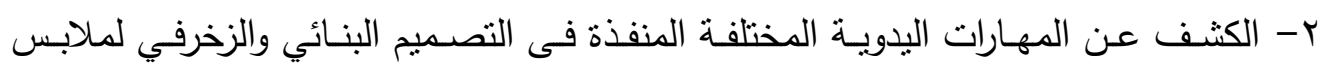
الأطفال، ومدى تأثيرها على الجانب الجمالي، والجانب الوظيفي.

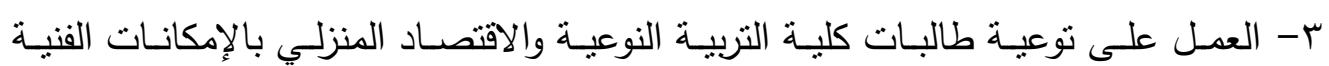
للمهارات اليدوية المختلفة التي يمكنهن توظيفها في تجميل ملابس الأطفال.

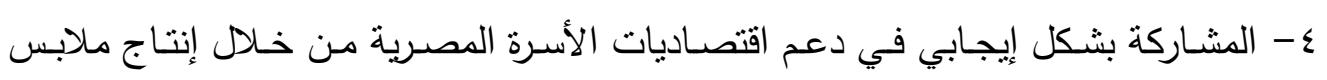
بتكاليف اقتصادية أقل، وذات عمر استهلاكي أطول، وشكل أجمل. 


$$
\text { حدود البحث : }
$$

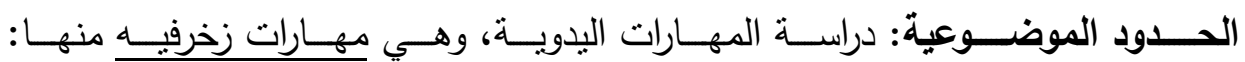

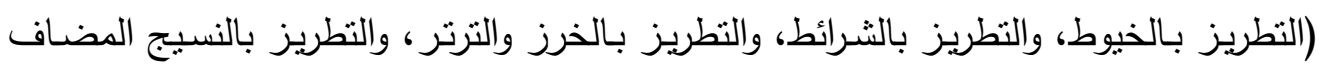

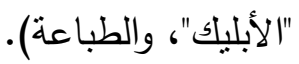
مهارات بنائيـة منها: (الكروشيه، والتريكو، والنسيج بـالخيوط، والنسيج بـالخرز ، والنسيج

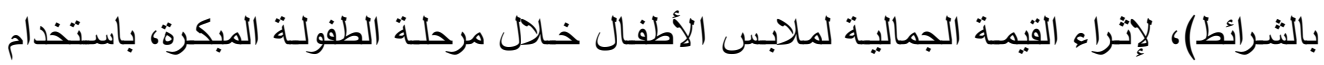
خامات، وألوان مختلفة.

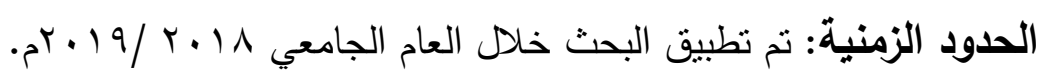
الحدود البشـرية : تم تتفيذ المنتجات من قبل طالبات الفرقة الأولى للاراسـات العليا بقسم

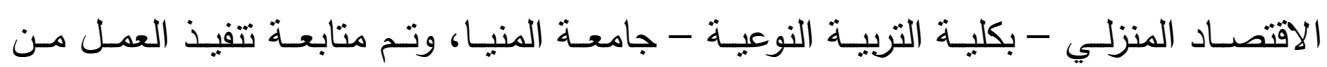

$$
\text { منبل الباحثتين. }
$$

استخدمت البحث الحالي المنهج الوصفي التجريبي.

• المنهج الوصفي : وذلك في وصف كل أسلوب من المهارات اليدوية التي تم استخدامها للتصميم البنائي أو الزخرفي لملابس أطفال المرحلة المبكرة.

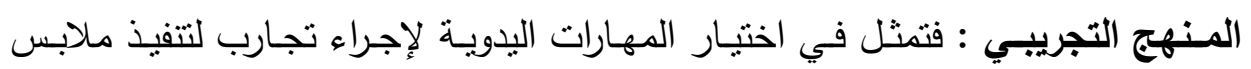

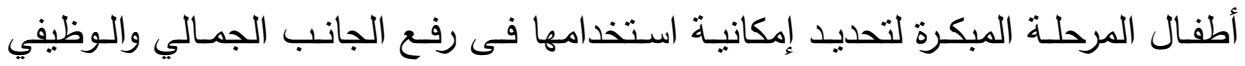
للقطع المنفذة.

$$
\text { أدوات البحث : }
$$

1- استمارة استبيان لأراء المحكمين نحو ملابس الأطفال المنفذة ومزخرفة بالمهارات اليدوية المختلفة، من إعداد الباحثتان. ץ- استمارة استبيان لأراء المستهلكات نحو ملابس الأطفال المنفذة ومزخرفة بالمهارات اليدوية المختلفة، من إعداد الباحثتان.

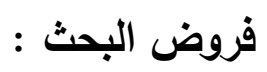
1-توجد فروق ذات دلالة إحصـائية بين المهارات الزخرفية للتصميمات الخمس في تحقيق القيم الجمالية وفقا لأراء المتخصصين. 
r-توجد فروق ذات دلالة إحصـائية بين المهارات الزخرفية للتصميمات الخمس في تحقيق القيم الوظيفية وفقا لأراء المتخصصين.

r-توجد فروق ذات دلالة إحصائية بين المهارات الزخرفية للتصميمات الخمس في ملاءمـة المنتج للمرحلة العمرية وفقا لأراء المتخصصين.

ع-توجد فروق ذات دلالة إحصـائية بين المهارات الزخرفيـة للتصميمات الخمس وفقا لأراء المستهكات. ه-توجد فروق ذات دلالة إحصائية بين المهارات البنائية للتصميمات الخمس في تحقيق القيم الجمالية وفقا لأراء المتخصصين. ج-توجد فروق ذات دلالة إحصائية بين المهارات البنائية للتصميمات الخمس في تحقيق القيم الوظيفية وفقا لأراء المتخصصين. V-توجد فروق ذات دلالـة إحصائية بين المهارات البنائية للتصميمات الخمس في ملاءمـة المنتج للمرحلة العمرية وفقا لأراء المتخصصين.

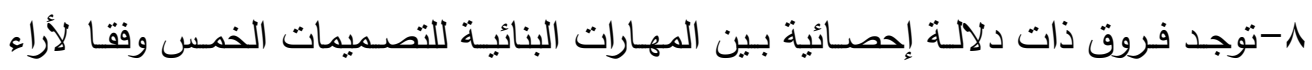
المستهكات. 9-نوجد جذوى اقتصادية من استخدام المهارات اليدوية فى تتفيذ ملابس أطفال المرحلة المبكرة. عينة البحث : تكونت عينـة البحث من (• () منتجات لملابس الأطفال خـلال مرحلة الطفولة المبكرة منفذة بالمهارات اليدوية بأساليبها المختلفة.

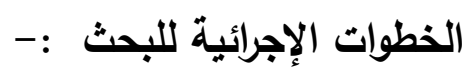
أتبع البحث الإجراءات النظرية، والتطبيقية التالية:

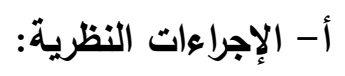

- الاطـلاع على الدراسـات والبحوث السـابقة للاراسـة الحالية الخاصـة بالطفل خـلال مرحلة الطفولة المبكرة، وطرق زخرفتها. - تحديد أساليب الزخرفة المختلفة المناسبة للطفل خلال مرحلة الطفولة المبكرة.

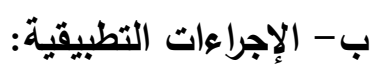
- تصنيف المهارات اليدويـة المختلفة التي يمكن تطويعها بشكل بنـائي أو زخرفي داخل تصميم ملابس الطفل. 
- إعداد تصميمات تتاسب المهارات اليدوية المقترحة لملابس الأطفال، والمرحلة العمرية.

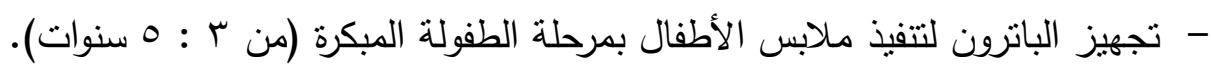

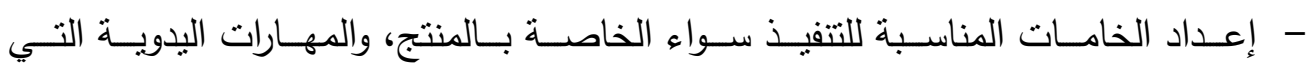
سنطبق عليه. - تتفيذ التصميمات بالتقنيات والخطوات العلمية المدروسة.

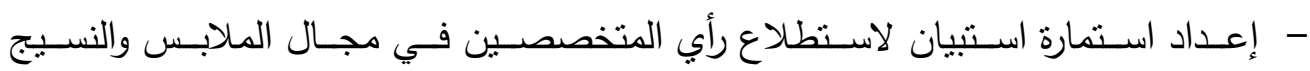
للتصميمات المقترحة ملحق رقم (1). - - إعداد استمارة استبيان لاستطلاع رأي المستهلكات للتصميمات المقترحة ملحق رقم (Y). - تطبيق الاستبيان على المحكمين ملحق رقم (r). - تطبيق الاستبيان على المستهلكات.

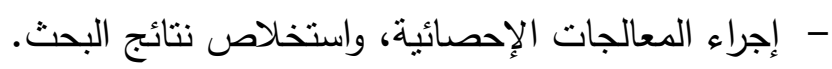
- تقديم التوصيات، والمقترحات الخاصة بالبحث.

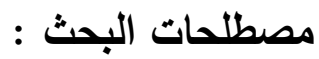
التعريف الاجرائي لملابس أطفال المرحلة المبكرة : هي الأقشـة التي يتم حياكتها أو يتم تشكيلها بطرق مختلفة وتتشمل التتورات والقمصنان

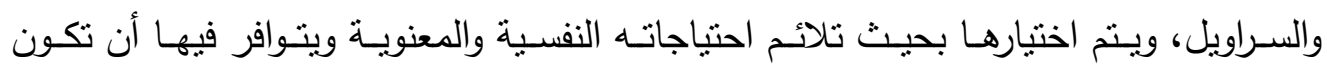
فضفاضة ومريحة. مرحلة الطقولة المبكرة

تعرف مرحلة الطفولة المبكرة تربوياً بمرحلـة ما قبل المدرسـة (رياض الأطفال)، وتحتل

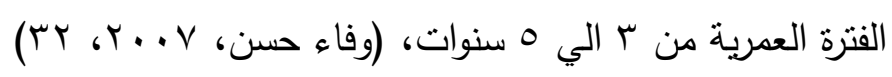
:صesign

ذكر (إسماعيل شوقي، 991 (1)، أن التصميم هو : "العملية الكاملة لتخطيط شكل شيء

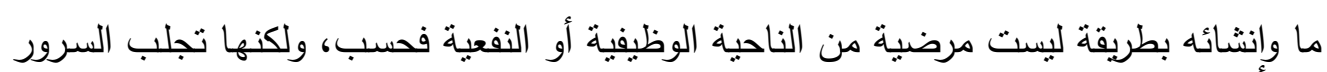
والفرحة إلي النفس أيضا، ويعتبر هذا إثباع لحاجة الإنسان نفعيا وجماليا في وقت واحد". الإمكانات الجمالية (The Aesthetic Potential) ذكرت "نفيسة عبد الرحمن" أنها " مـا بحتويه العمل الفني من سمات وعناصر جمالية تميزه عن غيره نتيجة لاستخدام الوسائل والطرق الفنية التي تبرز الناحية الجمالية"، (نفيسة عبد

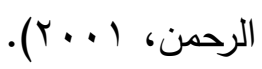




\section{التعريف الإجرائي الإمكانات الجمالية:}

صفات شكلية مرئية تضيفها المهارات اليدوية علي الملابس وتجعلها مميزة ومرغوب في تأملها وارتدائها ومستحقة للتقدير لدي الطفل ولدي المحيطين بـه، فيقبل علي ارتدائها لتوفر العلاقات الحسية بها وشعوره بالبهجة والجمال.

التعبريف الإحرائي للمهرات البيدوية البنائبة:

مهارات تسـتخدم لرفع القيمـة الجماليـة للقطعـة الملبسية بأسـاليب تزبين تدخل في بنـاء القطعة نفسها وتعتبر جزء منها لا يمكن إزالتها ولا تكتمل القطعة الملبسية بدونها، مثل شـل جزء الصدر أو الكم بالكروشيه، أو التريكو.

\section{التعريف الإجرائي للمهارات اليدوية الزخرفية:}

مهارات تستخدم لرفع القيمة الجمالية للقطعة الملبسية بأساليب تزبين مضافة علي بنائها دون دخولها في بناء القطعة نفسـها، مثنل الطباعـة، والتطربز الآلي واليدوي بفنونـه المتعددة، والأقمشة المضافة بأنواعها.

\section{: Skill المههارة}

يذكر "فؤاد أبو حطب ، أمال صادق" ( . . . . ص: 9 (0) على أن للمهارة عدة معان منها أنها نشاط معقد يتطلب فترة من التدريب والممارسة المنظمة والخبرة المضبوطة، وعادة ما يكون لهذا النشاط وظيفة مفيدة ، ويتوقف اكتساب المهارة على عدة عوامل أهمها (درجة نضـج المـتعلم ، وتكوينـه وبنـاؤه الجسـمي، دافعيـة التعلم ، وتتظيم وحدات العمـل، وكذلك التدربب المستمر حتى الإشراف والتوجيه).

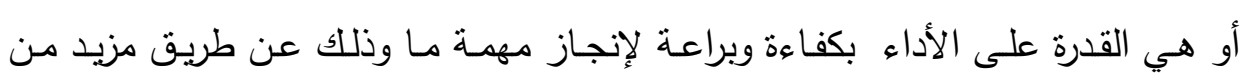
التعلم والتدريب. (Jornal 2008 ) الإطار النظري : الإن :

\section{ملابس الأطفال خلال مرحلة الطقولة المبكرة:}

تُعتبرَر مرحلة الطفولة المبكرة مرحلة هامـة من مراحل الطفولة نظرا لأنها تشهد تغيرات

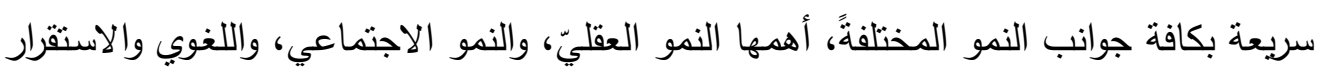
العـاطفيّ والنفسي، ومسن الجدير بالذكر أنّ شخصيّة الطفل خـلال هذه المرحلـة تصبح قويّة وناميسة ومُتفتِّـة، وينمو وعي الطفل بالجمال كما أثـارت دراسـة (غادة عبد الفتاح، وصـافيناز

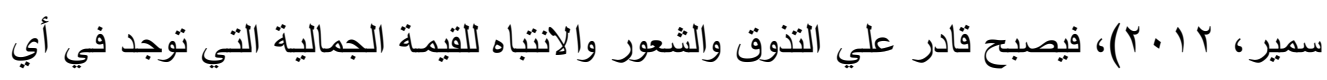


شـيء حوله، ويتمكن الطفل من أن يُميز بين الألوان ويسميها، وبصفة عامـة يفضل الطفل

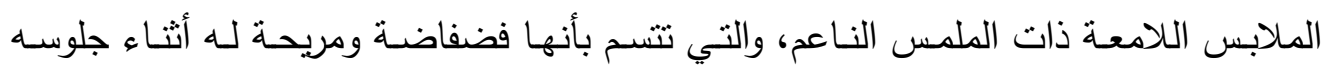
ونومهه ولعبه، فمن الضروري الارتقاء بالقيمة الجمالية لملابس الأطفال لسد احتياجات الطفل النفسية والمعنوية.

المهارات البدوية

المهارة هي القدرة علي الأداء المتقن لمجموع الممارسات الفنية التي نحتاج إليها لتنفيذ أساليب الزخرفة المختلفة، وتعتبر الجوانب المهارية مكملة للجوانب المعرفية، فلا يمكن الفصل الداءل بين معرفنتا لغرزة ما وخطوات عملها وبين طريقة تتفيذها المتقن، والمهارة تتأثر بالتدريب،

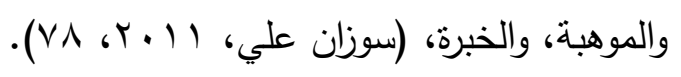

وقد تم استخدام عدد من المهارات اليدوية خلال الجانب التطبيقي للبحث، وهي: البهات

\section{أولا: المهارات اليدوية الزخرفية:}

وهي المهارات التي نستخدمها لرفع القيمة الجمالية للقطعة الملبسية للطفل بأساليب تزيين

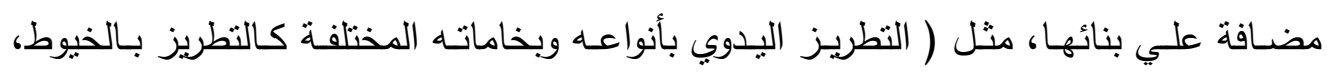

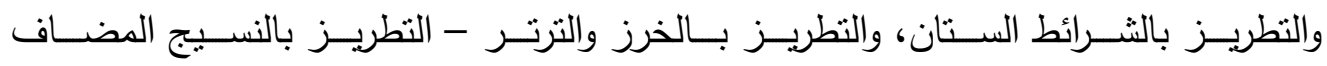

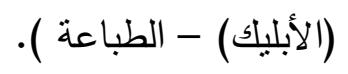

(التطريز(Embroidery):

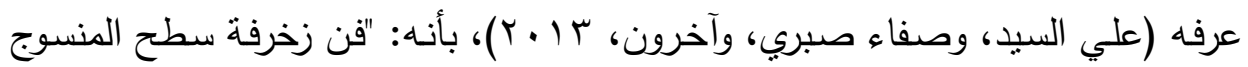

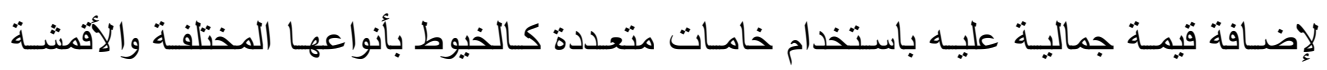
بأنواعها ورسومها المختلفة والخرز والترتر ". ويعتبر التطريز عنصر له أهميته في زخرفة الأقشة سواء يدوياً أو آلياً لإضافة تأثثرات وملامس مختلفة لسطح النسيج، بطرق متتوعة ومتعددة.

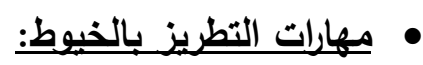

يشتمل على العديد من أثنكال الغرز المختلفة والتي تُقفذ يدوياً أو آلياً، وهو أثنهر أنواع

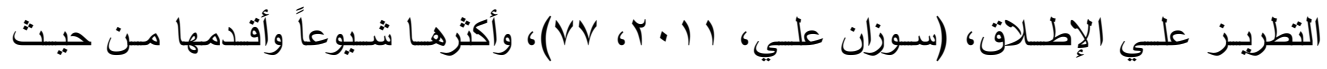

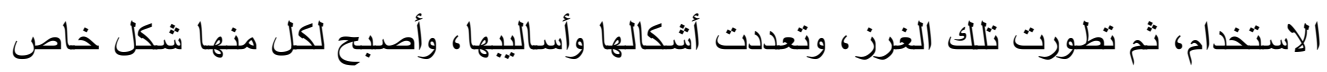

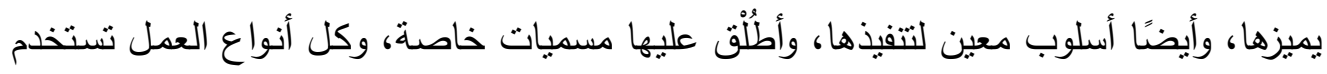
بهدف إضافة قيمة جمالية وإثراء القطع المطرزة. 


\section{مهارات التطريز بالثرائط:}

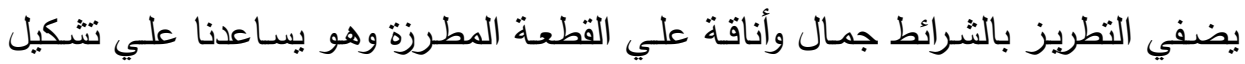

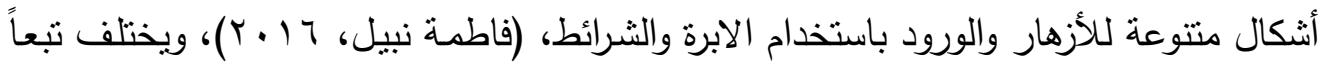

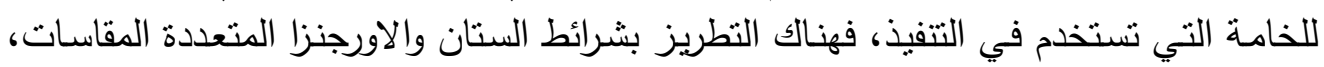
وهي شرائط تصنع من خامة نسيجية صناعية يطلق عليها (الريون).

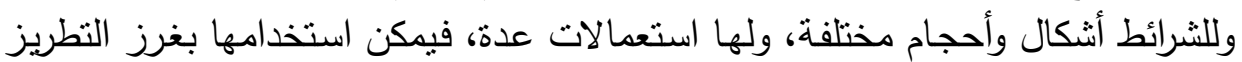

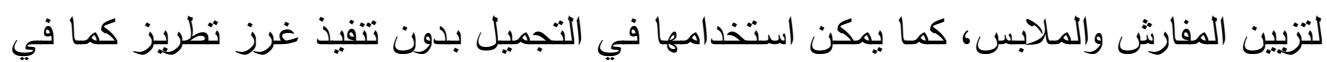

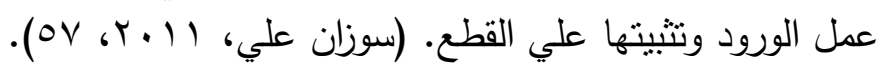

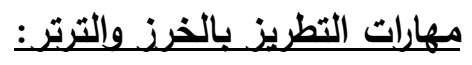

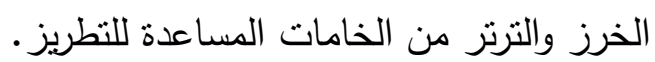

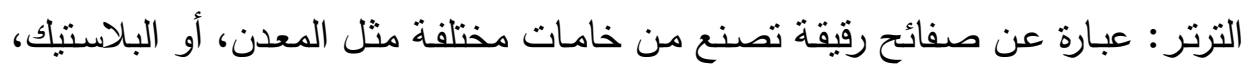

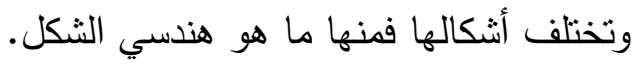
وتختلف ألوان الترتر فقد يكون ذا ألوان براقة، أو ملونة بألوان مطفأة، وتثبت من خـاد

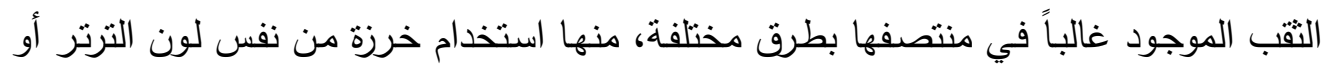

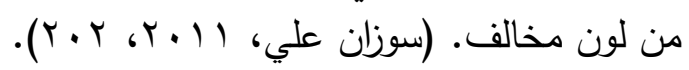

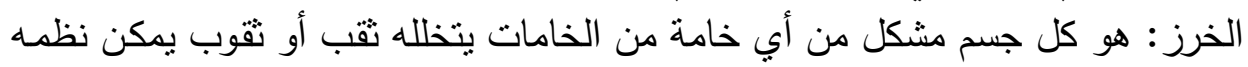

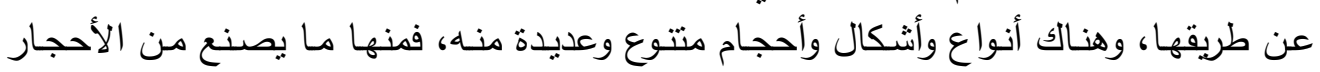

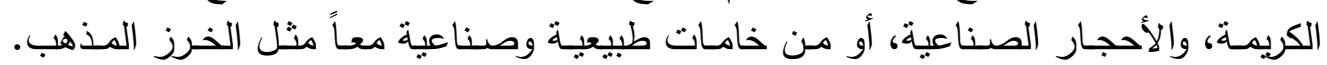

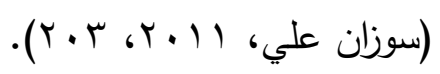

\section{مهارات التطريز بالنسبج المضاف "الأبليك":}

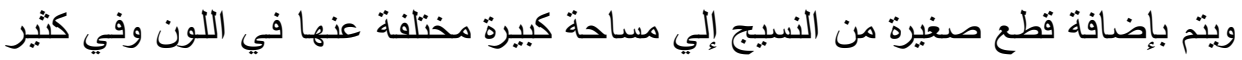

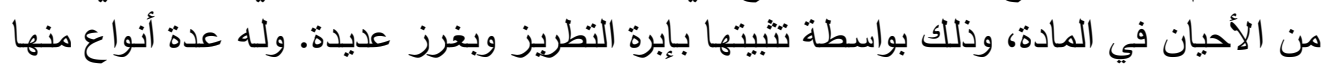

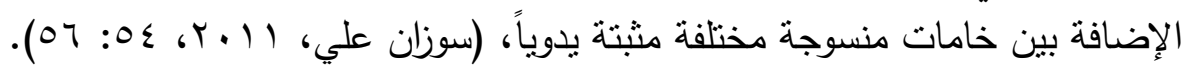
الطباعة (printing)

هي صباغة موضوعية يتم نقل الرسم أو التصميم الي سطح الخامة بحيث تُشكل أثنكالاً،

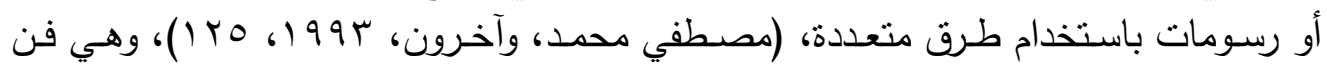

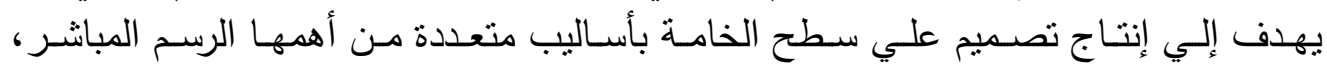

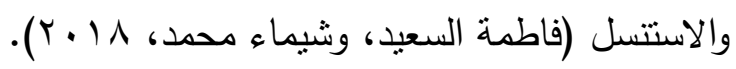

\section{الطباعة بالاستنسل:}

هو أسلوب لنطبيق الأصباغ أو الألوان علي القماش عن طريق اليد أو آلة الطباعة، من

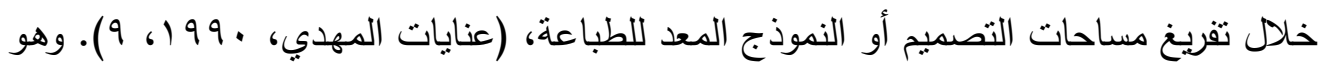
من أقد الطرق اليدوية المستخدمة في طباعة المنسوجات. 
ثانياً: المهارات البيوية البنائية:

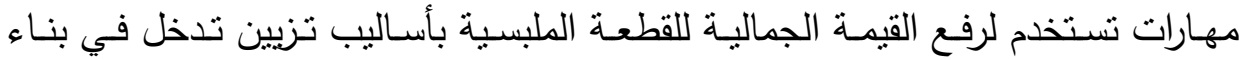

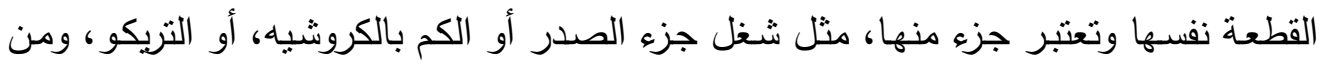

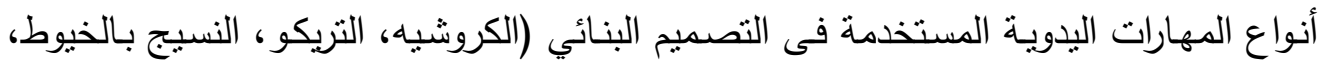

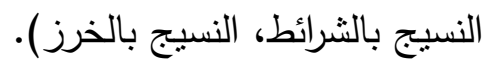

الكروشيه (Crochet):

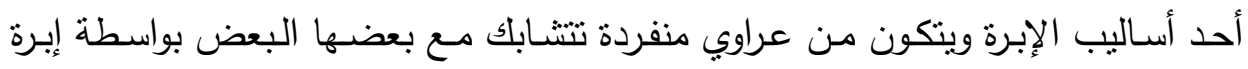

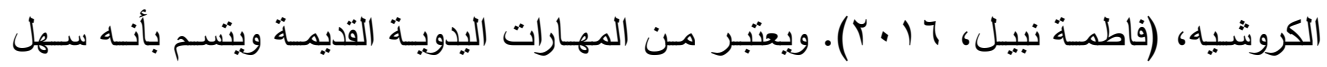

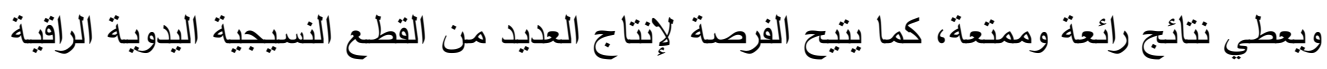

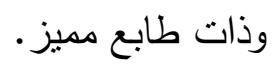

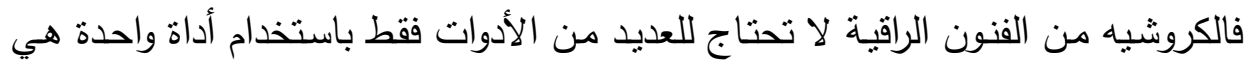

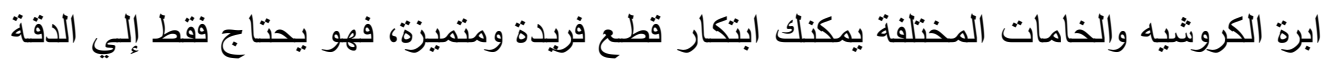
في أداء التنفيذ.

التريكو (Knitting)

وهو طريقة لشبك الخيوط وتحويلها إلى قماش محيك يتألف من عدد من صفوف الحلقات

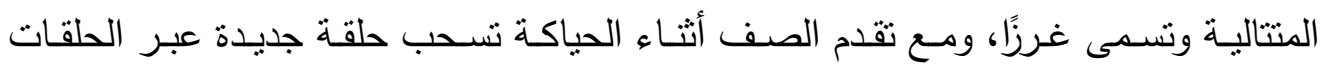
القديمة. ويتم حجز الغرز النشطة بواسطة الإبر الخاصة بهذا بهذا الفن حتى تنمكن الغرزة التالية

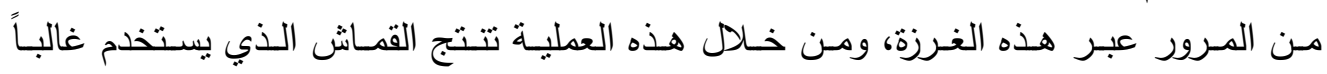

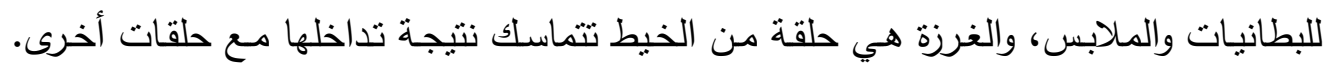
وهذه البنية الخاصة لأقمشة التريكو تكسبها مرونة عالية. (www.wikipedia.com)

النستج (Textile)

وفن النسيج من الفنون التي تشمل العديد من التقنيات والتراكيب النسيجية، ولكل تركيب إنباء

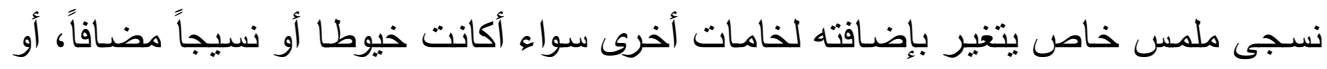

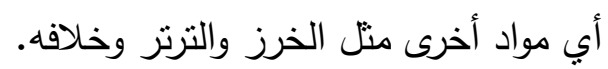

\section{مهارات نسبج بالخيوط:}

وتعددت طرق وأساليب استخدام النسيج بالخيوط ولعل أجملها من ناحية التعبيرات الفنية

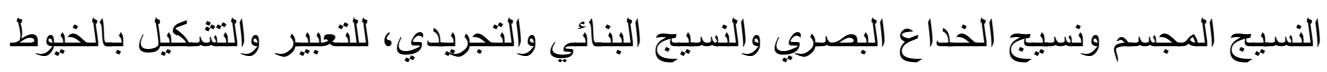

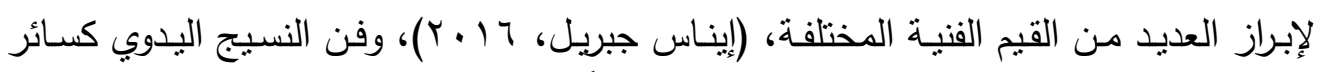

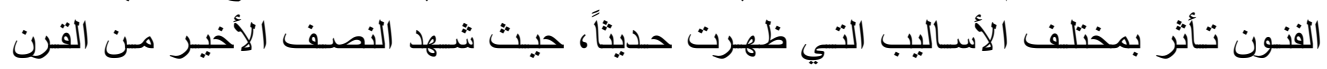

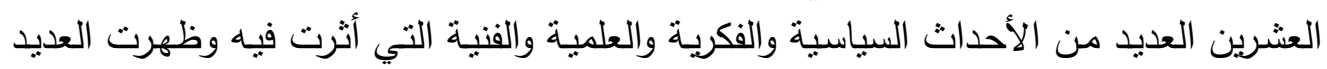
من الاتجاهات والحركات الفنية التي ساهمت في تغيير مفهوم فن النسيج. 


\section{مهارات نسبيج الثرائط:}

هو نوع من أنواع النسيج اليدوي ويمكن أن ينت بدون استخدام الانوال، وباستبدال الخيوط

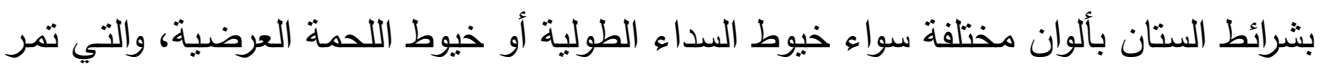
تحت وفوق خيوط السداء علي التوالي مما يؤدي إلي تعاثقهما معاً، ويضفي أنشكالاً جمالية تشيع بالبهجة.

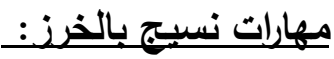

ينفذ نسيج الخرز عادة بالنول تبعا لتصميم وعليه فان عدد الخيوط المستخدمة في النول

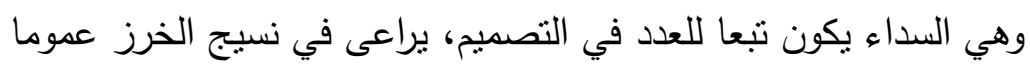

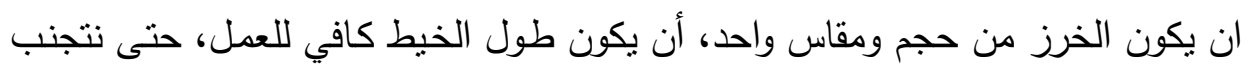

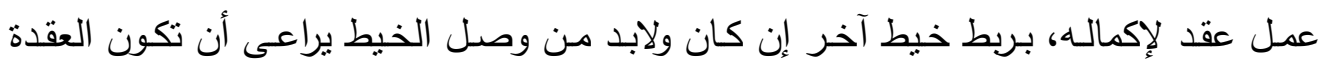

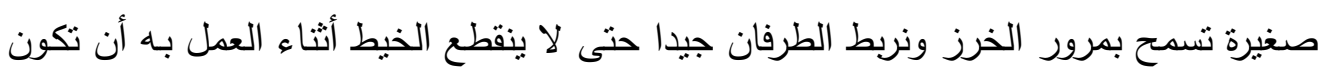

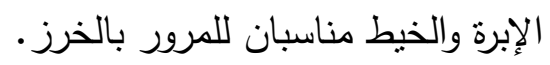

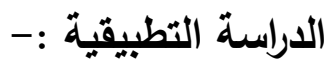

أولا : إعداد باترون لفستان طقلة سن ع عنهاته : سنوات.

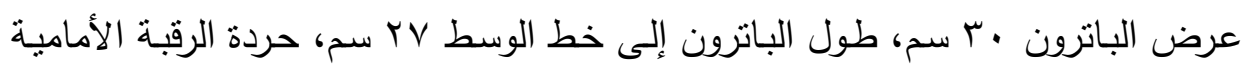

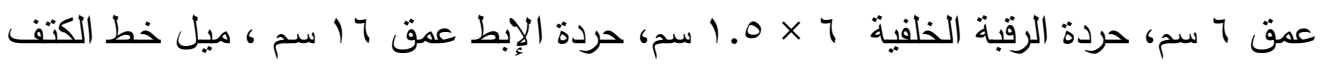

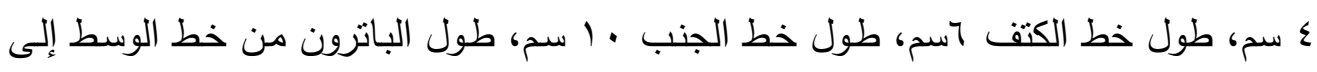

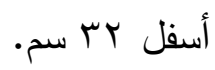
ثانيا : القطع المنفذة باستخدام المهارات اليدوية للتصميم الزخرفي 1-التطريز بالخيط :

\begin{tabular}{|c|c|}
\hline خطوات التنفيذ : & وصف الموديل : \\
\hline 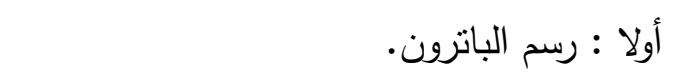 & اللــون : فسـتان مـن اللـون الأسـود × \\
\hline ل امات المستخدمة :-- & \\
\hline • نص منر حرير ايزيس من اللون الأسود، & وصف التصـيم : فستان بدون أكهـام \\
\hline ا متـر تـل متوســط الســك & وبفتحة رقبة مستديرة. \\
\hline البمبي، منز قماش ستان متوسط السمك & الجزيء العلـوي : عبارة عن قطعـة من \\
\hline مـن نفس لـون التـل، سوسـتة مـن اللـون & قماش الحرير ايزيس من اللون الأسود. \\
\hline الأسـود، ا متر بييـهـ ستان بمبـي، خبط & الجزء السفلي : عبارة عن قماش من \\
\hline
\end{tabular}




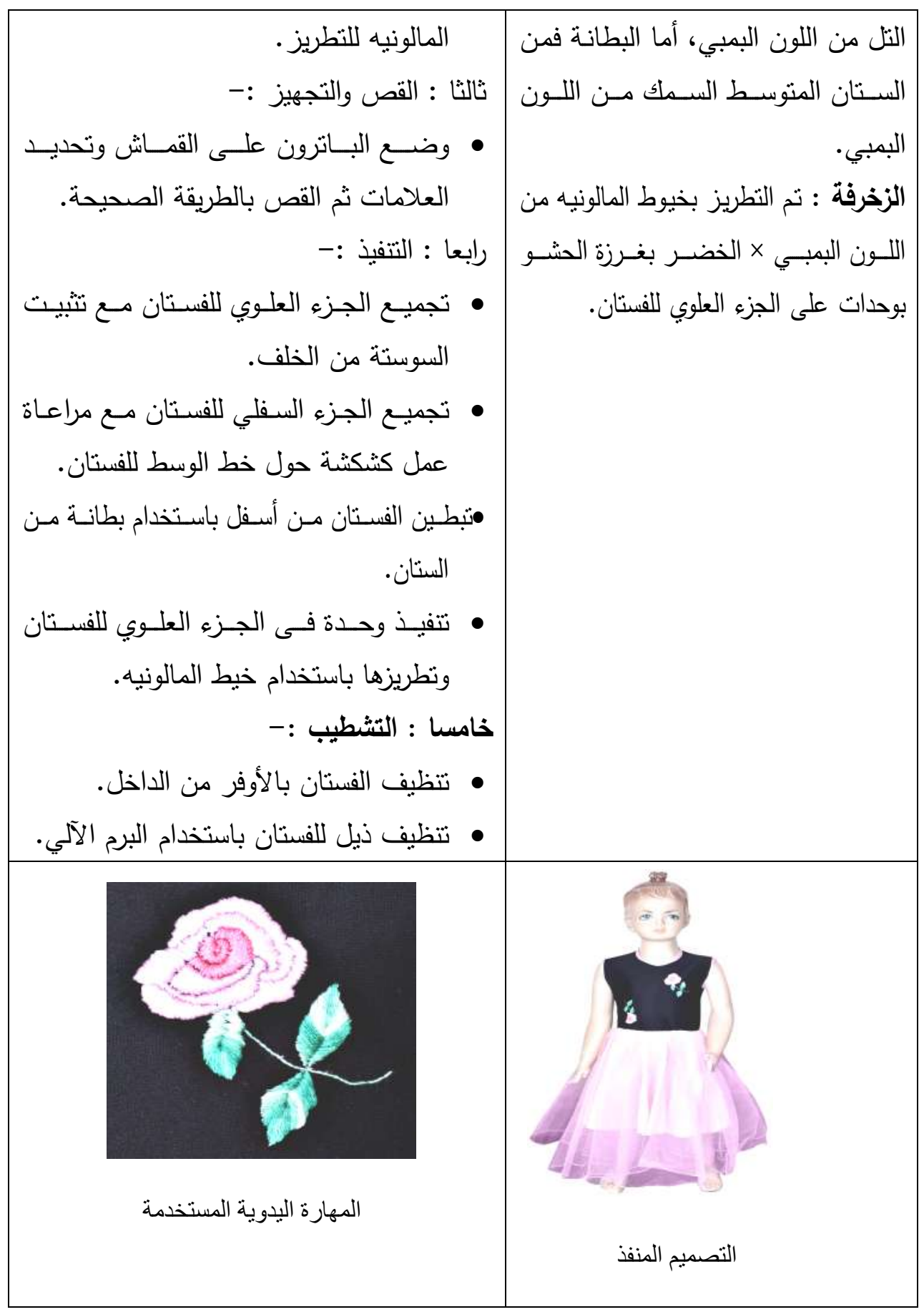


r - التطريز بالشرائط :

$$
\begin{aligned}
& \text { خطوات التنفيذ : } \\
& \text { اللون : فستان من اللون الأزرق × البمبي أولا : رسم الباترون. }
\end{aligned}
$$

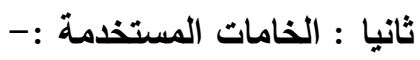

$$
\begin{aligned}
& \text { المنقوش. }
\end{aligned}
$$

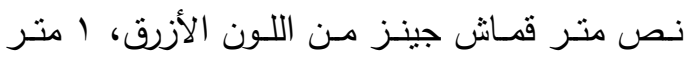
وصف التصميم: فستان بدون أكمام وحردة

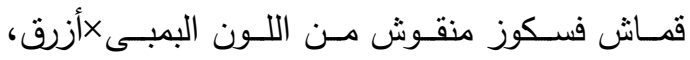

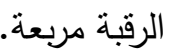

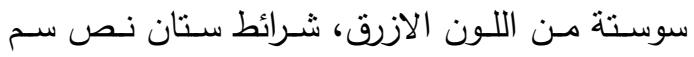
• للنطريز ثالثا : القص والتجهيز :الجزء العلوي : يحيط بجانبي الفستان مارا

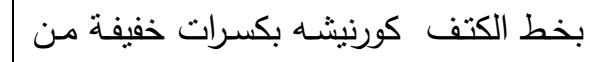

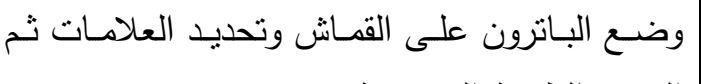

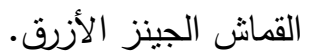
القص بالطريقة الصحيحة. رابعا : التنفيذ :- بالطربة

•تجميع الجزء العلوي للفستان مـع تثتيت السوستة من الخلف.

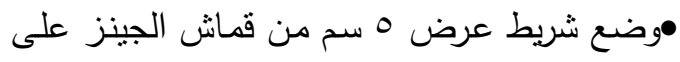

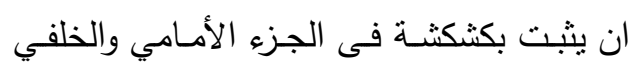

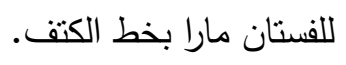
•تجميـع الجزءء السـفلي للفستـان مـع مراعـاة عملـل كثكثة حول خط الوسط للفستان. •تفيذ وحدة فى الجزء العلوي للفستان وتطريزهـا باستخدام شرائط الستان. خامسا : التشطيب :•تنظيف الفستان بالأوفر من الداخل. متظيف ذيل للفستان باستخدام البرم الآلي.

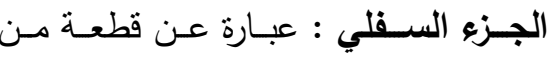

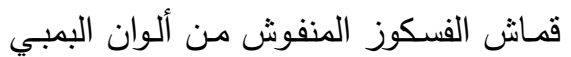

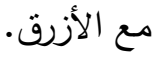
الزخرفة : باستخدام شرائط الساتان الرفيع. 


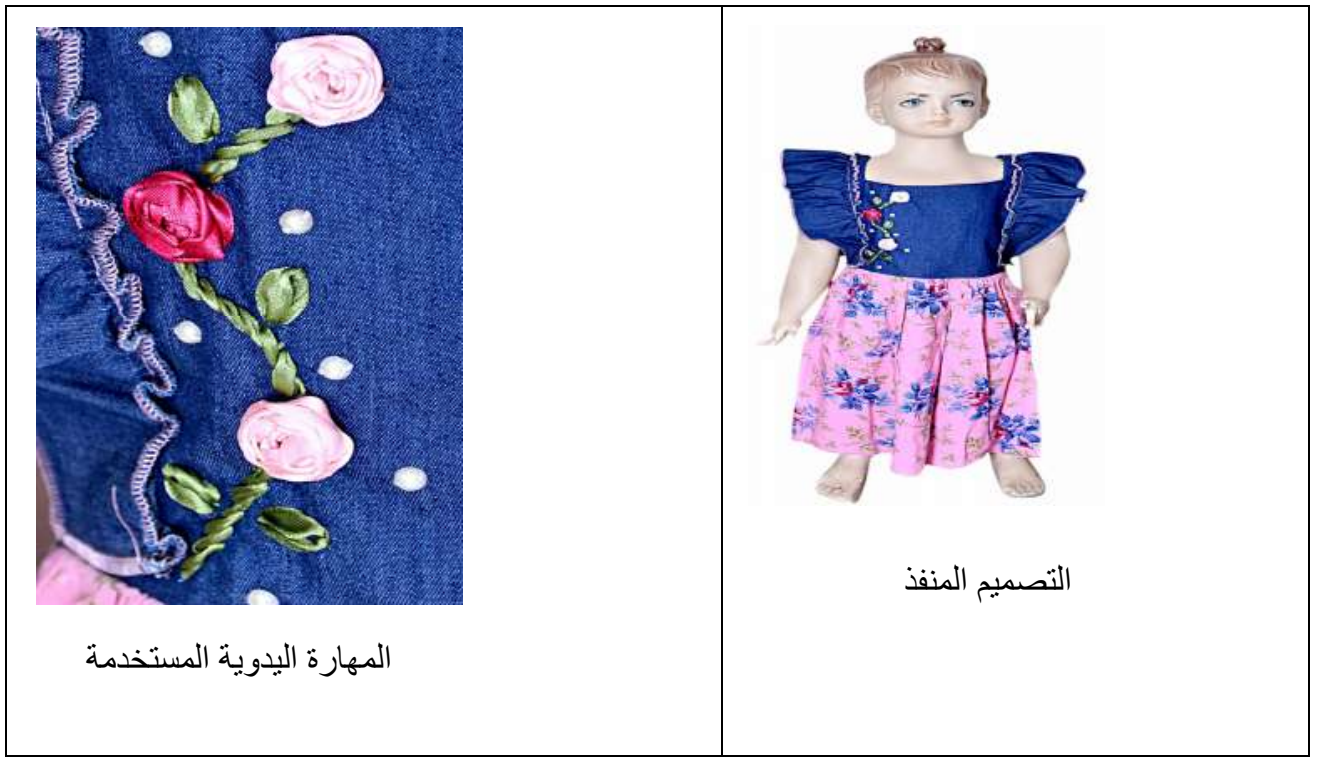

r- التطريز بالخرز وإلترتر :

\begin{tabular}{|c|c|}
\hline 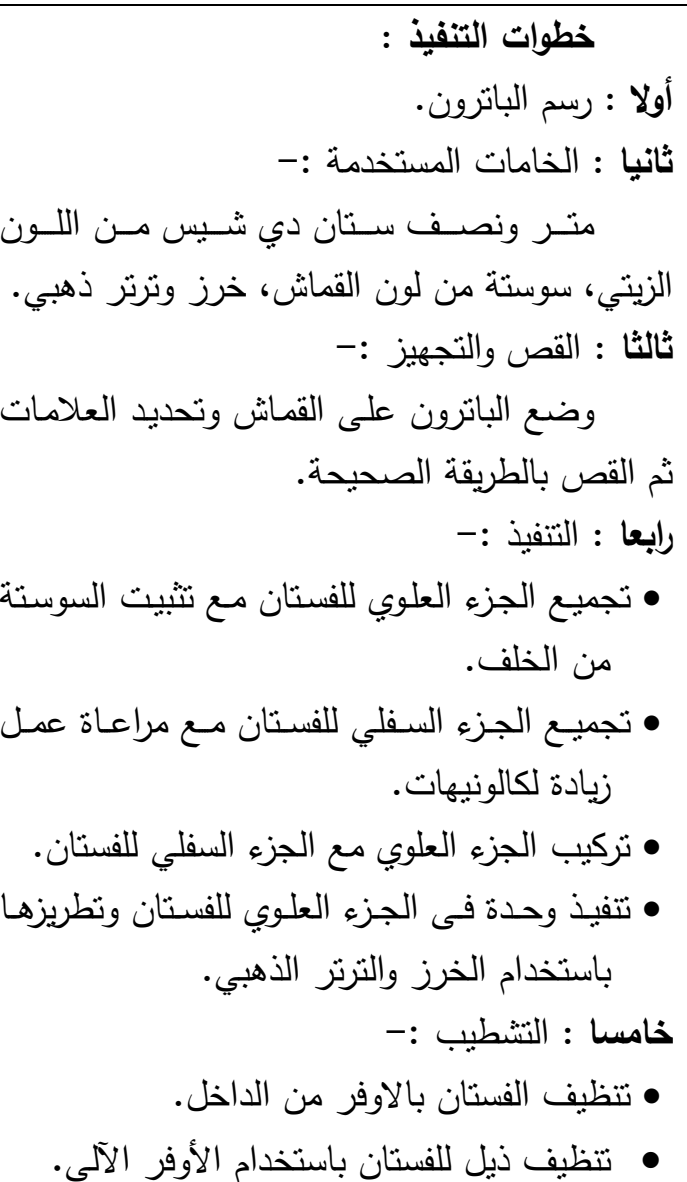 & 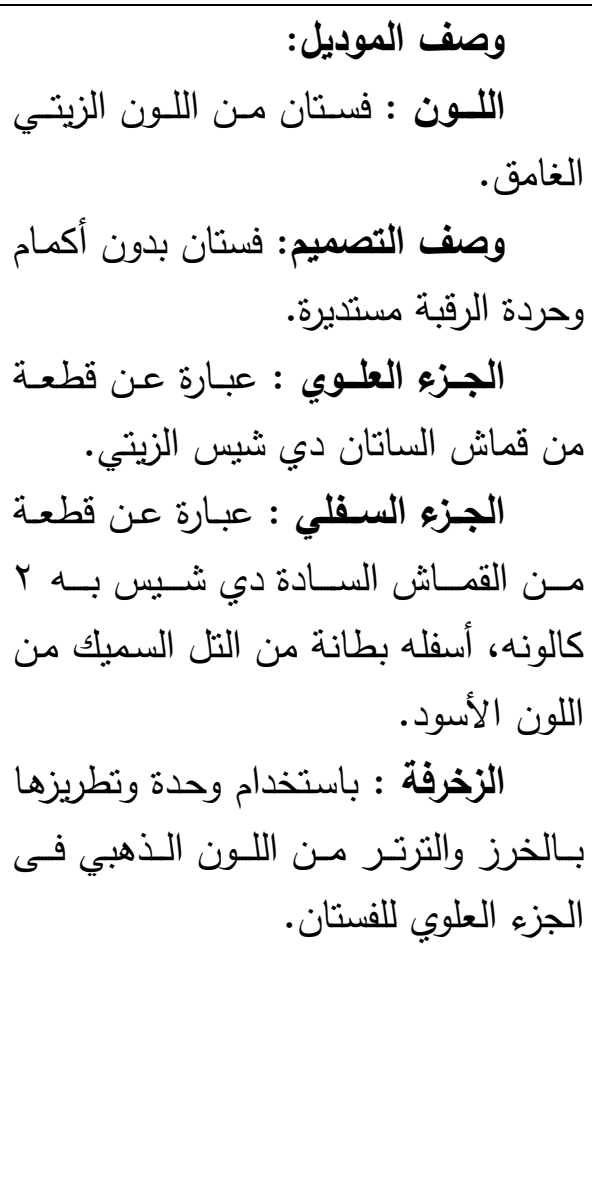 \\
\hline
\end{tabular}




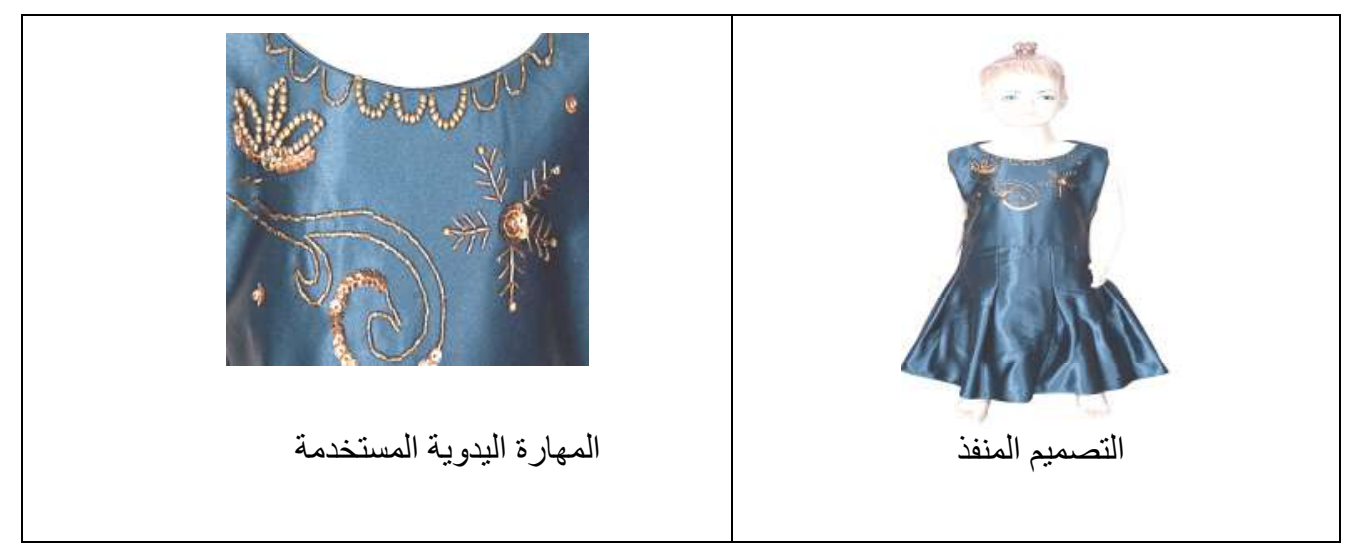

צ - التطريز بالنسيج المضاف (الأبليك) :

\begin{tabular}{|c|c|}
\hline 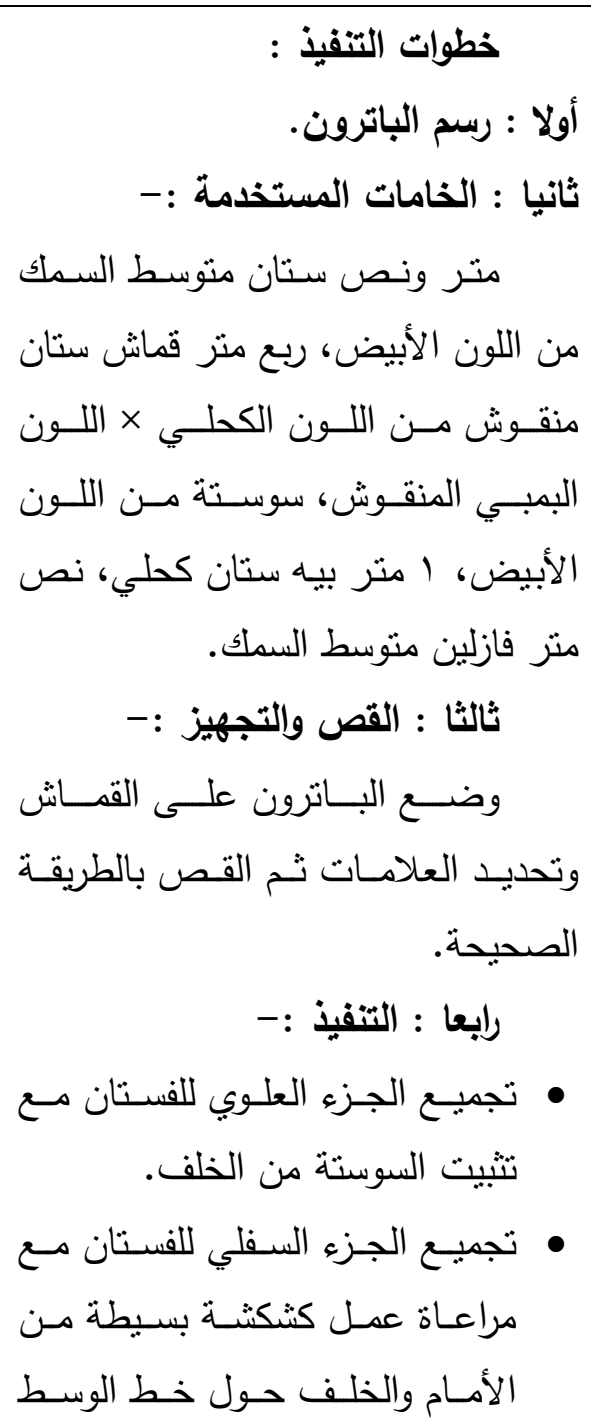 & 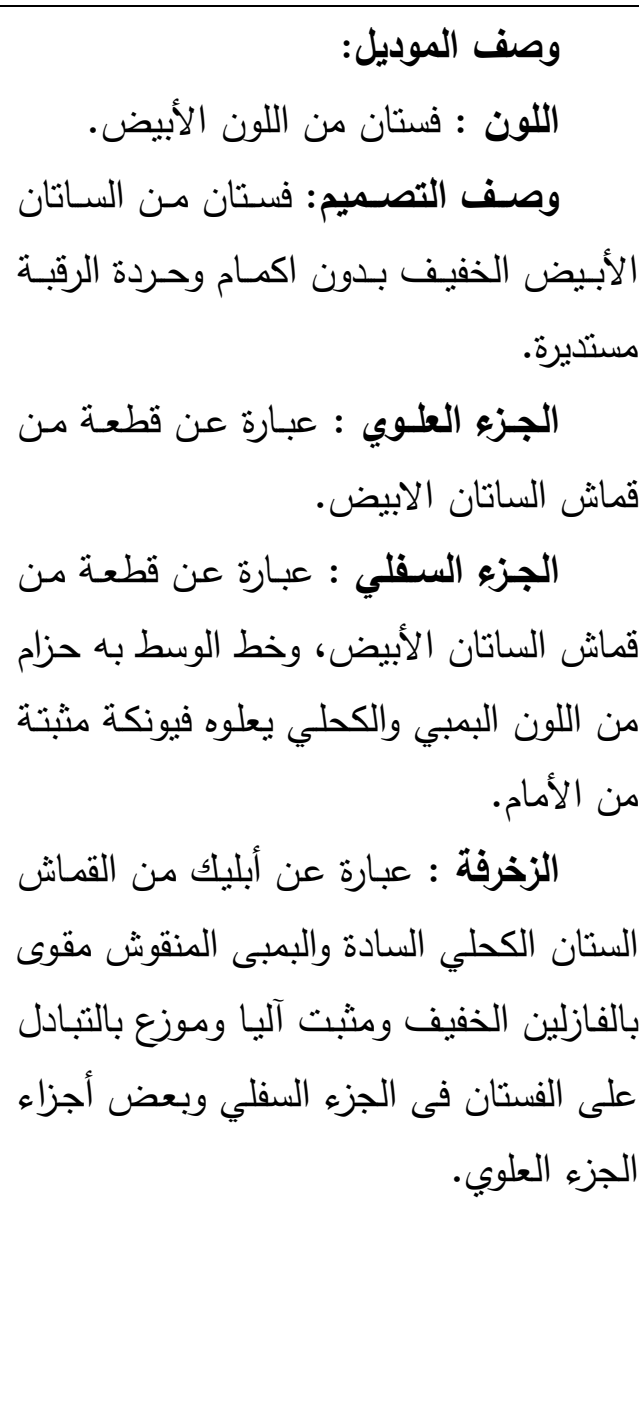 \\
\hline
\end{tabular}


العدد الثامن عشر ابريل 9 ـ ب جr

المجلة العلمية لكلية التربية النوعية

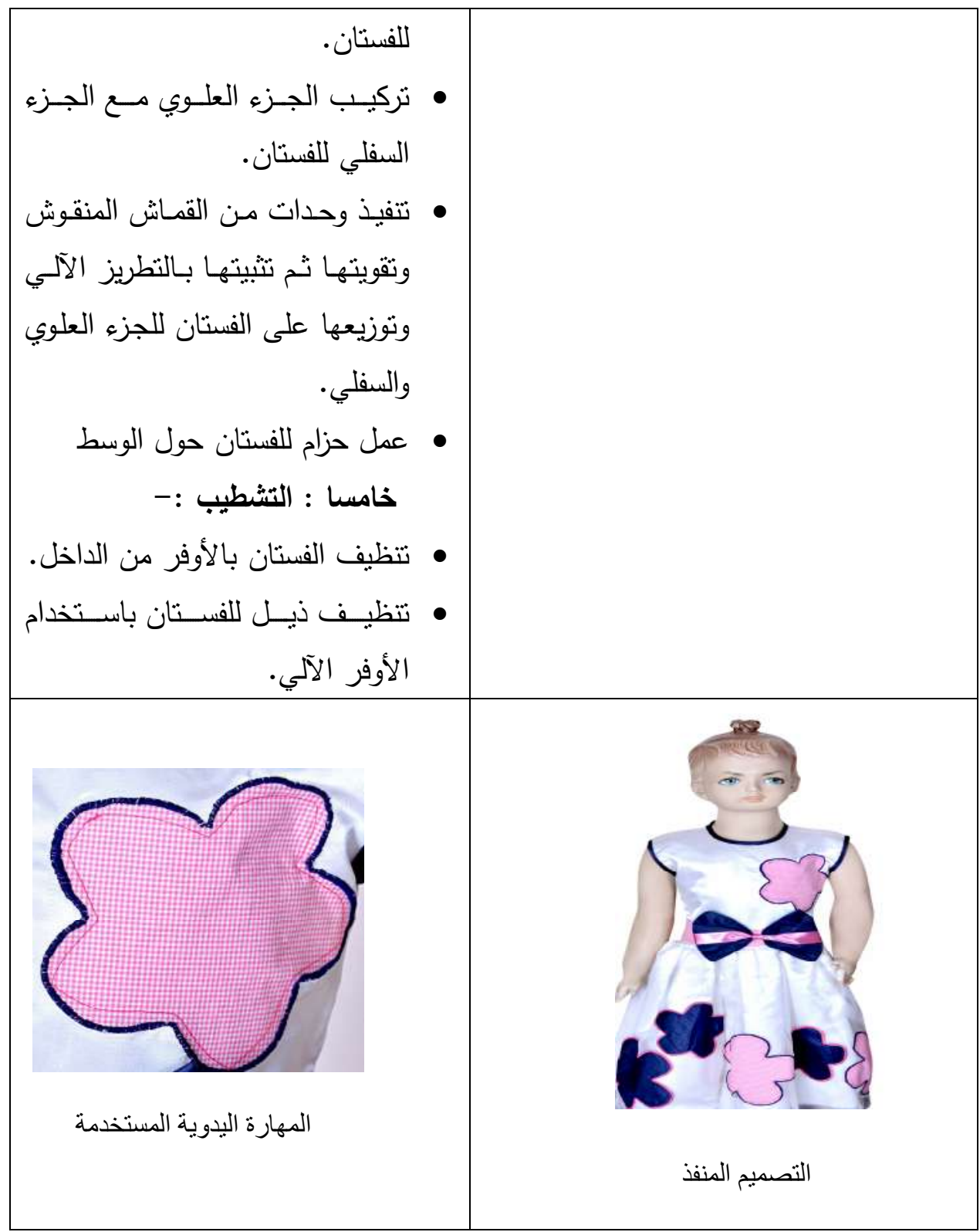


ه - الطباعة بالاستنسل :

\begin{tabular}{|c|c|}
\hline 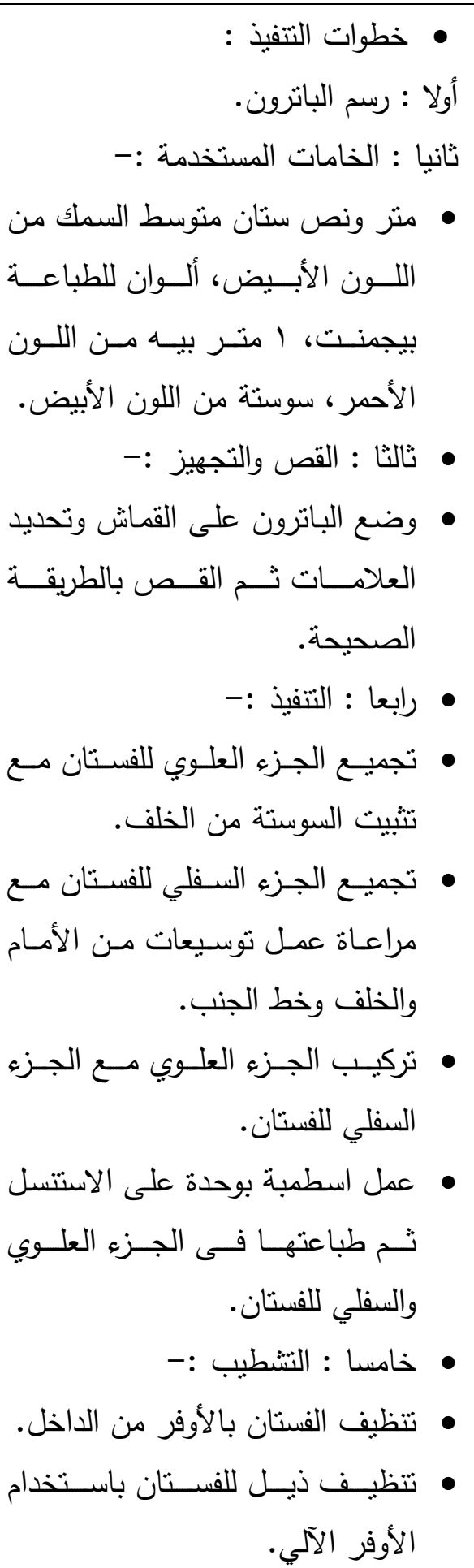 & 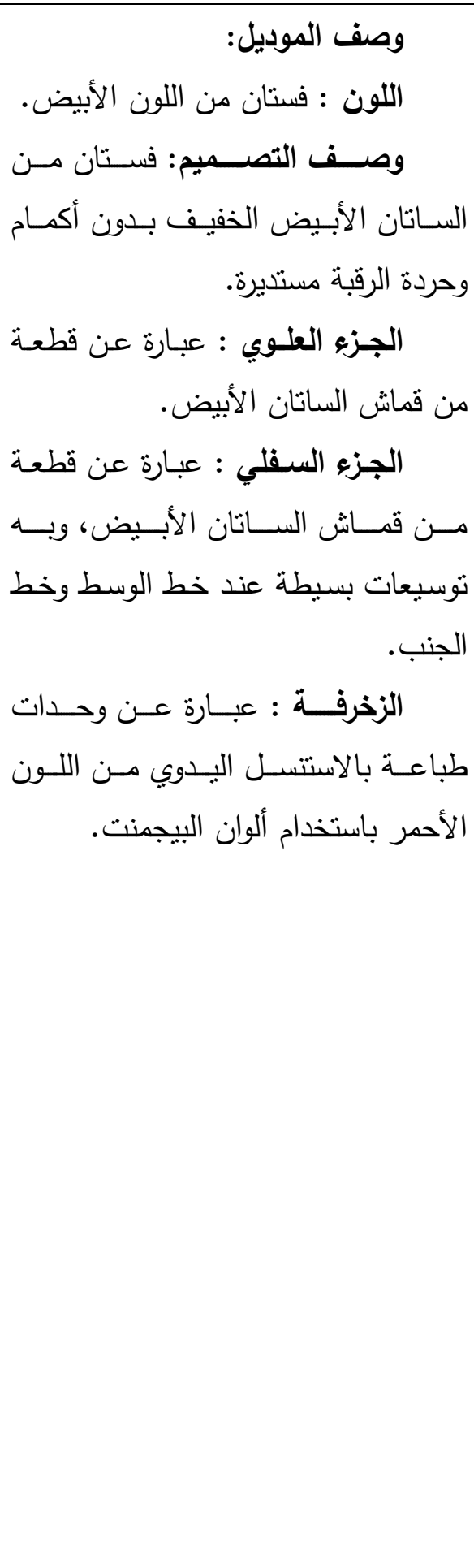 \\
\hline
\end{tabular}




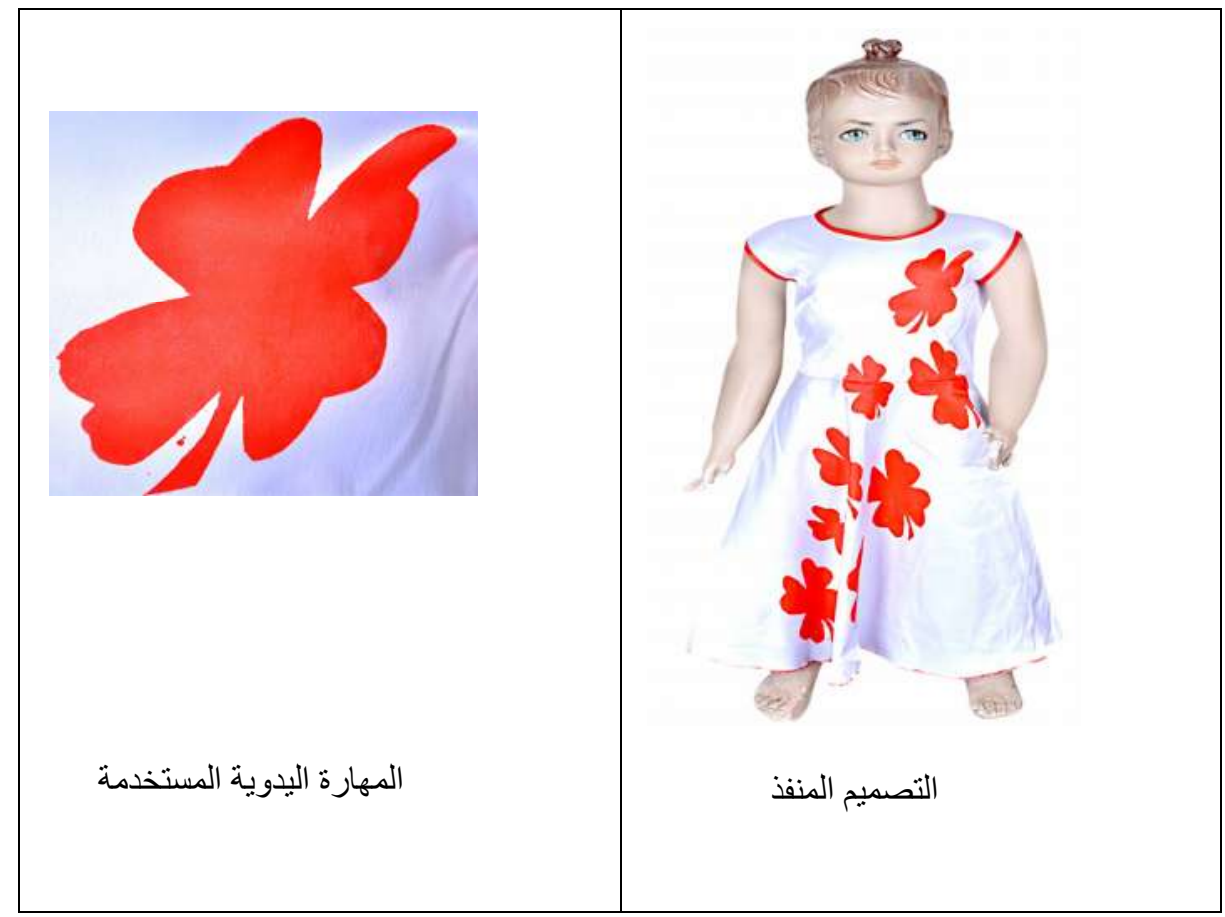

ثالثا : القطع المنفذة باستخدام المهارات اليدوية للتصميم البنائي

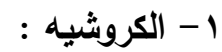

\begin{tabular}{|c|c|}
\hline 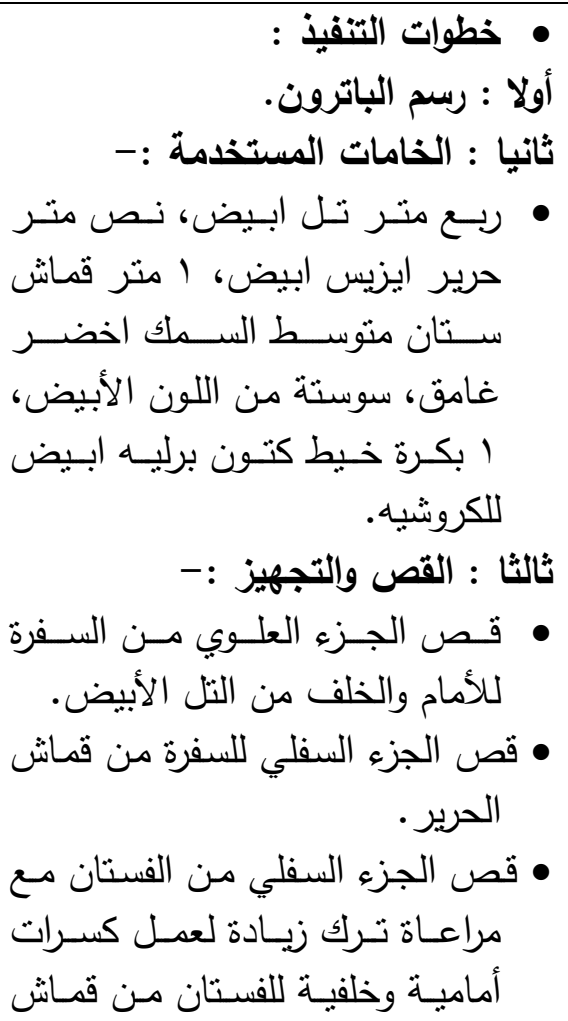 & 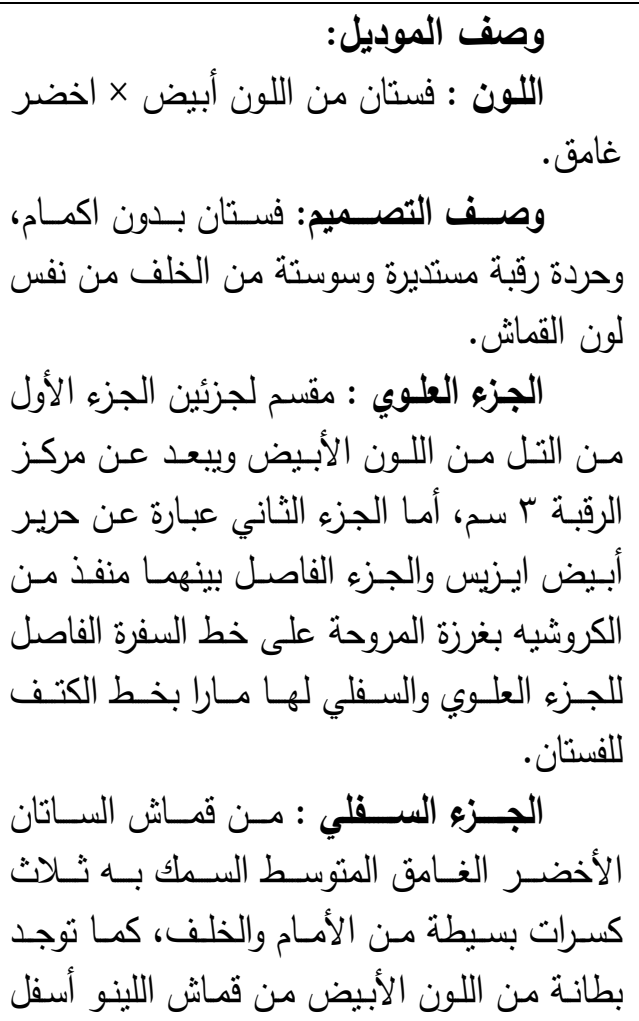 \\
\hline
\end{tabular}




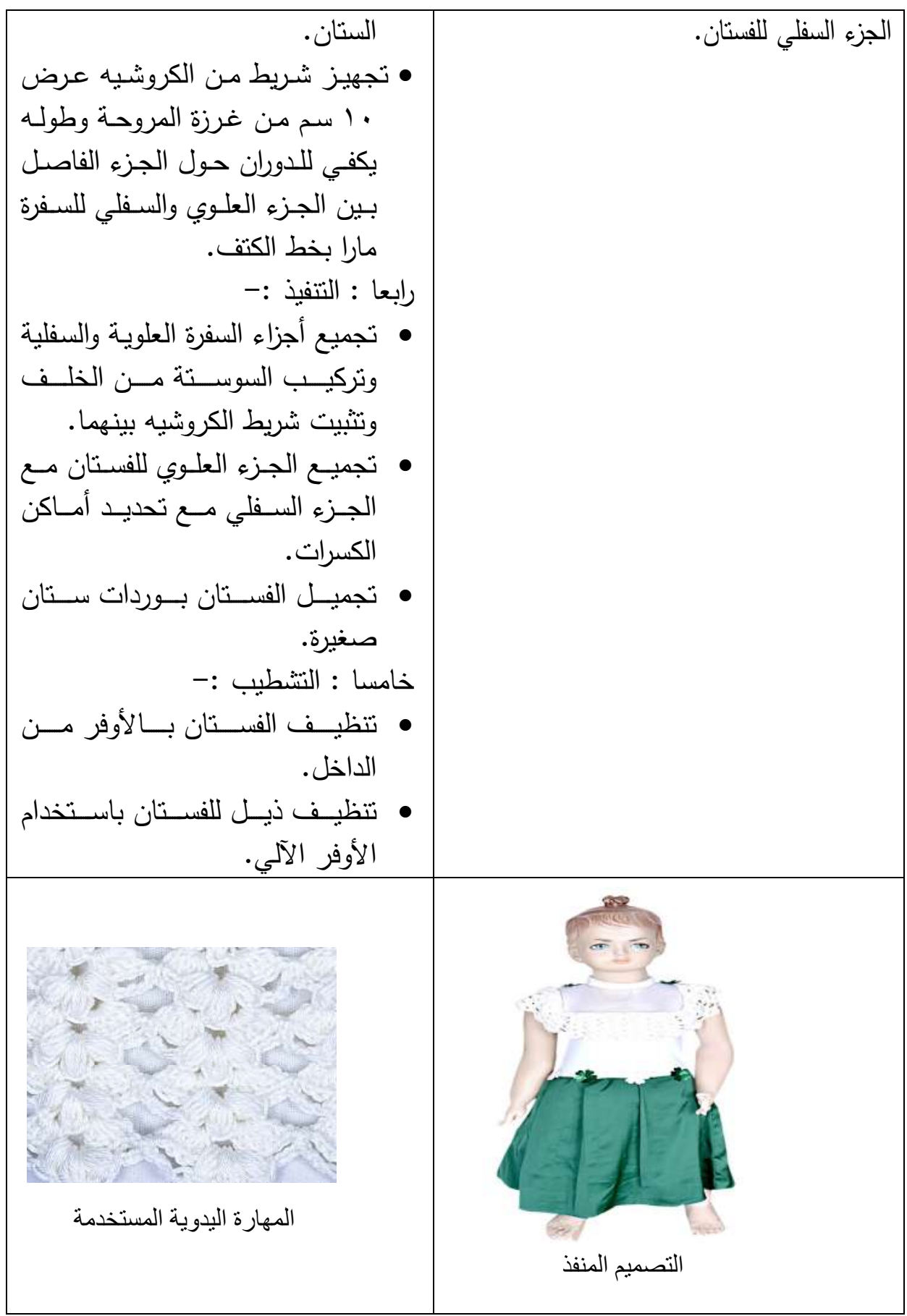




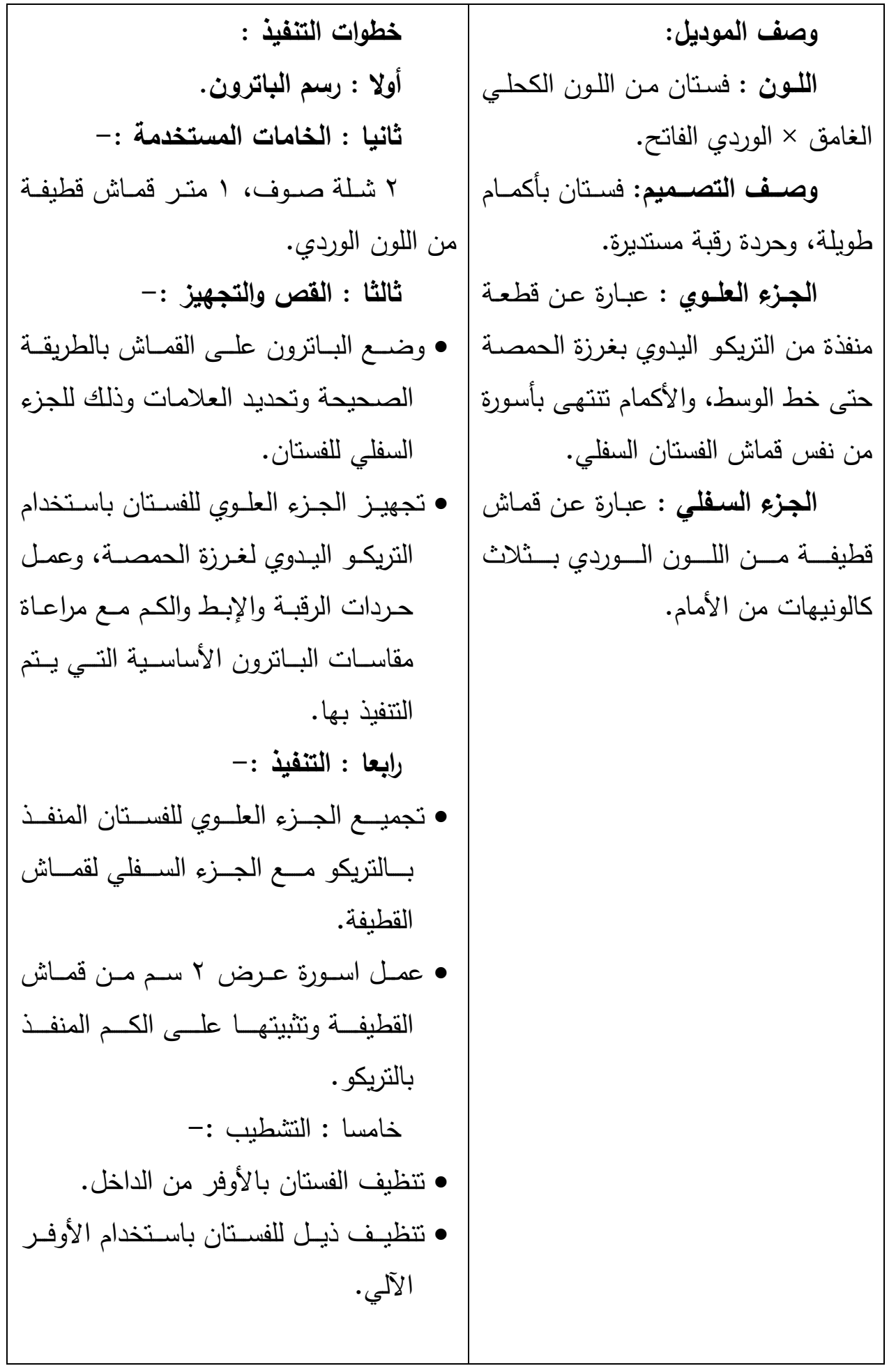




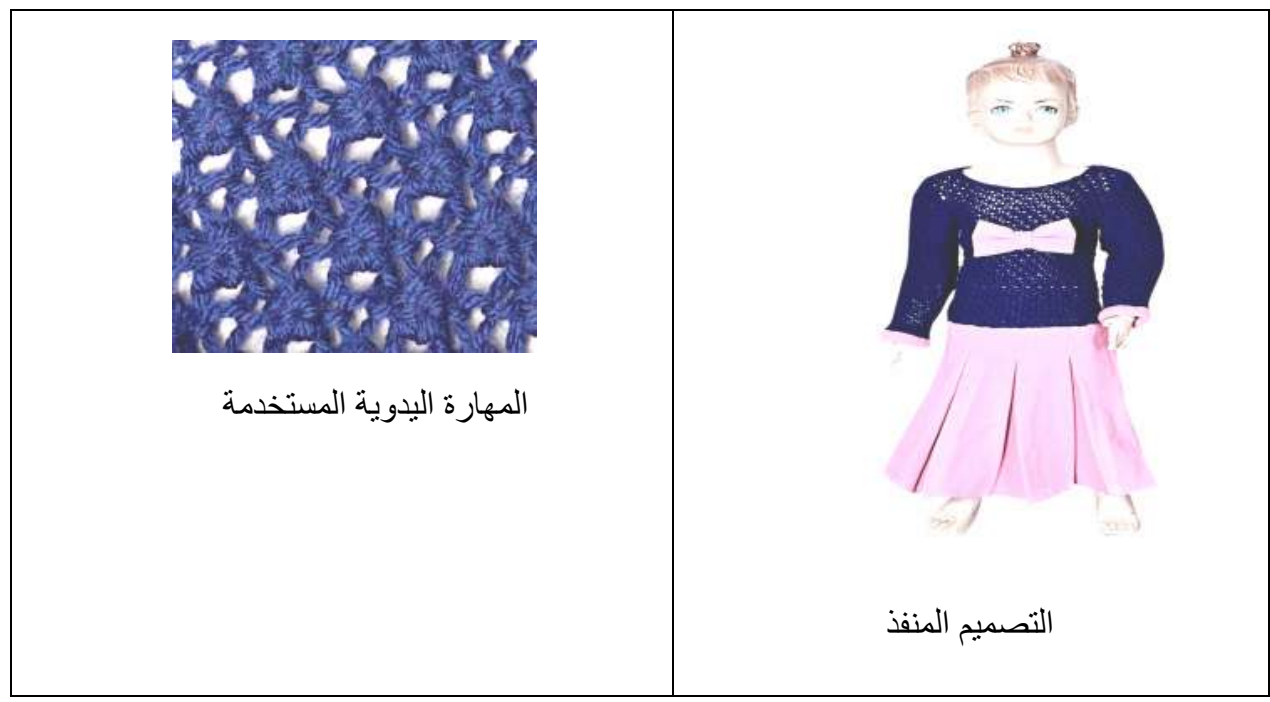

r- النسيج بالخيط :

\begin{tabular}{|c|c|}
\hline 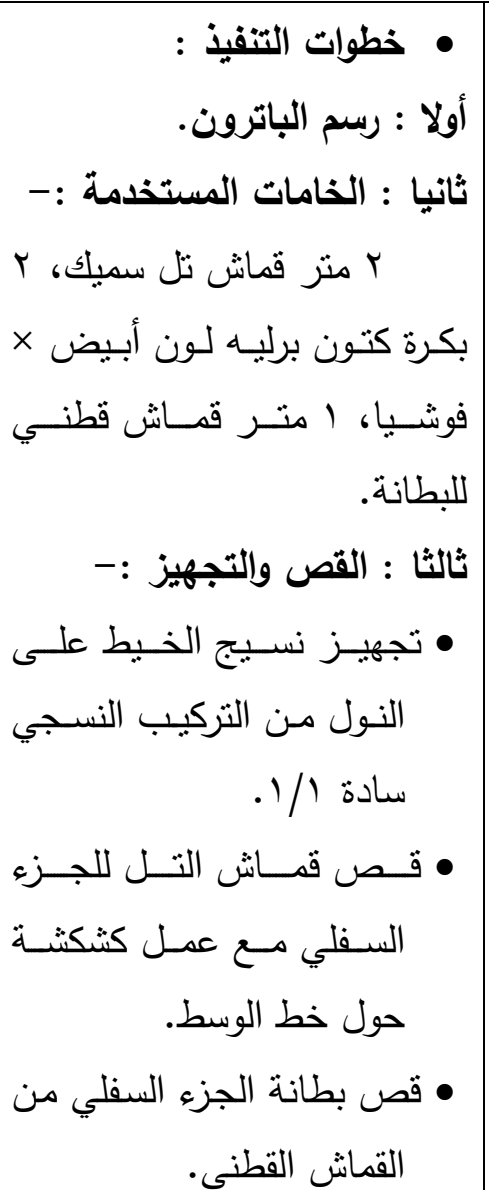 & 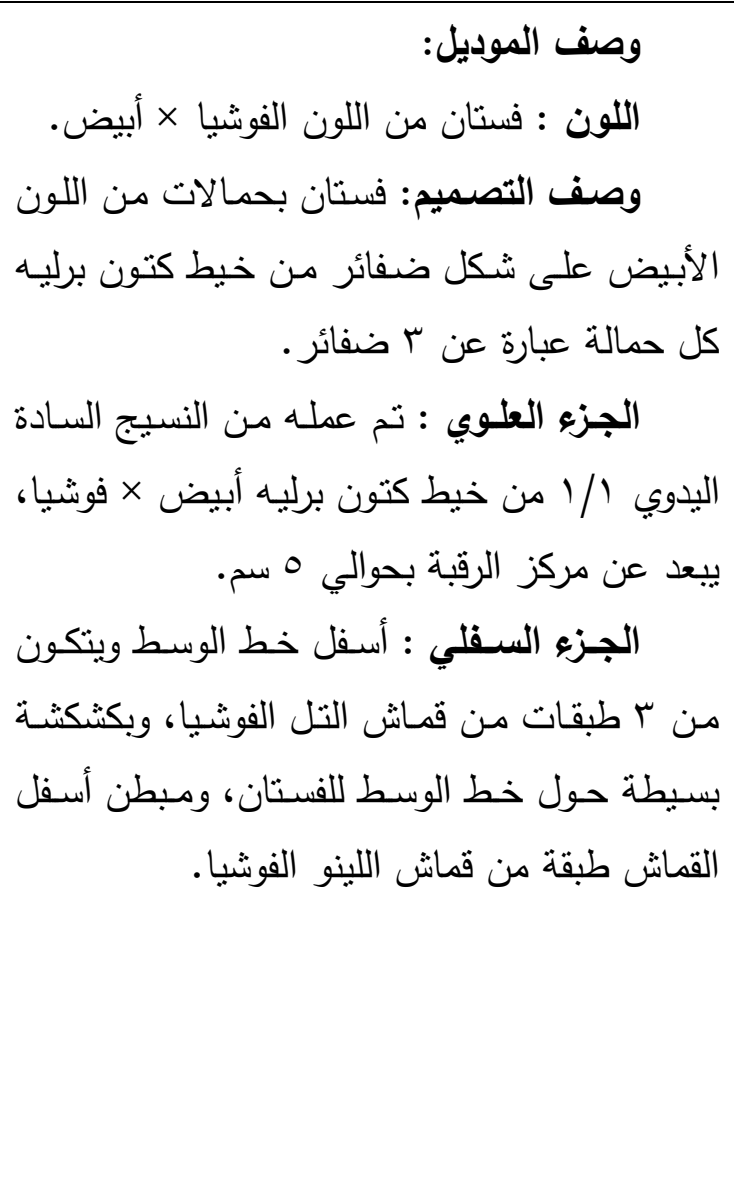 \\
\hline
\end{tabular}




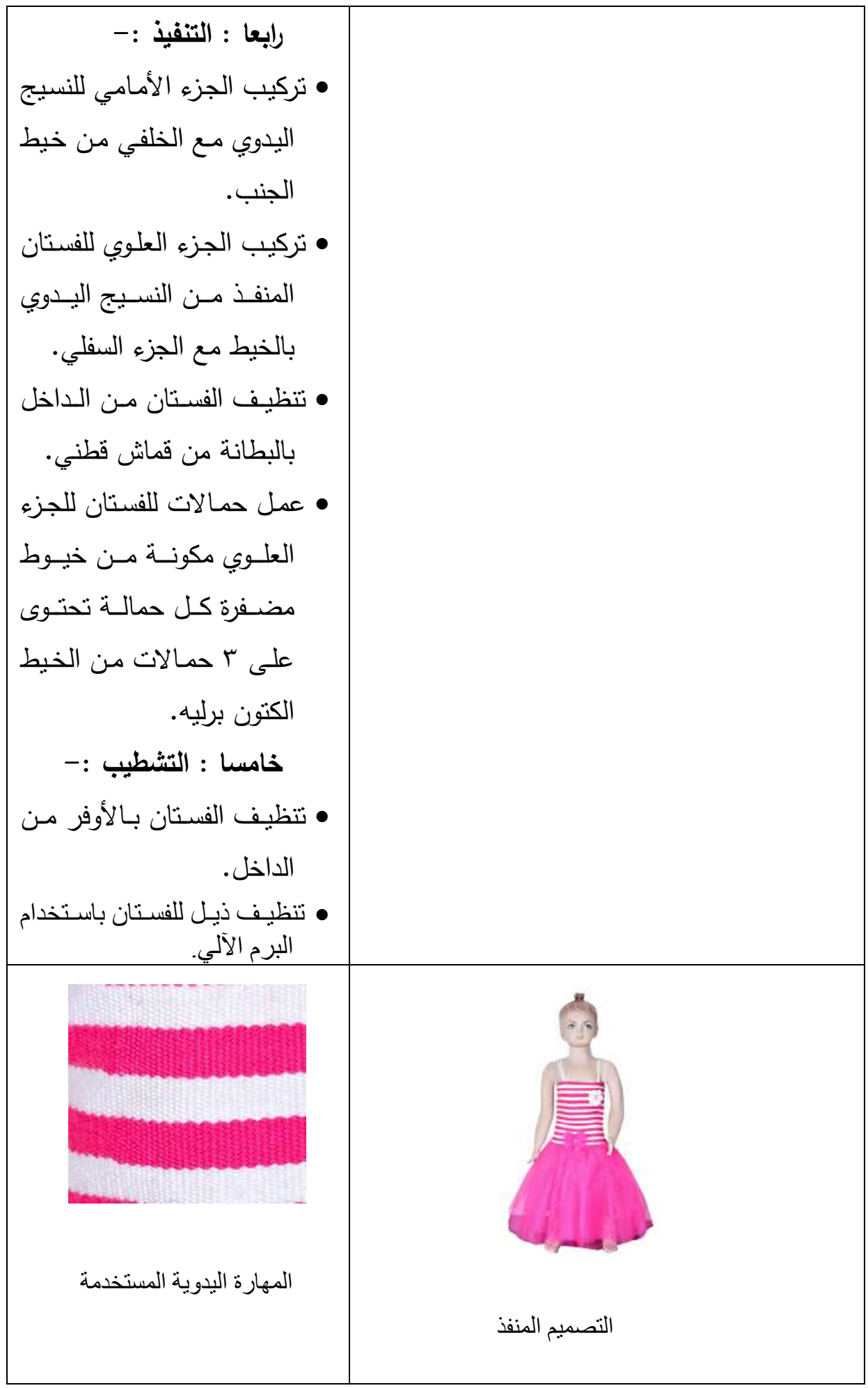


צ - النسيج بالثرائط :

$$
\begin{aligned}
& \text { خطوات التفيذ : } \\
& \text { أولا : رسم الباترون. }
\end{aligned}
$$

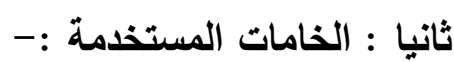

متر شيفون، متر ستان، ب بكرة ستان

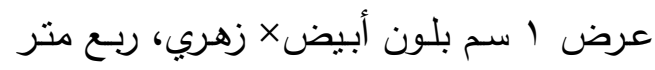

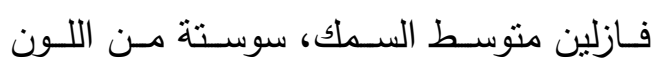

$$
\text { الزهري، متر بيه زهري. }
$$

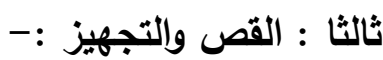

• قـــ الجـزء العلـوي مـن السـفرة للأكـام

$$
\text { والخلف من الثيفون. }
$$

• قص الدوبل كلوش الأول بقماش الثيفون الثيعون بالتساوي من كل الجهات طوله ، .ـ سم.

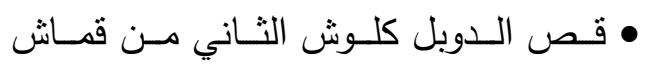

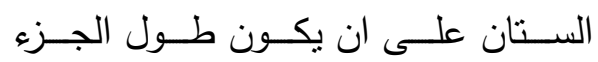
الأمامي • r سم والخلفي • ع سم.

$$
\text { رابعا : التنفيذ :- }
$$

• تركيب السفرة فى الكلوش لتقفيل الفستان. • •تظيف الفستان من الداخل بالبطانة. • بتظيف الحردات بالبيه.

خامسا : التشطيب :• تتظيف الفستان بالأوفر من الداخل. • تتظيف الأطراف السفلى للفستان ثم شرايط بالأن الستان الرفيعة للتزبين. • تزيين الفستان بحزام الستان على الوسط.

وصف التصميم: فستان بدون اكمام،

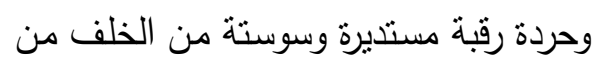
نفس لون القماش. الجزء العلـوي : مقسم لجزئين الجزء الأول من قماش الثيفون الزهري ويبعد عن

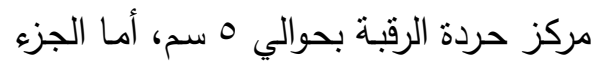

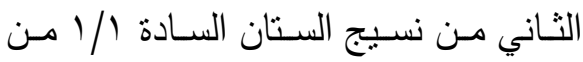

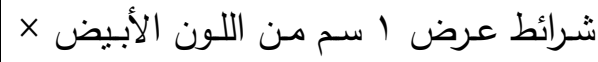

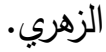

الجزيء السـلـي : يتكون من طبقتين الطبقة العلوية من قماش الساتان من اللون الزهري المتوسط السمك بحيث تكون الطبقة

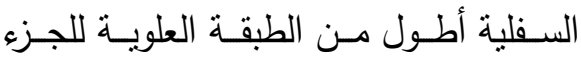
الأمامي للفستان من قماش الثيفون الزهري

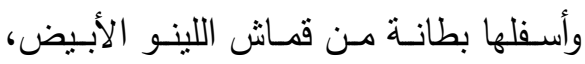
كمـا يوجد حـول خط الوسط للفستان حزام من قماش الستان الزهري يضم من الخلف بفيونكة من نفس اللون. 


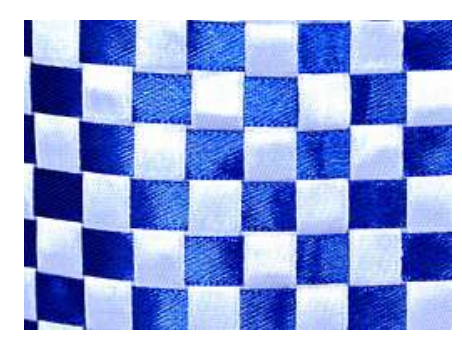

المهارة اليدوية المستخدمة

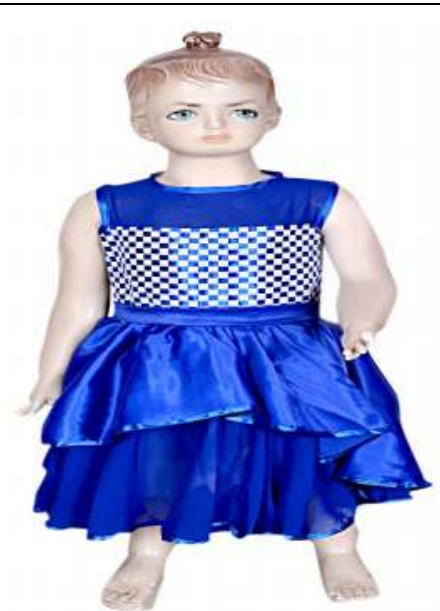

التصميم المنفذ

0- النسيج بالخرز :

\section{خطوات التنفيذ : أولا : رسم الباترون.}

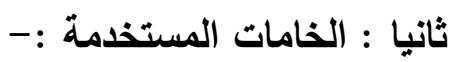
متـر ونـص قمـاش قطيفـة مـن

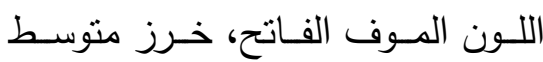
الحجـم بـألوان (أبـبض، مـوف فـاتح، موف غامق، وردي)، سوستة من نفس بـون لون القماش. ثُالثا : القص والتجهيز :وضـع البـاترون علـى القمـاش وتحديد العلامـات ثم القص بالطريقة الصحيحة. رابعا : التنفيذ :-

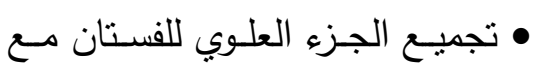
تثبيث السوستة من الخلف.

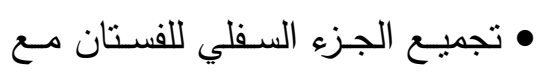
مراعاة عمل توسيعات حول خط ليط
وصف الموديل:

اللون : فستان من اللون الموف الفاتح. وصف التصميم : فستان بدون اكمام، وحردة رقبة مستديرة.

الجـزع العـــوي : عبـارة عن قمـاش القطيفـة

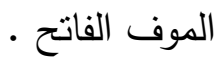
الجزيء السـقلي : من قمـاش القطيفة الموف الفاتح مي عمل توسيعات حول خط الوسط لهن

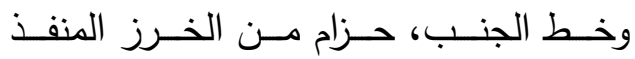
باستخدام النسـج بـالخرز على النول اليدوي

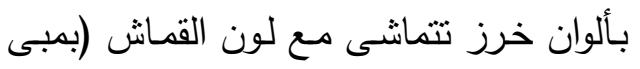
- أبيض - موف فاتح - موف غامق). 
العدد الثامن عشر ابريل 9 1 +r جr

المجلة العلمية لكلية التربية النوعية

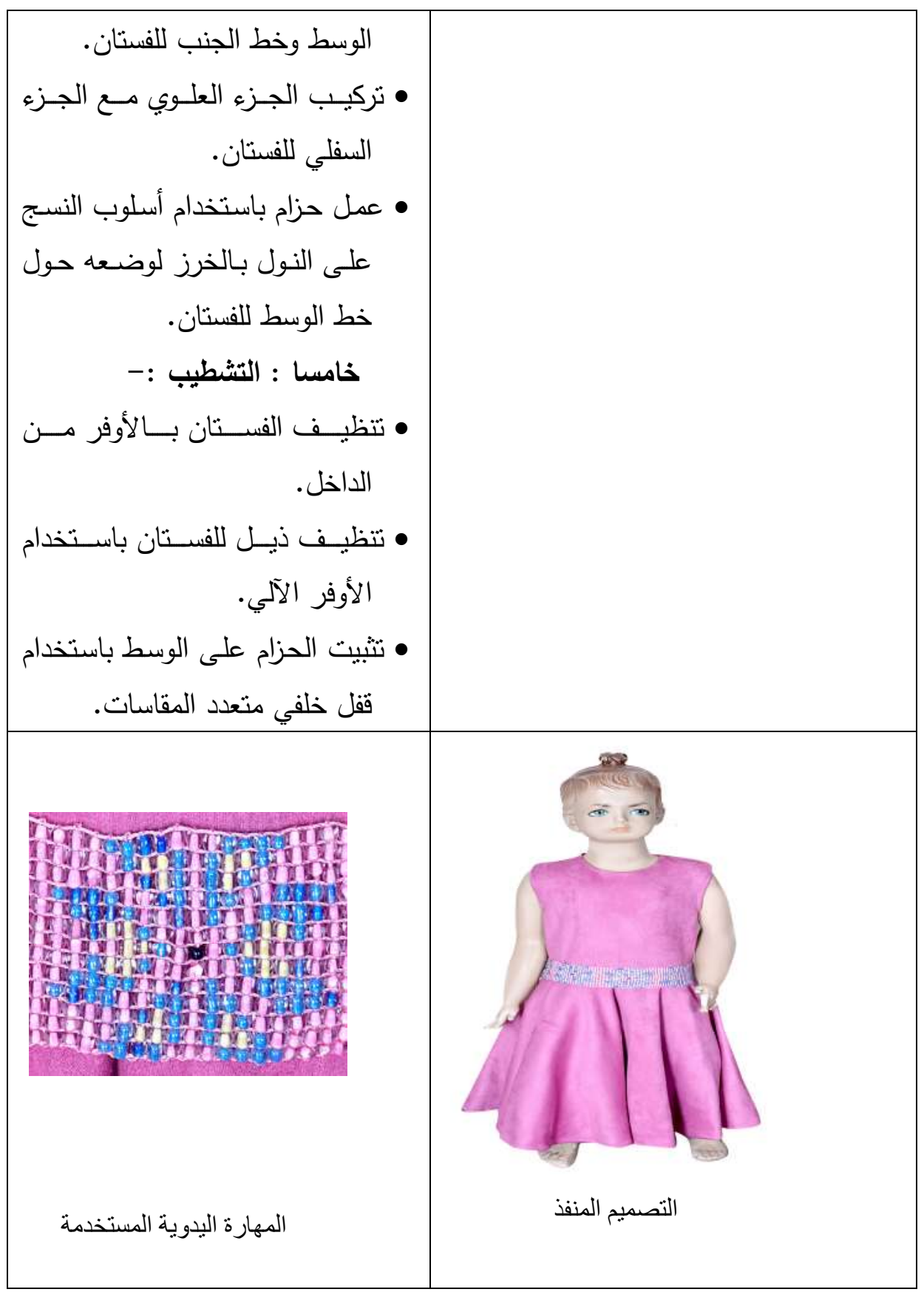




\section{يقصد به قدرة الاستيان على قياس ما وضع لقياسه .}

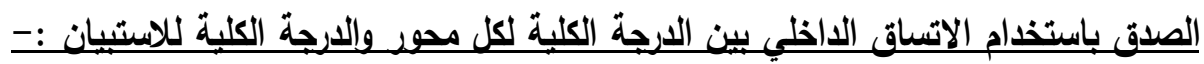

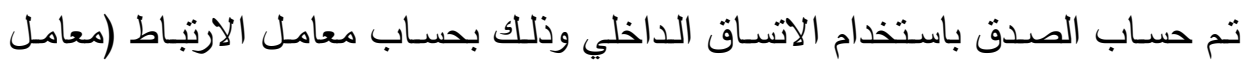

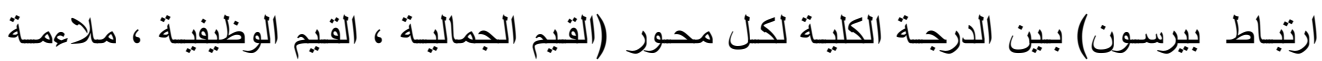

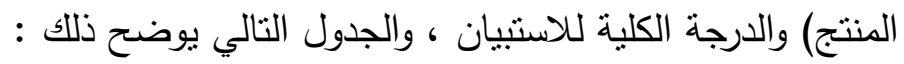
جدول ( 1 ) قيم معاملات الارتباط بين درجة كل محور ودرجة الاستبيان

\begin{tabular}{|c|c|c|}
\hline الدلالة الد & الارتباط & \\
\hline$\cdots 1$ & $\because \vee \vee \wedge$ & المحور الأول : القيم الجمالية \\
\hline$\cdots 1$ & $\cdot .9 r$ & المحور الثاني : القيم الوظيفية \\
\hline$\cdot .+1$ &. .191 & المحور الثالث : ملاعمة المنتج \\
\hline
\end{tabular}

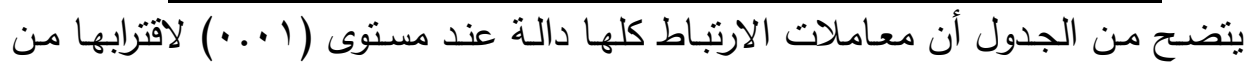
الواحد الصحيح مما يدل على صدق وتجانس محاور الاستبيان . الثبات : الثاح

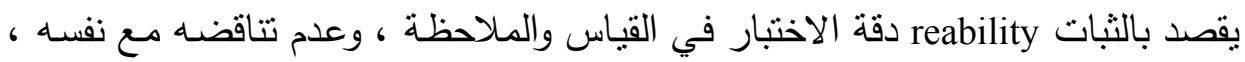

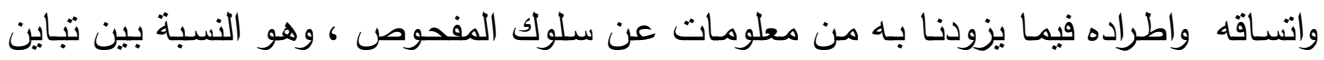

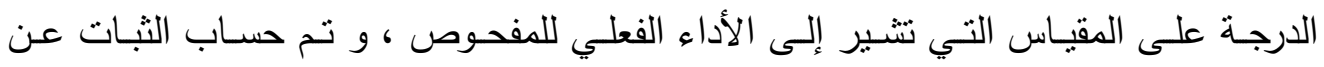
طريق:

\section{Alpha Cronbach - 1 - معامل ألفا كرونباخ:}

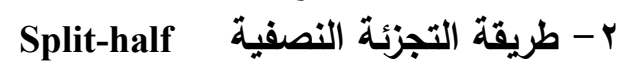

جدول ( r ) قيم معامل الثبات لمحاور الاستنيان

\begin{tabular}{|c|c|c|}
\hline التجزئة النصفية & معامل ألفا & المحاور \\
\hline$\cdot .9 r 7-\cdot . \wedge \leq r$ & $\cdot . \wedge \wedge \wedge$ & المحور الأول : القيم الجمالية \\
\hline$. . \vee 90-. . V 1 T$ & $\because .807$ & المحور الثاني : القيم الوظيفية \\
\hline$. .90 \mathrm{Y}-. .1 \mathrm{VO}$ & $.91 \leq$ & المحور الثالث : ملاءمة المنتج \\
\hline$. \wedge 0 .-. V V r$ & . & ثنات الاسنبيان ككل \\
\hline
\end{tabular}

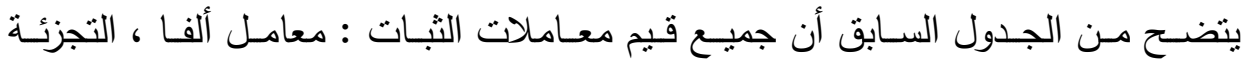

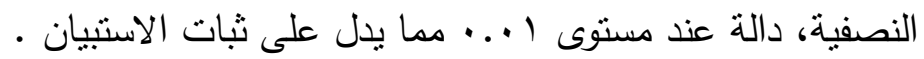




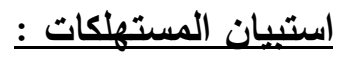

صدق الاستييان : صنينيان

يقصد به قدرة الاستبيان على قياس ما وضع لقياسه .

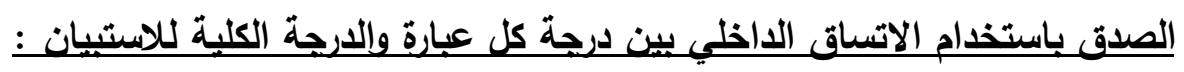

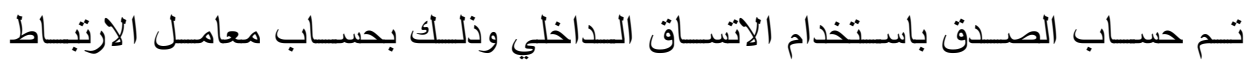

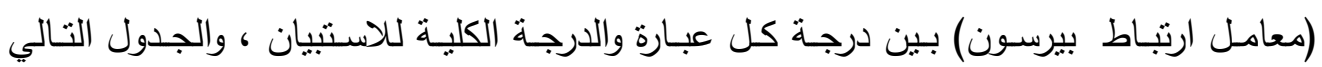
يوضح ذللك :

جدول ( ץ ) قيم معاملات الارتباط بين درجة كل عبارة ودرجة الاستبيان

\begin{tabular}{|c|c|c|}
\hline الدلالة & الارتباط & 5 \\
\hline$\ldots 1$ &.$\wedge 11$ & -1 \\
\hline$\ldots 0$ & אזT. & $-r$ \\
\hline$\ldots 1$ & .107 & r \\
\hline$\ldots 1$ & . .91r & $-\varepsilon$ \\
\hline$\ldots 1$ & .VYT & -0 \\
\hline$\ldots 1$ & $\cdot . \wedge \wedge \wedge$ & -7 \\
\hline$\ldots 0$ & $.7 \cdot V$ & $-V$ \\
\hline$\ldots 0$ & $.7 \leqslant$. & $-\Lambda$ \\
\hline$\ldots 1$ &.$\wedge r q$ & -9 \\
\hline$\ldots 1$ & זדV.. & -1 \\
\hline$\ldots 1$ & $.9 \leq 0$ & -11 \\
\hline$\ldots 1$ &.$\wedge V Y$ & $-1 T$ \\
\hline
\end{tabular}

يتضح من الجدول أن معاملات الارتباط كلها دالة عند مستوى (1 (...، ه ...) لاقترابها

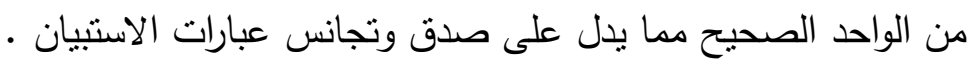

\section{الثبات :}

يقصد بالثبات reability دقة الاختبار في القياس والملاحظة، وعدم تتاقضه مع نفسه ، واتساقه واطراده فيما يزودنا بـه من معلومات عن سلوك المفحوص، وهو النسبة بين تباين الدرجة على المقياس التي تشير إلى الأداء الفعلي للمفحوص، و ونم تمن حساب الثبات عن طريق: 


\section{Alpha Cronbach - 1 - معامل ألفا كرونباخ}

\section{r - طريقة التجزئة النصفية}

جدول ( ع ) قيم معامل الثبات للاستبيان

\begin{tabular}{|l|l|l|}
\hline ثنات الاستبيان ككل & \\
\hline
\end{tabular}

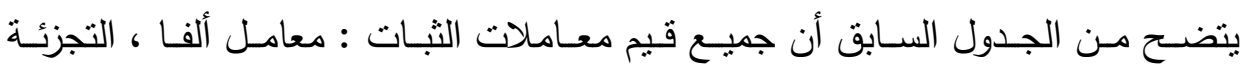
النصفية، دالة عند مستوى ا ... مما يدل على ثبات الاستبيان .

توجد فـروق ذات دلالـة إحصـائية بـين المهـارات الزخرفيـة للتصـيمات الخمس في

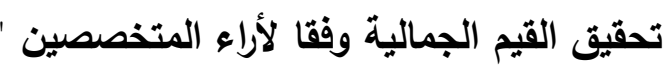

وللتحقق من هذا الفرض تم حسـاب تحليل التباين لمتوسط درجات المهارات الزخرفيـة

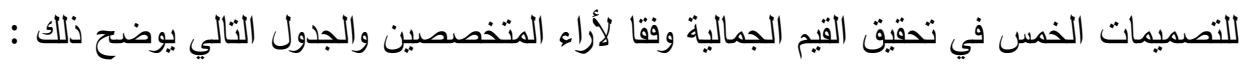

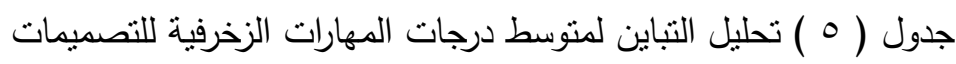

الخمس في تحقيق القيم الجمالية وفقا لأراء المتخصصين

\begin{tabular}{|c|c|c|c|c|c|}
\hline 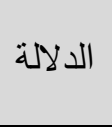 & قيمة & درجات & متوسط المربعات & المربعات & القيم الجمالية \\
\hline \multirow{3}{*}{ دال } & \multirow{2}{*}{9.011} & $\varepsilon$ & $\sum V q . . r V$ & $1917.1 \cdot V$ & بين المجموعات \\
\hline & & $\varepsilon$. & 9.771 & 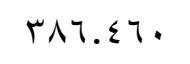 & داخل المجموعات \\
\hline & & $\varepsilon \varepsilon$ & & Tr.T.0TV & المجموع \\
\hline
\end{tabular}

يتضح من جدول ( 0 ) إن قيمة (ف) كانت (1) (9.01؟) وهى قيمة دالة إحصائيا عند

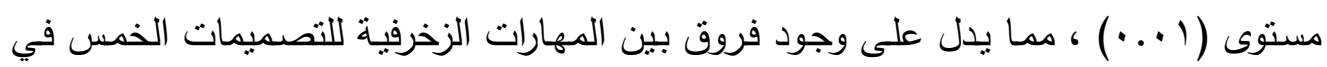
تحقيق القيم الجمالية وفقا لأراء المتخصصين. ولمعرفــة اتجـاه الدلالــة تـم تطبيـق اختبـار LSD للمقارنـات المتعـدة والجـدول التـالي يوضح ذلك : 
العدد الثامن عشر ابريل 9 1.r جr المجلة العلمية لكلية التربية النوعية

جدول ( 7 ) اختبار LSD للمقارنات المتعددة

\begin{tabular}{|c|c|c|c|c|c|}
\hline 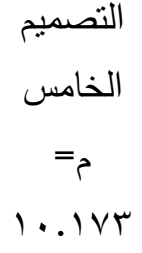 & 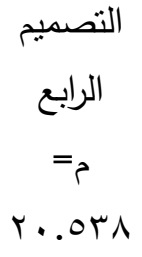 & م= الثالثمبم & الثاني & م= الأول & القيم الجمالية \\
\hline & & & & - & التصميم الأول \\
\hline & & & - & $9.9 \leq 7 * *$ & التصميم الثاني \\
\hline & & - & r.А97* & $\| . \wedge \varepsilon \Gamma^{*} * *$ & التصميم الثالث \\
\hline & - & $\Lambda .09 \leq * *$ & $\varepsilon .79 \vee * *$ & $0 . r \leqslant \Lambda * *$ & التصميم الرابع \\
\hline- & $\begin{array}{c}* * * \\
1 . .470\end{array}$ & $11.97 . * *$ & $\begin{array}{c}* * * \\
10 . .7\end{array}$ & $0.117 \% *$ & التصميم الخامس \\
\hline
\end{tabular}

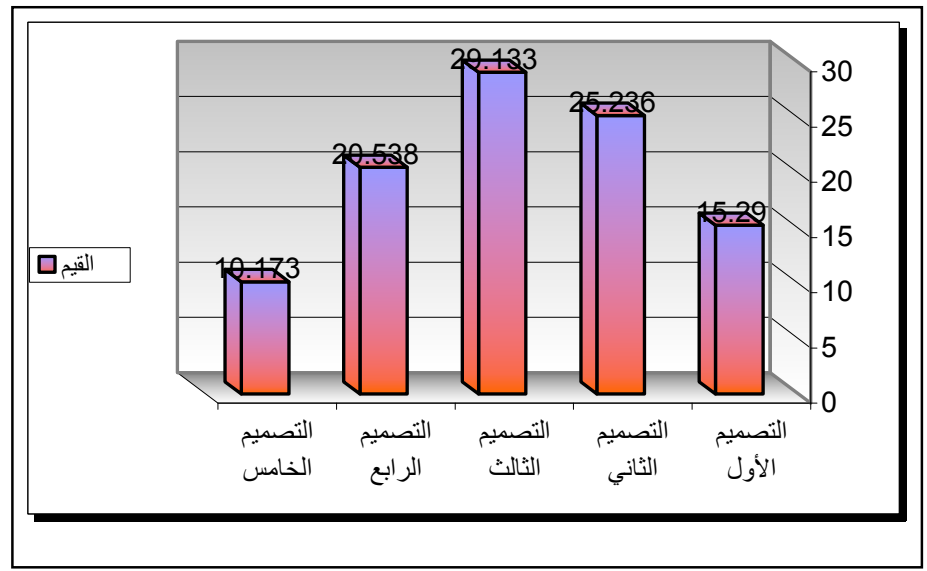

شكل ( 1 ) يوضح متوسط درجات المهارات الزخرفية للتصميمات

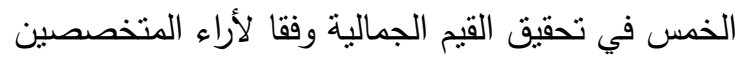

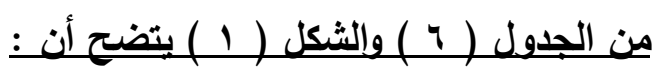

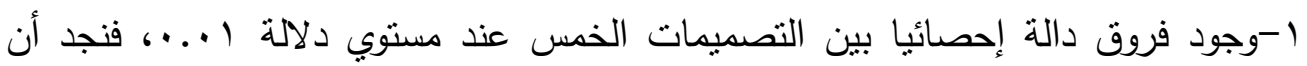
التصميم الثالث كان أفضل المهارات الزخرفية للتصميمات الخمس في تحقيق القيم الجمالية وفقا لأراء المتخصصين ، يليه التصميم الثاني ، ثم التصميم الرابع ، ثم التصميم

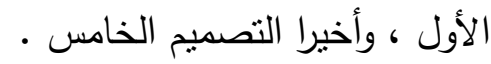


ץ-كما توجد فروق عند مستوي دلالة ه... بين التصميم الثاني والتصميم الثالث لصالح

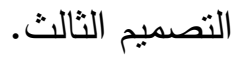

وإنما يرجـع ذلك إلى مدى ملائمسة الخامـات المستخدمة وتتاسـق ألوانها مـع الأرضية واختبار التصميم الملائم مع المنتج ودقة تتفيذ وإنهائه.

الفرض الثاني : الثيان

"توجـ فـروق ذات دلالـة إحصـائية بـين المهـارات الزخرفيـة للتصـيمات الخمس في

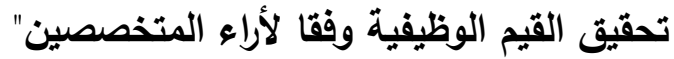

وللتحقق من هذا الفرض تم حساب تحليل التباين لمتوسط درجات المهارات الزخرفية

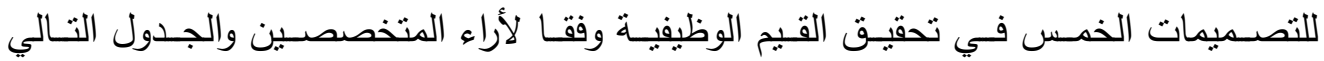
يوضح ذلك :

جدول ( V ) تحليل التباين لمتوسط درجات المهارات الزخرفية للتصميمات

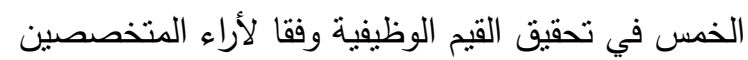

\begin{tabular}{|c|c|c|c|c|c|}
\hline الدلالة & قيمة & درجات الحرية & المربعات & المربعات & القيم الوظيفية \\
\hline \multirow{3}{*}{ ا ... } & \multirow{2}{*}{ rV.ru } & $\varepsilon$ & YOV.910 & $1.41 .94 \mathrm{~N}$ & المجموعات \\
\hline & & $\varepsilon$. & $9 . \leqslant Y T$ & rVv..09 & المجموعات \\
\hline & & $\varepsilon \varepsilon$ & & $1 \varepsilon \cdot 1.99 \mathrm{~V}$ & المجموع \\
\hline
\end{tabular}

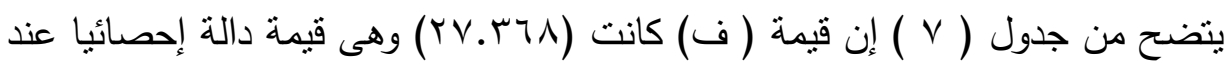
مستوى (1 ...) ، مما يدل على وجود فروق بين المهارات الزخرفية للتصميمات الخمس في تحقيق القيم الوظيفية وفقا لأراء المتخصصين. ولمعرفـة اتجـاه الدلالــة تـم تطبيـق اختبـار LSD للمقارنـات المتعـدة والجـدول التـالي يوضح ذللك : 
العدد الثامن عشر ابريل 9 بـr جr المجلة العلمية لكلية التربية النوعية

جدول ( ^ ) اختبار LSD للمقارنات المتعددة

\begin{tabular}{|c|c|c|c|c|c|}
\hline 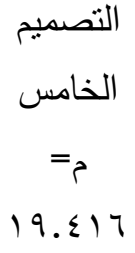 & 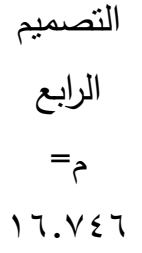 & م الثالث & م =الثانيميم & م= التصميم & القيم الوظيفية \\
\hline & & & & - & التصميم الأول \\
\hline & & & - & $r \ldots . . . r^{*}$ & التصميم الثاني \\
\hline & & - & £.17r** & V.17V** & التصميم الثالث \\
\hline & - & $1.707 * *$ & ᄀ.ร৭ณ** & ケ.乏^৭* & التصميم الرابع \\
\hline- & Y.TV.* & I К. צY ד** & $9.17 r^{*} *$ & $7.109 * *$ & التصميم الخامس \\
\hline
\end{tabular}

بدون نجوم غير دال

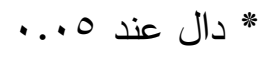

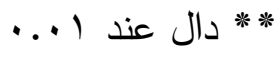

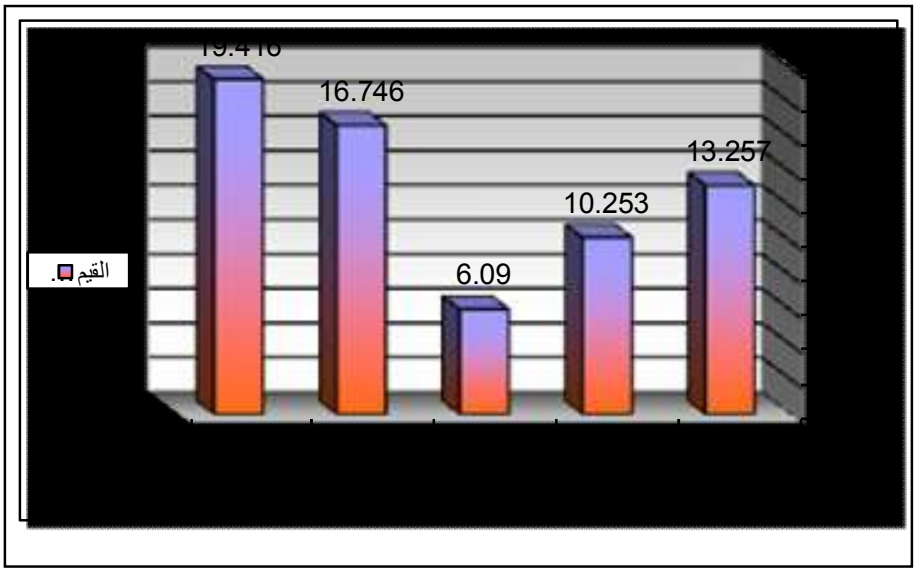

شكل ( r ) يوضح منوسط درجات المهارات الزخرفية للتصميمات

الخمس في تحقيق القيم الوظيفية وفقا لأراء المتخصصين

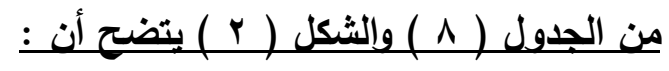

1-وجود فروق دالة إحصائيا بين التصميمات الخمس عند مستوي دلالة الـأ...، فنجد أن التصميم الخامس كان أفضل المهارات الزخرفية للتصميمات الخمس في تحقيق القيم الوظيفية وفقا لأراء المتخصصين ، يليه التصميم الرابع ، ثم التصميم الأول ، ثم التصميم الثاني ، وأخيرا التصميم الثالث. 
ץ-كما توجد فروق عند مستوي دلالة ه... بين التصميم الأول والتصميم الثاني لصالح التصميم الأول ، كما توجد فروق عند مستوي دلالة ه. .. بـ بين التصميم الأول والتصميم

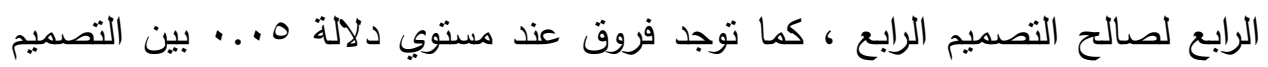
الرابع والتصميم الخامس لصالح التصميم الخامس ل

وإنما يرجع ذلك إلى مدى ملائمة الأسلوب المستخدم للفترة العمرية للطفولة المبكرة وتوافر

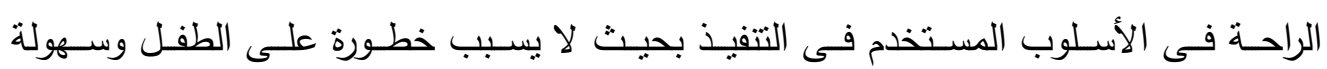
العناية به.

\section{الفرض الثالث: بالث:}

"توجد فروق ذات دلالة إحصائية بين المهارات الزخرفية للتصميمات الخمس في ملاءمة

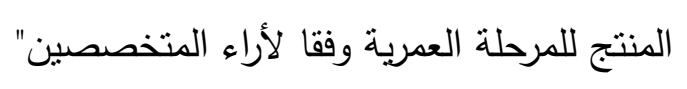

وللتحقق من هذا الفرض تم حساب تحليل التباين لمتوسط درجات المهارات الزخرفية

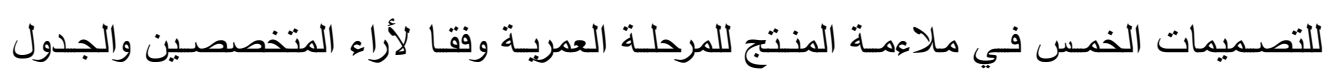
التالي يوضح ذلك :

جدول ( 9 ) ) تحليل التباين لمتوسط درجات المهارات الزخرفية للتصميمات

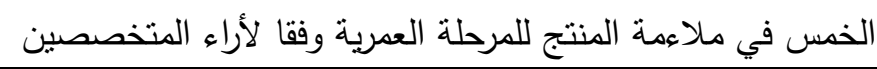

\begin{tabular}{|c|c|c|c|c|c|}
\hline الدلالة & قيمة & الحرية & متوسط المربعات & مجموع المربعات & ملاءمة المنتج \\
\hline \multirow{3}{*}{ دال } & \multirow{2}{*}{ T..TAs } & $\varepsilon$ & roo.乏VA & $1 \leq 41.911$ & بين المجموعات \\
\hline & & $\varepsilon$. & 9.79. & TAV.T10 & داخل المجموعات \\
\hline & & $\varepsilon \varepsilon$ & & $11.9 .0 Y 7$ & المجموع \\
\hline
\end{tabular}

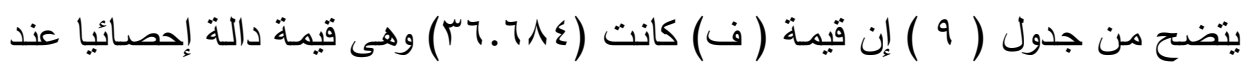

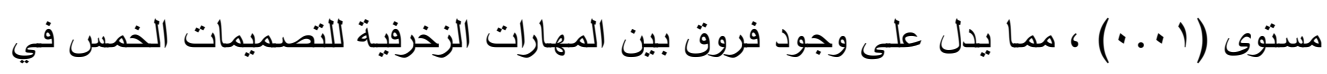

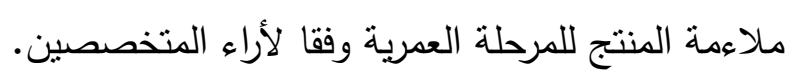

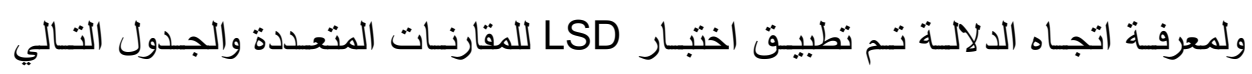
يوضح ذللك : 
العدد الثامن عشر ابريل 9 ا ب r جr المجلة العلمية لكلية التربية النوعية

جدول ( ا م اختبار LSD للمقارنات المتعددة

\begin{tabular}{|c|c|c|c|c|c|}
\hline 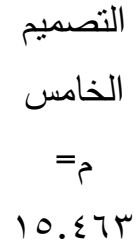 & م= التصميع & مالتالث & م= التصنيم & م= التصميم الأول & ملاءمة المنتج \\
\hline & & & & - & التصميم الأول \\
\hline & & & - & 1.イイヘフ** & التصميم الثاني \\
\hline & & - & ץ.9人ๆ* & I $\varepsilon . Y V T * *$ & التصميم الثالث \\
\hline & - & $7.1 .1 * *$ & Y.UI & ^. $\vee Y^{*} * *$ & التصميم الرابع \\
\hline- & $\varepsilon .90 * *$ & $1 . .197 * *$ & I.YI.*** & $\varepsilon . \vee \vee \neg * *$ & الخامسمبح \\
\hline
\end{tabular}

** دال عند ا +..

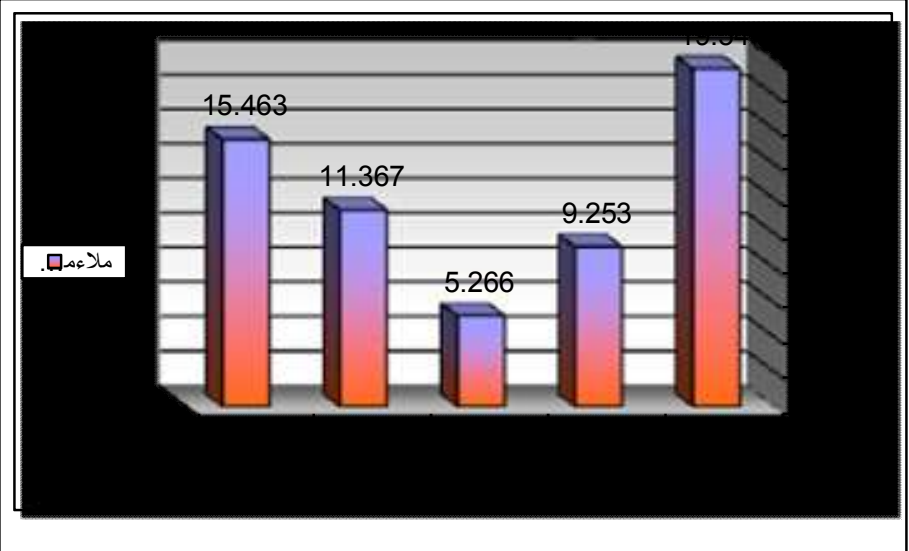

شكل ( r ) يوضح متوسط درجات المهارات الزخرفية للتصميمات الخمس في ملاعمة المنتج للمرحلة العمرية وفقا لأراء المتخصصين

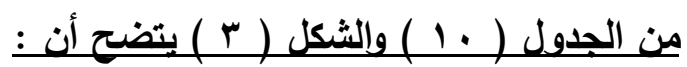

ا-وجود فروق دالة إحصائيا بين التصميمات الخمس عند مستوي دلالة ا ....، فنجد أن التصميم الأول كان أفضل المهارات الزخرفية للتصميمات الخمس في ملاعمة المنتج وفقا لأراء المتخصصين ، يليه التصميم الخامس ، ثم التصميم الرابع ، ثم التصميم الثاني ، وأخيرا التصميم الثالث . م 
ץ-كما توجد فروق عند مستوي دلالة ه... بين التصميم الثاني والتصميم الثالث لصالح التصميم الثاني ، كما توجد فروق عند مستوي دلالة ه .. . بين التصميم الثاني والتصميم

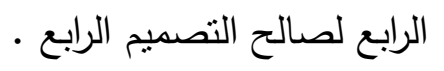

وإنما يرجع ذلك إلى مدى ملائمة المهارة المستخدمة لزخرفة ملبس الطفل لهذه المرحلة العمرية وملائمة الألوان والخامات المنفذ بها هذه المهارة وتوافر الملائمة فى الثكل العام.

الفرض الرابع :

"توجد فروق ذات دلالـة إحصـائية بين المهارات الزخرفيـة للتصميمات الخمس وفقا

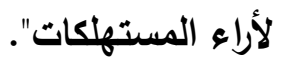

وللتحقق من هذا الفرض تم حسـاب تحليل التباين لمتوسط درجات المهارات الزخرفيـة

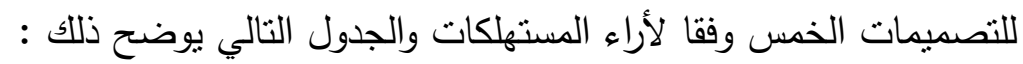
جدول ( 11 ) تحليل التباين لمتوسط درجات المهارات الزخرفية

للتصميمات الخمس وفقا لأراء المستهلكات

\begin{tabular}{|c|c|c|c|c|c|}
\hline الد اللة الة & قفيمة & درجات & المربعات & مجموع المربعات & المستهلكات \\
\hline \multirow{3}{*}{ دال } & \multirow{2}{*}{$0 . .94}$. & $\varepsilon$ & YITV.r.E & $10 \leqslant \Lambda . \wedge 10$ & بين المجموعات \\
\hline & & iv. & $\leqslant 1.97 \varepsilon$ & VIr.A & داخل المجموعات \\
\hline & & $\mid V \varepsilon$ & & $1071 \mathrm{r} .70 \mathrm{~V}$ & المجموع \\
\hline
\end{tabular}

يتضح من جدول ( 11 ) إن قيمة (ف) كانت (•rar. •0) وهى قيمة دالة إحصائيا عند مستوى (1 . . ) ، مما يدل على وجود فروق بين المهارات الزخرفية للتصميمات الخمس

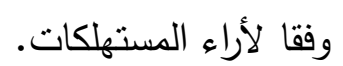

ولمعرفـة اتجـاه الدلاهـة تـم تطبيـق اختبـار LSD للمقارنـات المتعـدة والجـدول التـالي يوضح ذللك : 
العدد الثامن عشر ابريل 9 1 ب r جr

المجلة العلمية لكلية التربية النوعية

جدول ( I I ) اختبار LSD للمقارنات المتعددة

\begin{tabular}{|c|c|c|c|c|c|}
\hline م= الخامس التصميم & م= التصميم الرابع & م= الثالثميم & م= التصميم الثاني & م= التصميم الأول & المستهلكات \\
\hline & & & & - & التصميم الأول \\
\hline & & & - & IY.. $\Sigma V^{* * *}$ & التصميم الثاني \\
\hline & & - & $\varepsilon . r V \leq * *$ & $17 . \Sigma Y Y * *$ & التصميم الثالث \\
\hline & - & 19.人7ะ** & $10 . \Sigma 9 . * *$ & $r . \varepsilon \varepsilon Y^{*}$ & التصميم الرابع \\
\hline- & $1 \cdot v \leqslant 0 * *$ & $9.119 * *$ & $\varepsilon . V \varepsilon \varepsilon * *$ & $V . r \cdot r * *$ & التصميم \\
\hline
\end{tabular}

** دال عند ا +..

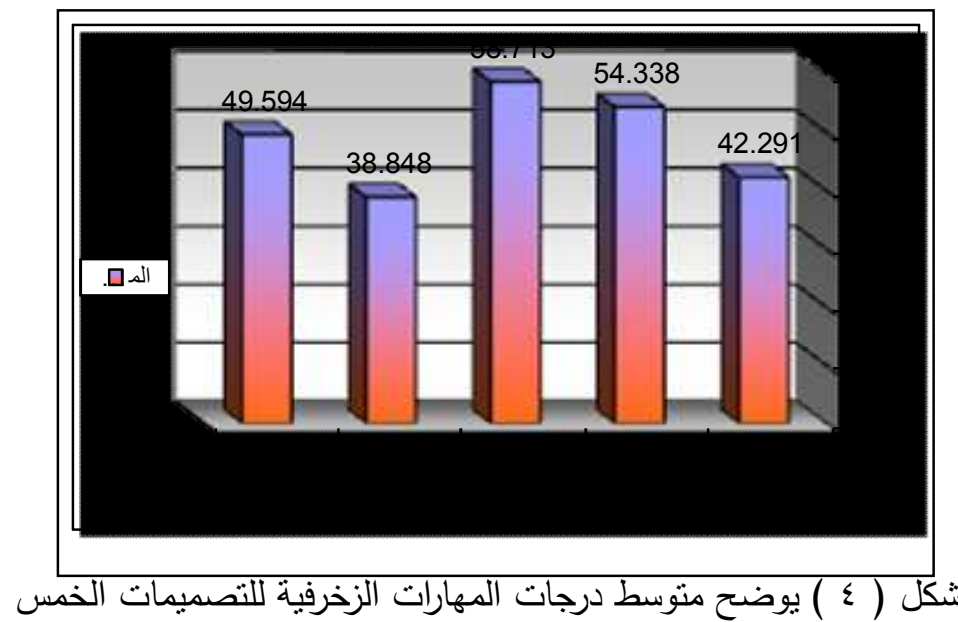

وفقا لأراء المستهكات

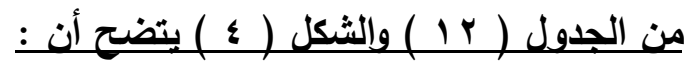

ا-وجود فروق دالة إحصائيا بين التصميمات الخمس عند مستوي دلالة ا ....، فنجد أن التصميم الثالث كان أفضل المهارات الزخرفية للتصميمات الخمس وفقا لأراء المستهكات،

يليه التصميم الثاني ، ثم التصميم الخامس ، ثم التصميم الأول ، وأخيرا التصميم الرابع. ץ-كما توجد فروق عند مستوي دلالة ه .. • بين التصميم الأول والتصميم الرابع لصالح

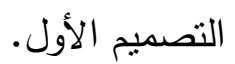

وإنمـا يرجـع ذلك إلى مدى توافر وتحقق قدرة الطفل على مزاولة أنشطته للتصـيمات المنفذة وأيضا تحقق سهولة ارتداء الملبس وتحقق الجودة فى التفيذ والتشطيب. 
"توجد فروق ذات دلالة إحصائية بين المهارات البنائية للتصميمات الخمس في تحقيق القيم الجمالية وفقا لأراء المتخصصين". وللتحقق مـن هذا الفرض تم حسـاب تحليل التباين لمتوسط درجـات المهارات البنائيـة

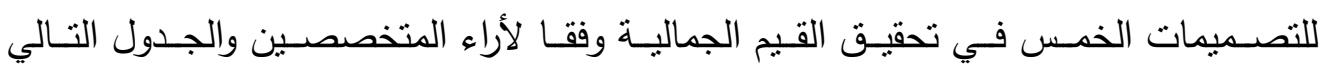
يوضح ذللك : جدول ( T T ) تحليل التباين لمتوسط درجات المهارات البنائية للتصميمات الخمس في تحقيق القيم الجمالية وفقا لأراء المتخصصين

\begin{tabular}{|c|c|c|c|c|c|}
\hline الدلالة & قيمة & الحربة & متوسط المربعات & مجموع المربعات & القيم الجمالية \\
\hline \multirow{3}{*}{ دال } & \multirow{2}{*}{ \&T.ATr } & $\varepsilon$ & T T T & IE. r. $\leqslant q r$ & بين المجموعات \\
\hline & & $\varepsilon$. & $V .999$ & r $9.9 \vee r$ & داخل المجموعات \\
\hline & & $\varepsilon \varepsilon$ & & IVYY.ETT & المجموع \\
\hline
\end{tabular}

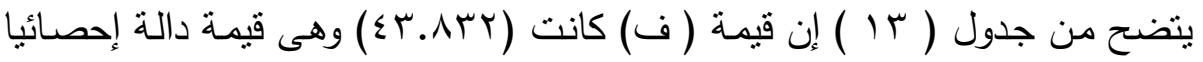

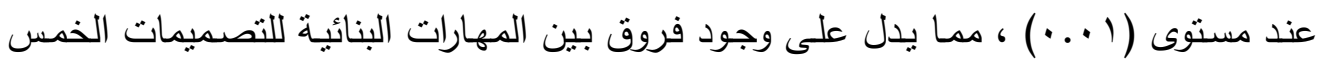
في تحقيق القيم الجمالية وفقا لأراء المتخصصين. ولمعرفة اتجاه الدلالة تم تطبيق اختبار LSD للمقارنات المتعددة والجدول التالي يوضح

جدول ( \& 1 ) اختبار LSD للمقارنات المتعددة

\begin{tabular}{|c|c|c|c|c|c|}
\hline 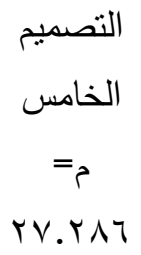 & 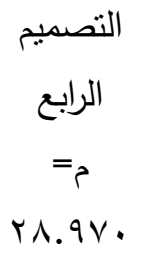 & م= الثالث & م= التصميم & م= التصميم & القيم الجمالية \\
\hline & & & & - & التصميم الأول \\
\hline & & & - & 0. Ү৭૫** & التصميم الثاني \\
\hline & & - & $9 . \Gamma 10 * *$ & $\varepsilon \ldots 1 \wedge * *$ & التصميم الثالث \\
\hline & - & $7 . \leq 0 \leq * *$ & 10.VV.** & 1.. $\Sigma V Y * * *$ & التصميم الرابع \\
\hline- & 1.7人 & $\varepsilon . \vee \vee \backslash * *$ & $1 \varepsilon \ldots \wedge \neg * *$ & 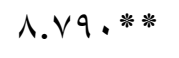 & التصميم الخامس \\
\hline
\end{tabular}


العدد الثامن عشر ابريل 9 1 ب r جr

المجلة العلمية لكلية التربية النوعية

$$
\text { ** دال عند ا •. }
$$

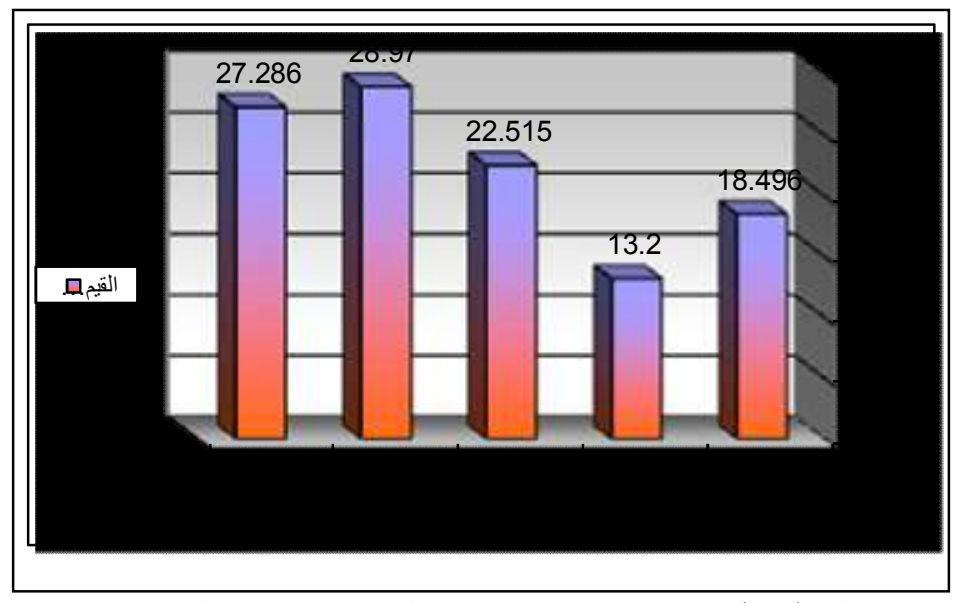

شكل ( 0 ) يوضح متوسط درجات المهارات البنائية للتصميمات

الخمس في تحقيق القيم الجمالية وفقا لأراء المتخصصين

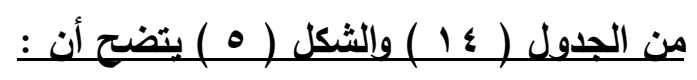

ا-وجود فروق دالة إحصائيا بين التصميمات الخمس عند مستوي دلالة ا +...، فنجد أن التصميم الرابع كان أفضل المهارات البنائية للتصميمات الخمس في تحقيق القيم الجمالية وفقا لأراء المتخصصين ، يليه التصميم الخامس ، ثم التصميم الثالث ، ثم التصميم الأول ، وأخيرا التصميم الثاني .

r-بينما لا توجد فروق بين التصميم الرابع والتصميم الخامس •

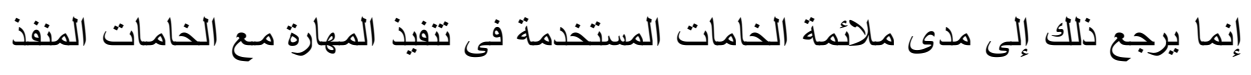

بها المنتج ككل وتتاسق الألوان بينهما. الفرض السادس :

"توجد فروق ذات دلالة إحصائية بين المهارات البنائية للتصميمات الخمس في تحقيق القيم الوظيفية وفقا لأراء المتخصصين".

وللتحقق من هذا الفرض تم حسـاب تحليل التباين لمتوسط درجـات المهارات البنائيـة للتصميمات الخمس في تحقيق القيم الوظيفية وفقا لأراء المتخصصين والجدول التالي يوضح ذللك : 
العدد الثامن عشر ابريل 9 1 ب r جr

جدول ( 10 ) تحليل التباين لمتوسط درجات المهارات البنائية للتصميمات الخمس في تحقيق القيم الوظيفية وفقا لأراء المتخصصين دئنين

\begin{tabular}{|c|c|c|c|c|c|}
\hline الد لالة & قيمة & درجات & متوسط المربعات & المربعات & القيم الوظيفية \\
\hline \multirow{2}{*}{ ו ... دال } & \multirow{2}{*}{ דצ.TYT } & $\varepsilon$ & צדיטאי & $\mid \pi \leq 1 . \leqslant \leq \wedge$ & بين المجموعات \\
\hline & & $\varepsilon$. & $1 . r \vee q$ & $\leqslant 11.10 \leqslant$ & داخل المجموعات \\
\hline & & $\varepsilon \varepsilon$ & & IVOr.T.r & المجموع \\
\hline
\end{tabular}

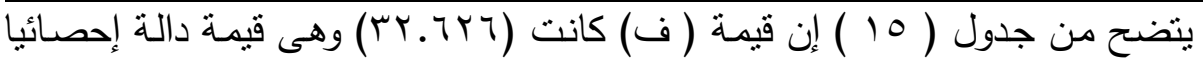

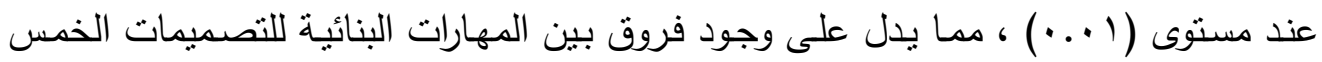

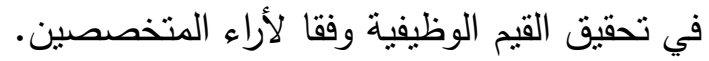
ولمعرفة اتجاه الدلالة تم تطبيق اختبار LSD للمقارنات المتعددة والجدول التالي يوضـح

جدول ( 17 ) اختبار LSD للمقارنات المتعددة

\begin{tabular}{|c|c|c|c|c|c|}
\hline 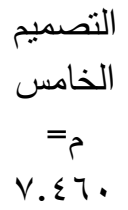 & م= التصميم & التصميم الثالث & م= التصاني & م=التحكيم الأول & القيم الوظيفية \\
\hline & & & & - & التصميم الأول \\
\hline & & & - & У.ヘルฯ** & التصميم الثاني \\
\hline & & - & Y.AIY* & O..Y.*** & التصميح الثالث \\
\hline & - & 11.Vor** & $1 \leqslant .0 \mathrm{~V} . * *$ & ᄀ.VTr** & التصميم الرابع \\
\hline- & $r . V \leqslant 7^{*}$ & $9 . \ldots 7 * *$ & И.Аイr*** & r.9人ฯ* & التصميم الخامس \\
\hline
\end{tabular}

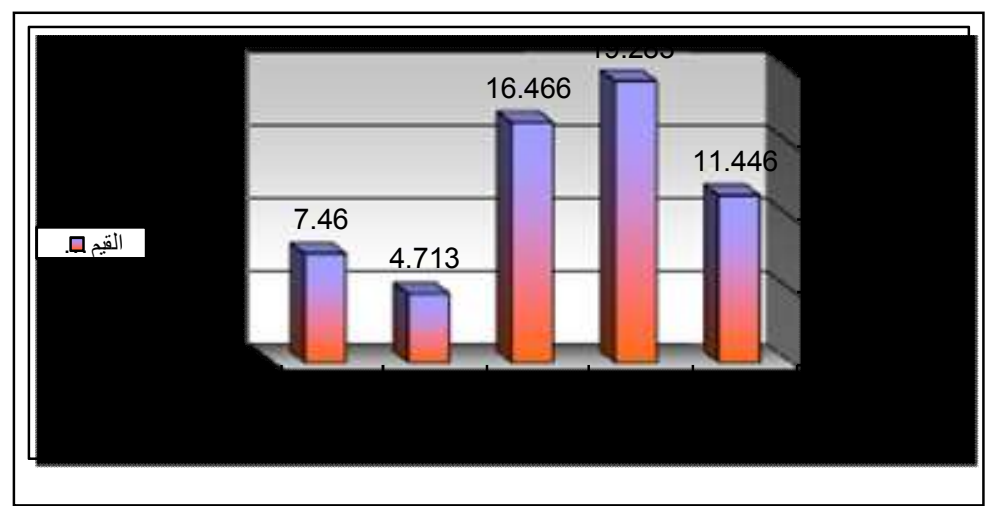

شكل ( 7 ) يوضح متوسط درجات المهارات البنائية للتصميمات

الخمس في تحقيق القيم الوظيفية وفقا لأراء المتخصصين 


\section{من الجدول (17 ) والثكل (7 ) بتضح أن :}

1-وجود فروق دالة إحصائيا بين التصميمات الخمس عند مستوي دلالة ا ...، فنجد أن التصميم الثاني كان أفضل المهارات البنائية للتصميمات الخمس في تحقيق القيم الوظيفية

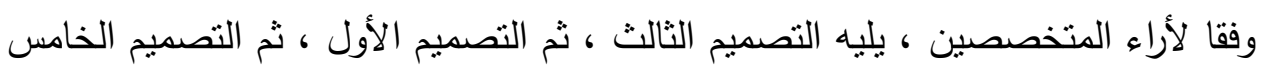

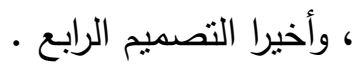

ץ-كما توجد فروق عند مستوي دلالة ه ... بين التصميم الأول والتصميم الخامس لصالح التصميم الأول ، كما توجد فروق عند مستوي دلالة ه ه... بين التصميم الثاني والتصميم

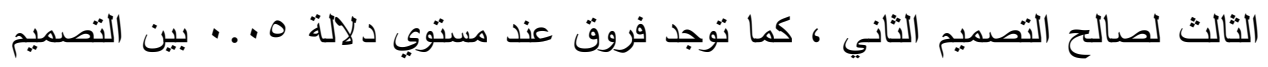

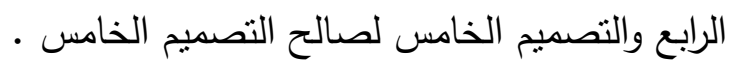
وإنما يرجع ذلك إلى مدى نوافر الراحة فى المنتج المنفذ باستخدام المهارة اليدوية ولا يمثل خطورة للطفل من الارتداء وسهولة العناية بالملبس.

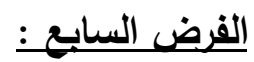

"توجــ فروق ذات دلالــة إحصـائية بـين المهـارات البنائيـة للتصـميمات الخمس في ملاعمة المنتج للمرحلة العمرية وفقا لأراء المتخصصين". وللتحقق من هذا الفرض تم حسـاب تحليل التباين لمنوسط درجات المهارات البنائية

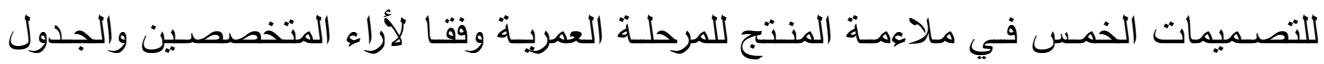

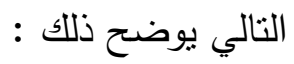
جدول ( V ) تحليل التباين لمتوسط درجات المهارات البنائية للتصميمات

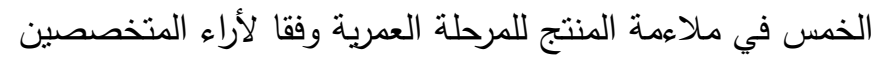

\begin{tabular}{|c|c|c|c|c|c|}
\hline الدلالة & قيمة & درجات & متوسط & مجموع المربعات & ملاعمة المنتج \\
\hline \multirow{3}{*}{ ا +... } & \multirow{3}{*}{ rᄉ. 791} & $\varepsilon$ & roq.rqs & $1 \leq r V .1 V T$ & بين المجموعات \\
\hline & & $\varepsilon$. & Ir.Or. & $0 \ldots v 97$ & داخل المجموعات \\
\hline & & $\varepsilon \varepsilon$ & & I9rV. $9 v \mathrm{r}$ & المجموع \\
\hline
\end{tabular}

يتضح من جدول (V ) إن قيمة ( ف) كانت (Y.791) وهى قيمة دالة إحصائيا عند

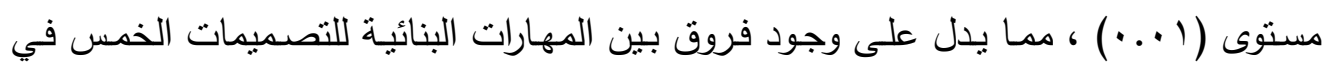

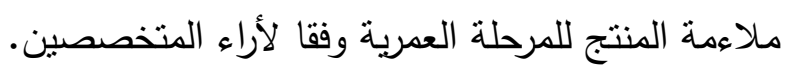


ولمعرفة اتجاه الدلالة تم تطبيق اختبار LSD للمقارنات المتعددة والجدول التالي يوضح

جدول ( l ) اختبار LSD للمقارنات المتعددة

\begin{tabular}{|c|c|c|c|c|c|}
\hline 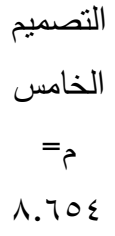 & 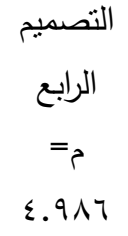 & م= التصميم الثالث & م=تسبميم الثاني & م= التصميم الأول & ملاعمة المنتج \\
\hline & & & & - & التصميم الأول \\
\hline & & & - & Ү.乏ऍ人* & التصميم الثاني \\
\hline & & - & ᄀ. rร.*** & $\Gamma . \wedge .1 *$ & التصميم الثالث \\
\hline & - & 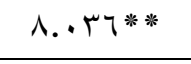 & $1 \leq . Y \vee \neg * *$ & 11.АrV** & التصميم الرابع \\
\hline- & ケ.างV* & 乏.นฯ人** & $1 \cdot .7 \cdot 1 * *$ & A.IV.*** & التصميم الخامس \\
\hline
\end{tabular}

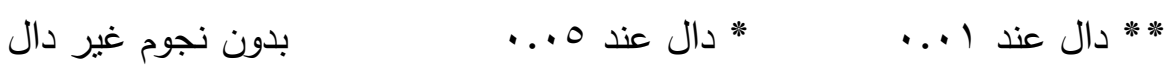

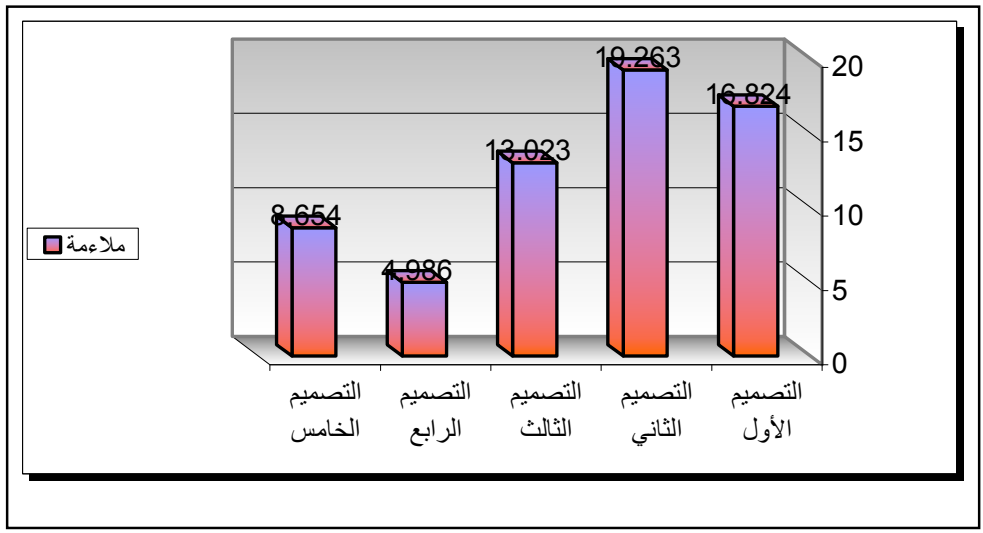

شكل ( V ) يوضح متوسط درجات المهارات البنائية للتصميمات

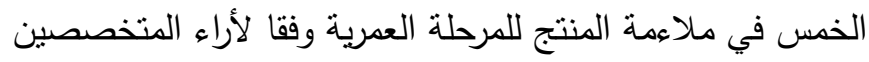

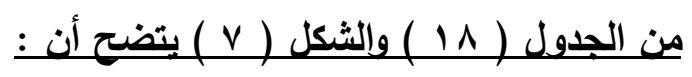

1-وجود فروق دالة إحصائيا بين التصميمات الخمس عند مستوي دلالة ا +...، فنجد أن التصميم الثاني كان أفضل المهارات البنائية للتصميمات الخمس في ملاعمة المنتج وفقا

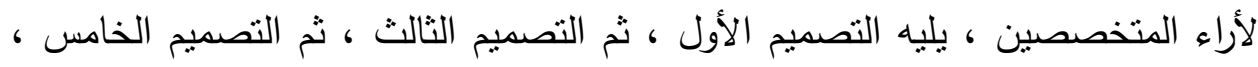
وأخيرا التصميم الرابع • 
r-كما توجد فروق عند مستوي دلالة ه... بين التصميم الأول والتصميم الثاني لصالح التصميم الثاني ، كما توجد فروق عند مستوي دلالة ه . . ب بين التصميم الأول والتصميم الثالث لصالح التصميم الأول ، كما توجد فروق عند مستوي دلالة هـ هـ .ببين التصميم

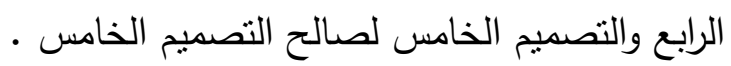
وإنما يرجع ذلك إلى مدى ملائمة المهارة المستخدمة لملابس الطفل فى المرحلة المبكرة

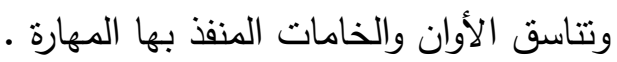
القرض الثامن : "توجد فروق ذات دلالة إحصائية بين المهارات البنائية للتصميمات الخمس وفقا لأراء

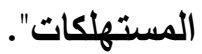
وللتحقق مـن هذا الفرض تم حسـاب تحليل التباين لمتوسط درجـات المهارات البنائيـة للتصميمات الخمس وفقا لأراء المستهلكات والجدول التالي يوضح ذللك : جدول ( 9 ( ) تحليل التباين لمتوسط درجات المهارات البنائية للتصميمات الخمس وفقاء لأراء المستهلكات

\begin{tabular}{|c|c|c|c|c|c|}
\hline الدلالة & قيمة & درجات & المربعات & مجموع المربعات & المستهلكات \\
\hline \multirow{3}{*}{ ני د... } & \multirow{2}{*}{ שד } & $\varepsilon$ & $r \leq q r .1 T$. & Ir971.0rT & بين المجموعات \\
\hline & & IV. & $07.0 \leqslant 1$ & $9711.7 \leq 0$ & داخل المجموعات \\
\hline & & $I V \varepsilon$ & & TrON..STY & المجموع \\
\hline
\end{tabular}

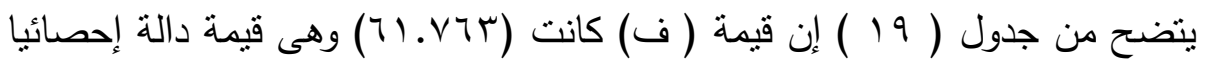
عند مستوى (1 ...) ، مما يدل على وجود فروق بين المهارات البنائية للتصميمات الخمس الته وفقا لأراء المستهلكات. ولمعرفة اتجاه الدلالة تم تطبيق اختبار LSD للمقارنات المتعددة والجدول التالي يوضح 
العدد الثامن عشر ابريل 9 1 ب r جr

المجلة العلمية لكلية التربية النوعية

جدول ( · r ) اختبار LSD للمقارنات المتعددة

\begin{tabular}{|c|c|c|c|c|c|}
\hline 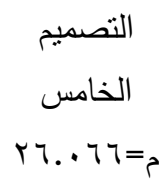 & 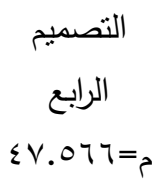 & م= التصميم الثالث & م التصميم & 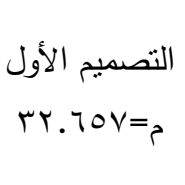 & ملاعمة المنتج \\
\hline & & & & - & التصميم الأول \\
\hline & & & - & А. ケヘケ** & التصميم الثاني \\
\hline & & - & $\begin{array}{c}*_{*} \\
|. r Y V|\end{array}$ & $11.00 \leqslant * *$ & التصميم الثالث \\
\hline & - & r. $7 \leqslant 0 *$ & フ.フイフ** & $1 \leq .9 .9 * *$ & التصميم الرابع \\
\hline- & $\begin{array}{c}* * \\
\text { Y). } 299\end{array}$ & $\begin{array}{c}* * \\
\text { Y0.1 } \varepsilon \varepsilon\end{array}$ & $\begin{array}{c}* * \\
\mid \varepsilon . \wedge \vee r\end{array}$ & $7.09 . * *$ & التصميم الخامس \\
\hline
\end{tabular}

* * *ال عند ا +..

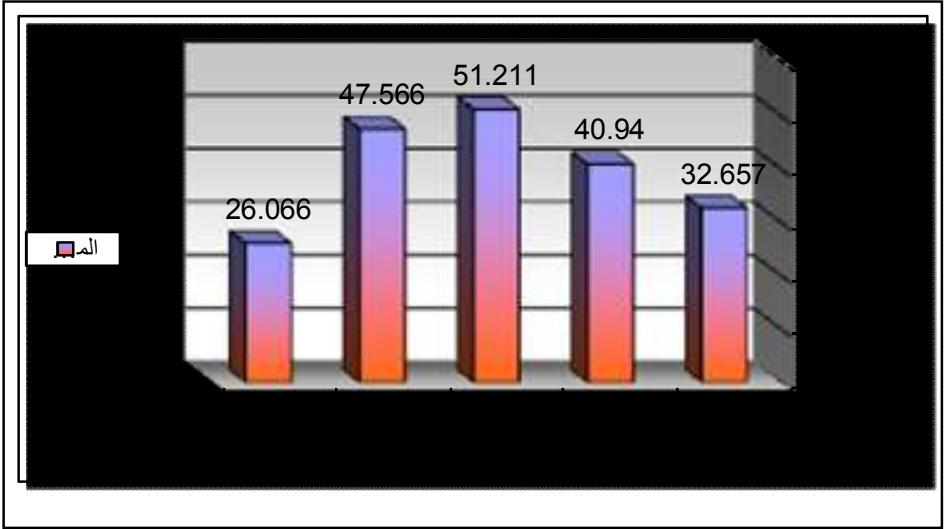

شكل ( ^ ) يوضح متوسط درجات المهارات البنائية للتصميمات الخمس

وفقا لأراء المستهكات

من الجدول ( r r ) والشكل ( ) ) يتضع أن :

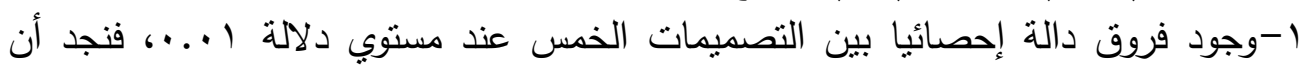

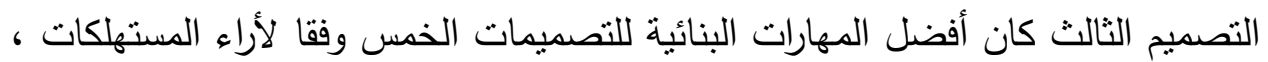

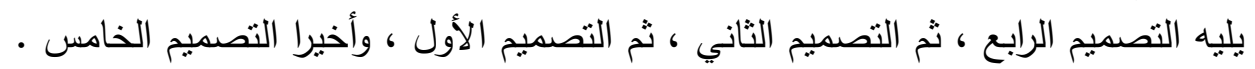
ץ-كما توجد فروق عند مستوي دلالة ه . . بين التصميم الثالث والتصميم الرابع لصالح التصميم الثالث. وإنمـا برجه ذلك إلى مـدى تحقق الموضـة فى التصـيم المنفذ وملاعمتـه مـن الألكوان والخامات مع بعضها البعض. 


\section{الفرض التاسع :}

" توجد جدوى اقتصادية من استخدام المهارات اليدوية فى تنفيذ ملابس أطفال المرحلة المبكرة.

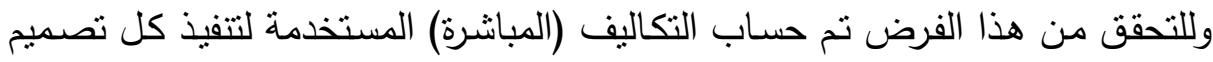

باستخدام المهارات اليدوية الزخرفية والبنائية لملابس أطفال المرحلة المبكرة وهى كالتالي :-

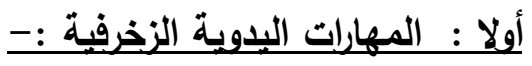

$$
\begin{aligned}
& 1 \text { - الموديل الأول :- }
\end{aligned}
$$

\begin{tabular}{|c|c|c|}
\hline السعر / جنيه & الخامات المستخدمة & 5 \\
\hline 0 & نص منر حرير ايزيس أسود & 1 \\
\hline ro & ا متز نل متوسط السمك & r \\
\hline$r$. & ا متر قماش ستان متوسط السمك & r \\
\hline 1 & سوستة & $\varepsilon$ \\
\hline iv & r بكرة خيط مالونيه & 0 \\
\hline 1 & ا متر بيه ستان & 7 \\
\hline r & خيط للتشطيب & 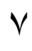 \\
\hline Vr & الإجمالي & \\
\hline
\end{tabular}

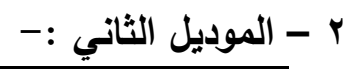

\begin{tabular}{|c|c|c|}
\hline السعر / جنيه & الخامات المستخدمة & 5 \\
\hline r. & نص متز قماش جينز & 1 \\
\hline ro & 1 منز قماش فيسكوز & r \\
\hline 1 & سوستة & r \\
\hline ir & شريط ستان ألوان عرض نص سم للتطريز & $\varepsilon$ \\
\hline r & خيط للتشطيب & 0 \\
\hline vi & الإجمالي & \\
\hline
\end{tabular}

\begin{tabular}{|c|c|c|}
\hline السعر / جنيه & الخامات المستخدمة & 5 \\
\hline$\leqslant 0$ & ه. 1 متر ستان دي شيس & 1 \\
\hline 1 & سوستة & r \\
\hline 9 & خرز وترتر ذهبي & r \\
\hline r & خيط للتشطيب & $\varepsilon$ \\
\hline $0 \wedge$ & الإجمالي & \\
\hline
\end{tabular}

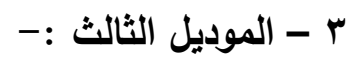


ع - الموديل الرابع :-

\begin{tabular}{|c|c|c|}
\hline السعر / جنيه & الخامات المستخدمة & $\begin{array}{r}5 \\
5\end{array}$ \\
\hline$r$. & 1 1. منز ستان منوسط السمك & 1 \\
\hline 0 & ربع متر ستان منقوش & r \\
\hline ० & ربع منز ستان سادة لون كحلي & $r$ \\
\hline 1 & سوستة & $\varepsilon$ \\
\hline 1 & ا متر بيه ستان & $\circ$ \\
\hline$r$ & نص متر فازلين & 7 \\
\hline r & 1 متر شريط ستان عريض & v \\
\hline r & خيط للنتطيب & $\wedge$ \\
\hline 01 & الإجمالي & \\
\hline
\end{tabular}

ه - الموديل الخامس :-

\begin{tabular}{|c|c|c|}
\hline السعر / جنيه & الخامات المستخدمة & $\begin{array}{r}5 \\
5\end{array}$ \\
\hline r. & 1.0 متر ستان متوسط السمك & 1 \\
\hline 1 & ا متز بيه ستان & r \\
\hline 1 & سوستة & $r$ \\
\hline 1. & ألوان بيجمنت & $\varepsilon$ \\
\hline r & خيط للتشطيب & $\circ$ \\
\hline «0 & الإجمالي & \\
\hline
\end{tabular}

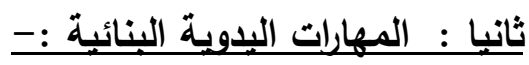

ا 1 - الموديل الأول :-

\begin{tabular}{|c|c|c|}
\hline السعر / جنيه & 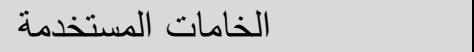 & م \\
\hline v & ربع متر تل أبيض & 1 \\
\hline 0 & نص متر حرير ايزيس & r \\
\hline r. & 1 متر قماش ستان متوسط السمك & r \\
\hline 1 & سوستة & $\varepsilon$ \\
\hline r & r بكرة كتون برليه للكروشيه & 0 \\
\hline r & خيط للتشطيب & 7 \\
\hline Tr & الإجمالي & \\
\hline
\end{tabular}


r - الموديل الثاني :-

\begin{tabular}{|c|c|c|}
\hline السعر / جنيه & الخامات المستخدمة & 5 \\
\hline$\varepsilon$. & 1 متز قماش قطيفة & 1 \\
\hline r. & r شلة خيط صوف للتريكو & r \\
\hline r & خيط للتشطيب & r \\
\hline vr & الإجمالى & \\
\hline
\end{tabular}

r - الموديل الثالث :-

\begin{tabular}{|c|c|c|}
\hline السعر / جنيه & الخامات المستخدمة & 5 \\
\hline 0 . & r متر تل سميك & 1 \\
\hline$\varepsilon$. & 1 ا متر قماش قطن & r \\
\hline rT & r بكرة كتون برليه للنسيج & $r$ \\
\hline r & خيط للتشطيب & $\varepsilon$ \\
\hline 119 & الإجمالي & \\
\hline
\end{tabular}

؟ - الموديل الرابع :-

\begin{tabular}{|c|c|c|}
\hline السعر / جنيه & الخامات المستخدمة & 5 \\
\hline ro & | & 1 \\
\hline r. & 1 متر ستان متوسط السمك & r \\
\hline$r \varepsilon$ & r بكرة ستان عرض ا سم & $r$ \\
\hline r & ربع متر فازلين & $\varepsilon$ \\
\hline 1 & |سوستة & 0 \\
\hline 1 & | متر بيه زهري & 7 \\
\hline r & خيط للتشطيب & $V$ \\
\hline$V V$ & الإجمالي & \\
\hline
\end{tabular}

$$
\text { ه - الموديل الخامس :- }
$$

\begin{tabular}{|c|c|c|}
\hline السعر / جنيه & الخامات المستخدمة & s \\
\hline 7. & ه. 1 متر قماش قطيفة & 1 \\
\hline ro & خرز متوسط الحجم 0 لون & r \\
\hline 1 & سوستة & r \\
\hline r & خيط للتشطيب & $\varepsilon$ \\
\hline$\wedge 9$ & الإجمالى & \\
\hline
\end{tabular}


توصيات البحث :-

ا. استغلال المهارات اليدوية في رفع الجانب الجمالي للملابس والمساهمة في تتشيط الإنتاج الحرفي البسيط.

r. تفعيل دور المؤسسات التعليمية في نشر المهارات والحرف اليدوية، وتشجيعها والمحافظة

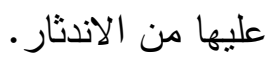

r. تعميق قنوات التواصل بين رجال الصناعة والأعمال والمؤسسات التعليمية لتفعيل الأفكار التي يمكن أن تمثل مشروعات صغيرة للشباب.

ع. الاهتمام بدراسة ملابس الأطفال وما يحتاجه الطفل من الناحية الجمالية والوظيفية وتلبية تلك الاحتياجات.

0. تتجيع إقامة الدورات التدريبية لتعليم المهارات اليدوية المختلفة لتعميم الاستفادة منها.

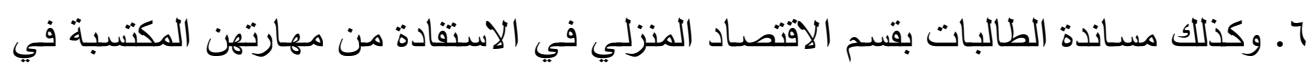
مجال سوق العمل وتفعيل دور الصناعات الصغيرة

V. إثراء المكتبة العربية بدراسة علمية حديثة، تقيد المتخصصين، والدارسين مسنقبلياً في هذا المجال. 
I. إسماعيل شوقي (991 (1)): الفن والتصميم- ط Y - دار نهضة مصر - القاهرة.

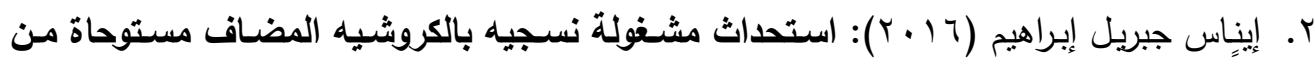

الفن الحديث- رسالة ماجستير - جامعة بنها- كلية تربية نوعيه- قسم التربية الفنية.

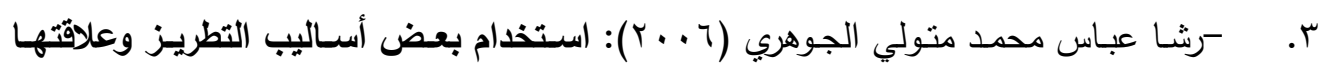

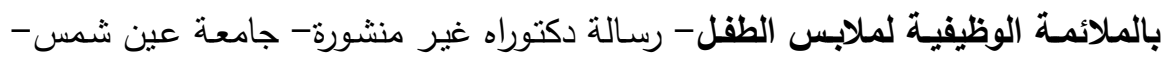
كلبة التربية النوعية- شعبة الاقتصاد المنزلي.

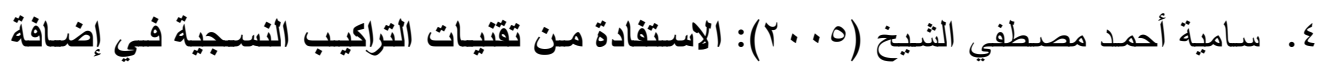
التأثيرات الجمالية لملابس الأطفال - مجلة بحوث في التربية الفنية والفنون -جامعة حلوان

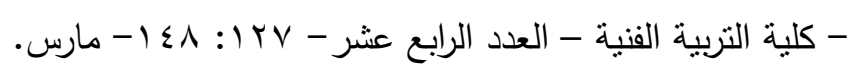

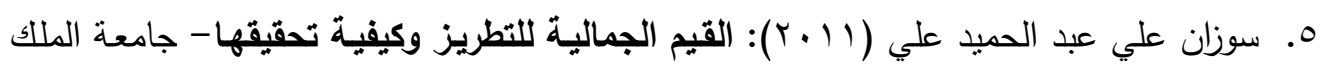

$$
\text { سعود - الطبعة الأولي. }
$$

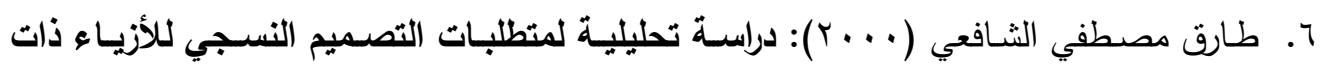

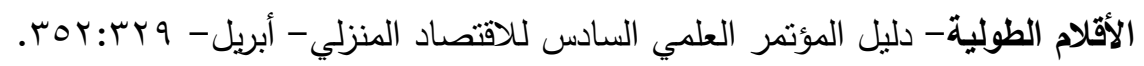

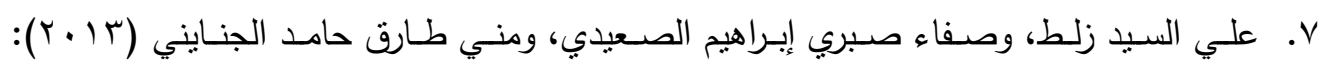
تصميمات زخرفيه مبتكرة مستوحاة من الفن الإسـلامي وأسـاليب تتفيذها علي ملابس

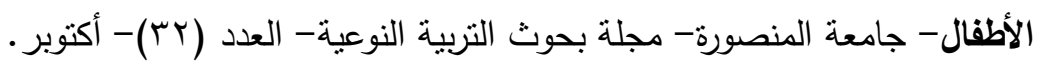

1. عنايات المهدي ( •99 ( )): كل شيء عن فن زخرفة القماش يدوياً- مكتبة ابن سينا.

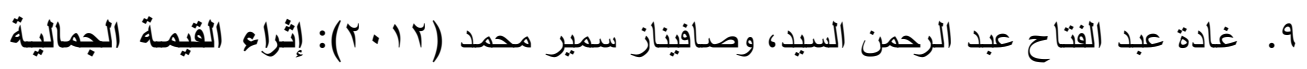
لملابس الأطفال المرحلة الوسطى باستخدام التقتيات المختلفة- مجلة بحوث التربية

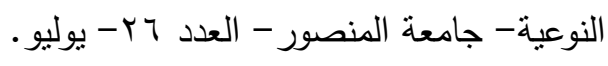

• ا.فاطمة السعيد مدين، وشيماء محمد عامر ناصف (1 ( • ب): استخدام الطباعة في إبراز جماليات الفن الأوريجامي لتصميم وتتفيذ ملابس الأطفال الاستعراضية باستخدام التشكيل على المانيكان - مجلة العمارة وإلقنون - العدد الحادي عثر - الجزء الثاني.

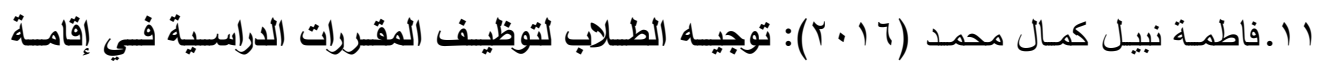
مشروعات صغيرة: مقرر التطريز والكروشيه كنموذجاً- المؤتمر العلمي الثالث الدولي الأول لكلية التربية النوعية جامعة عين شمس: تطوير التعليم النوعي في ضوء الدراسات

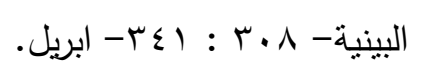

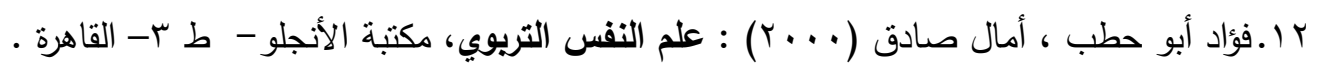




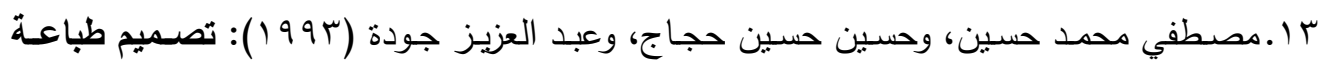
المنسوجات اليدوية -القاهرة- الطبعة الأولي.

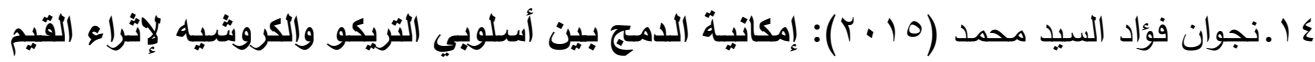

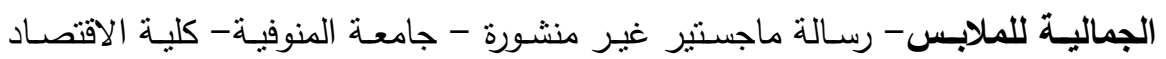
المنزلي- قسم الملابس والنسيج.

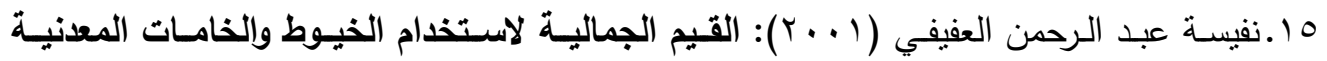

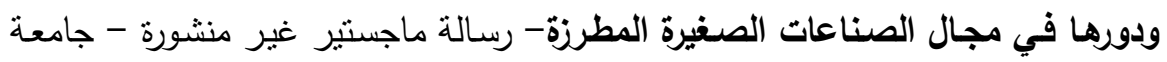

$$
\text { حلوان - كلية الاقتصاد المنزلي - قسم الملابس والنسيج. }
$$

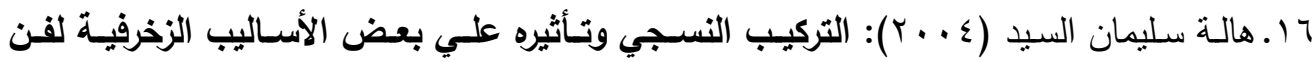

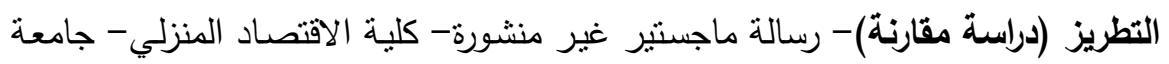

$$
\text { حلوان - قسم الملابس والنسيج. }
$$

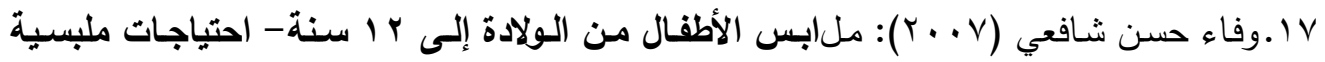

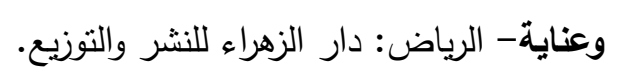

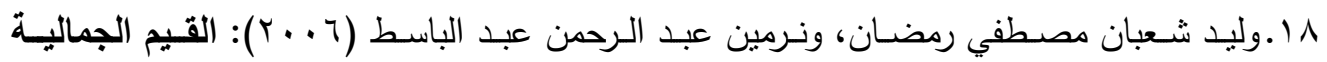

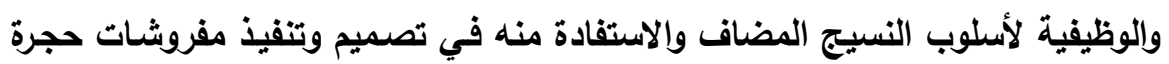
الطقل- مجلة علوم وفنون دراسات وبحوث- جامعة حلوان - المجلد الثامن عشر - العدد

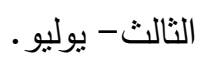

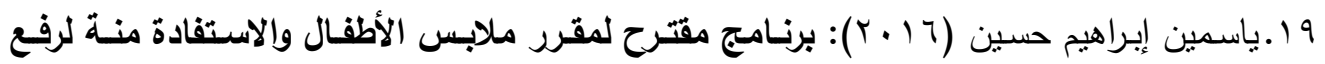

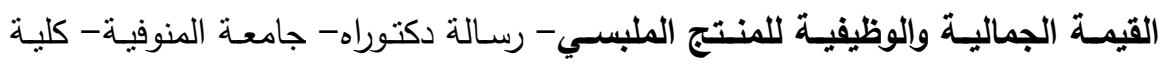

$$
\text { التربية النوعية- قسم الاقتصاد المنزلي. }
$$

20. Reading Teach (2008) : Jornal Clarifying difference between Reading Skills and Reading strategies - Feb.

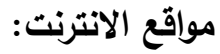
(www.wikipedia.com ) 


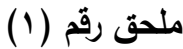

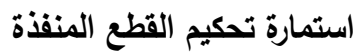

$$
\text { التخصص : الجامعة : }
$$$$
\text { السيد-ة الأستاذ الدكتور }
$$$$
\text { الكلية : }
$$

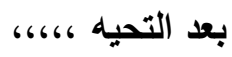

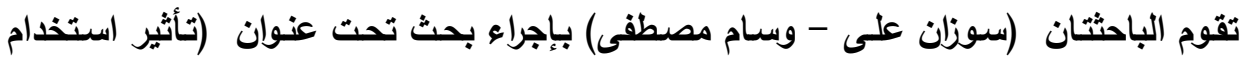

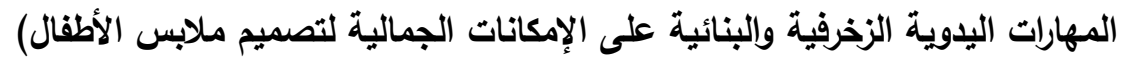

\begin{tabular}{|c|c|c|c|c|c|}
\hline ملاحظات & لا لا أوافق & أوافق إلي حد & أوافق & 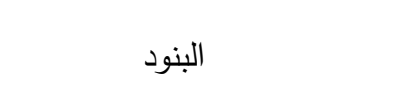 & r \\
\hline & & & & ملائمة الاستبيان لمحاور التقييم & 1 \\
\hline & & & & شمول الاستيان لبنود التقييم & r \\
\hline & & & & دقة صباغة عبارات الاستيان & $r$ \\
\hline & & & & صلاحية الاستيان للنطبيق & $\varepsilon$ \\
\hline
\end{tabular}

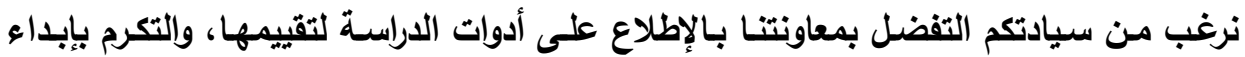

\begin{tabular}{|c|c|c|c|c|}
\hline ضعيف & متوسط & ممتاز & البنود & م \\
\hline \multicolumn{5}{|c|}{ المحور الأول: تأثير تطبيق المهارة علي القيمة الجمالية للتصميم الملبسي } \\
\hline & & & أسلوب تتفيذ المهارة اليدوية & 1 \\
\hline & & & ملائمة الخامات المستخدمة في التتفيذ & r \\
\hline & & & التصميم المستخدم في التنفيذ & $r$ \\
\hline & & & ملائمة الألوان المستخدمة في التنفيذ & $\varepsilon$ \\
\hline & & & قيمة المنتج الجمالية. & • \\
\hline & & & أسلوب إنهاء القطعة & 1 \\
\hline \multicolumn{5}{|c|}{ المحور الثاني: تأثير تطبيق المهارة علي الاداء الوظيفي للمنتج الملبسي } \\
\hline & & & أسلوب التنفيذ المستخدم مناسب للفترة العمرية & 1 \\
\hline & & & أسلوب التتفيذ المستخدم يوفر الراحة للطفل & $r$ \\
\hline & & & أسلوب التنفيذ المستخدم لا يمتل خطر علي الطفل & $r$ \\
\hline & & & أسلوب التنفيذ المستخدم سهل العناية به & $\varepsilon$ \\
\hline \multicolumn{5}{|c|}{ المحور الثالث: مدي مناسبة المنتج للمرحلة العمرية. } \\
\hline & & & ملائمة المهارة المستخدمة للطفل في مرحلة الطفولة المبكرة. & 1 \\
\hline & & & ملائمة الألوان المستخدمة للطفل في مرحلة الطفولة المبكرة. & $r$ \\
\hline & & & ملائمة الخامات المستخذمة للطفل في مرحلة الطفولة المبكرة. & $r$ \\
\hline & & & ملائمة الثكل العام للمنتج وتفضيله له & $\varepsilon$ \\
\hline
\end{tabular}
الرأي في النقاط التالية من خلال وضع علامة (ل ) في المكان الذي يمثل إجابتك. 
ملحق رقم(r)

استمارة تقييم آراء المستهلكات ملمات

\begin{tabular}{|c|c|c|c|c|}
\hline 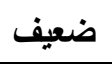 & 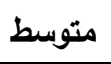 & 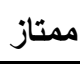 & 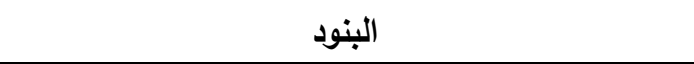 & م \\
\hline & & & يتوفر فى التصميم الجودة فى التنفيذ والتشطيب. & 1 \\
\hline & & & يتماشى التصمير مع الموضة السائدة لأزياء الأطفال. & $r$ \\
\hline & & & يحقق التصميم السهولة في الارتداء. & $r$ \\
\hline & & & البعضوافر الملائمـة للألوان المنفذ بها التصميم مـع بعضها & $\varepsilon$ \\
\hline & & & تتوافر فى التصميم الراحة فى الارتداء. & $\bullet$ \\
\hline & & & يحقق التصميم قدرة الطفل على مزاولة أنشطته المختلفة. & 7 \\
\hline & & & يحقق التصميم الأمان أثثاء الارتداء للطفل. & $\mathrm{v}$ \\
\hline & & & الارتداءور. فى التصـيم تحقيق ثقة الطفل فى نفسـه عند & $\wedge$ \\
\hline & & & يحقق التصميم التكيف للطفل مع أقرانه. & 9 \\
\hline & & & يلائم التصميم المرحلة العمرية المصمم من اجلها. & 1 \\
\hline & & & يحقق التصميم إمكانية تسويق المنتج. & 1 \\
\hline & & & 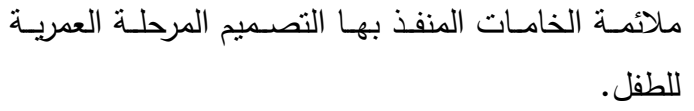 & $\begin{array}{c}1 \\
r\end{array}$ \\
\hline
\end{tabular}




\section{ملحق رقم (r)}

أسماء السادة المحكمين

\begin{tabular}{|c|c|c|}
\hline 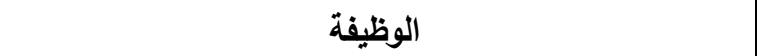 & 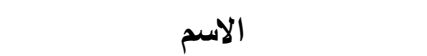 & s \\
\hline حلوان أستاذ الملابس والنسيج - كليـة الاقتصـاد المنزلي - جامعـة & ا.د/ وليد شعبان مصطفى & 1 \\
\hline حلوان أستاذ الملابس والنسيج - كليـة الاقتصـاد المنزلي - جامعـة & ا.د/ حاتم الرفاعي & $r$ \\
\hline شمس أستاذ الملابس والنسيج - كلية التربية النوعية -جامعة عين & 1.د/ هبة عاصم & $r$ \\
\hline أسنـاذ الملابسس والنسـيج - كليـة التربيـة النوعيـة - جامعـة & ا.د// شا عباس الجوهري & $\varepsilon$ \\
\hline أسفتاذ الملابسس والنسـيج - كليـة التربيـة النوعيـة -جامعـة & ا.د/ رياب محمد السيد & 0 \\
\hline أسنـاذ الملابس والنسيج - كليـة التزبيـة النوعيـة - جامعـة & ا.د/ أمل عبد السميع مأمون & 9 \\
\hline أستاذ الملابس والنسيج المساعد - كلية الاقتصاد المنزلي - & ا.م.د/ دعاء محمد راغب سالمان & $v$ \\
\hline أستاذ الملابس والنسيج المساعد - كلية الاقتصاد المنزلي - & ا.م .د/ رحاب محمد على & $\wedge$ \\
\hline مدرس الملابس والنسيج- كلية التربية النوعية - جامعة حلوان & د منصورة سليمان & 9 \\
\hline
\end{tabular}

